د. رجب أحمد عطا محمد

\title{
تأهيل مديري مدارس التربية الخاصة بمحافظة البحر الأحمر في دمي مدي ضوع محددات الرشاقة الإستراتيجية
}

$$
\text { إعـــــداد }
$$

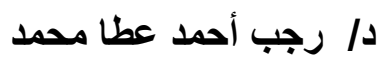

مدرس التربية المقارنة والإدارة التعليمية

كلية التربية بالغردقة - جامعة الإدة جنوب الواديمية

الملخص:

تمثلت مشكلة البحث الحالي في السؤال الرئيس" ما التصور المقترح لتأهيل مديري مدارس التربية الخاصة بمحافظة البحر الأحمر في ضوء محددات الرشاقة الاستراتيجية؟، ولقد هدف البحث إلي التعرف علي: التعرف على الأسس النظرية والفكرية لمتغير الرشاقة الاستراتيجية بالمؤسسة التعليمية في الأدبيات الإدارية المعاصرة، وتحديد الواقع الفعلي لتوافر محددات الرشاقة الاستراتيجية لدي مديري مدارس التربية الخاصة بمحافظة البحر الأحمر من وجهة نظر المعلمين والعاملين، مع إمكانية التوصل إلي تصور مقترح لتأهيل مديري مدارس التربية الخاصة بمحافظة البحر الأحمر في ضوء محددات الرشاقة الاستراتيجية ، ولتحقيق أهداف الدراسة نم استخدام المنهج الوصفي لملاءمته لطبيعة الموضوع وتكونت عينة البحث من(· (ا) فردًا ما بين معلمين و عاملين بمدارس التربية الخاصة بمحافظة البحر الأحمر، واعتمد الباحث علي استبيان لقياس تو افر محددات الرشاقة الاستر اتيجية( الحساسية الاستر اتيجية - سيولة الموارد- وحدة القيادة- التكنولوجيا)، وتوصل البحث إلي أن المتوسط الكلي لمحددات الرشاقة الاستراتيجية لدي مديري مدارس التربية الخاصة جاءت بدرجة التهادية

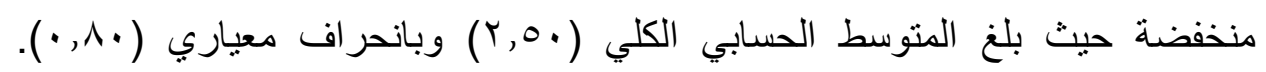
الكلمات المفتاحية: تأهيل، الرشاقة الاستراتيجية. 
تأهيل مديري مدارس التربية الخاصة بحافظة البحر الأحمر في ضوء محدات الرشاقة الإستراتيجية

Qualifying Red Sea special Education

schools' directors in light of strategic agility

determinants

Abstract:

The problem of the present study could be stated in the main question "what is the proposed scenario for qualifying Red Sea special Education schools' directors in light of strategic agility determinants?". The main objective of the study was to identify the theoretical and intellectual foundations of strategic agility in the Educational institution through contemporary administrative literature, and determine the actual reality of the availability of the strategic agility determinants of Red Sea special Education schools' directors from the point of view of both teachers and workers. In addition to the possibility of reaching a proposed scenario for qualifying Red Sea special Education schools' directors in light of strategic agility determinants. The descrptive approach was used to achieve the objectives of the study for its convenience to the nature of the topic. The study sample consisted of 130 individuals, including teachers and workers in Red Sea special Education schools. The researcher relied on a questionnaire to measure the determinants of strategic agility (strategic sensitivity, fluidity of resources, command unit and technology). The study found that the overall average of strategic agility determinants came with a low level, where the overall mean was 2.5, with a standard deviation of .80.Key words: Strategic agility, Qualifying. 
د. رجب أحمد عطا محمد

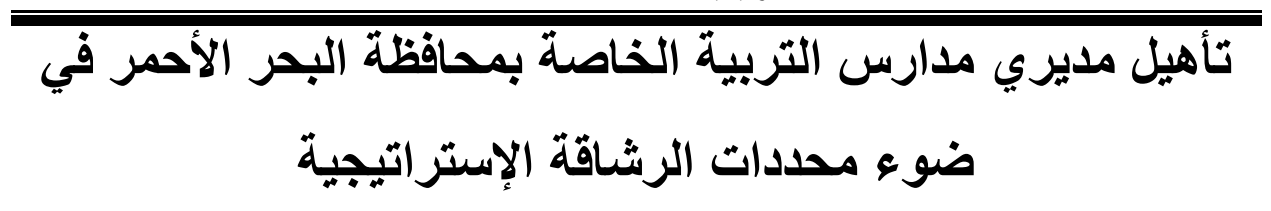

$$
\text { إعـــــداد }
$$

د/ رجب أحمد عطا محمد

مدرس التربية المقارنة والإدارة التعليمبة ولية

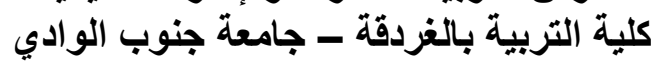

أولاً الإطار العام للبحث

مقدمة:

تميزت الدول المتقدمة في الوقت الحاضر بنهضة شاملة في إعادة هيكلة الجهاز

الإداري علي أسس علمية في ظل الانفجار المعرفي الهائل والاقتحام التقني الكبير؛ ومع هذا التطور بدأت متطلبات الحياة العصرية نشكل عبئا ثقيلا على إدارة المؤسسات التربوية حيث يتوقف نجاح المؤسسة التعليمية على مدى امـتلاك هذه الإدارة العديد من الكفايات المهنية التي تمكنها من أداء مهامها على الوجه الأكمـل.

ووفقا لـ Robert E. Morgan \& Kelly Page $(2008,161)$

مفتاح النجاح في بيئة أعمال ديناميكية وسريعة التغيير الرشاقة الاستراتيجية والتي تعرف بأنها القدرة على دعم وفي بعض الأحيان إحداث تغييرات مفاجئة من أجل الاستفادة من فرص السوق المتغيرة. ولا تعني الرشاقة الإستراتيجية عدم وجود إستراتيجية، ولكنها تركز على التفكير الإستر اتيجي والرؤية الواضحة بدلاً من التخطيط الاستر اتيجي، بالإضافة إلى مفهوم مشترك لتطوير الإستر اتيجية وتنفيذها بدلاً من الفصل

بينهما (Marit Santala,2009,36)

و على الرغم من أن الإستراتيجية والتوجه الاستراتيجي لا يزالان مهمين كما كان عليهما من قبل، في بيئة الأعمال سريعة التغير اليوم، يجب استبدال التخطيط الاستر اتيجي طويل الأجل والإستر اتيجية الصسارمة بالرشاقة الإستر اتيجية.

العدد الخامس والاربعون (الجزء الاول) ا r.r.

(185)

جلة كلية التربية- جامعة عين شمس 
تأهيل مديري مدارس التربية الخاصة بحافظة البحر الأحمر في ضوء محددات الرشاقة الإستراتيجية

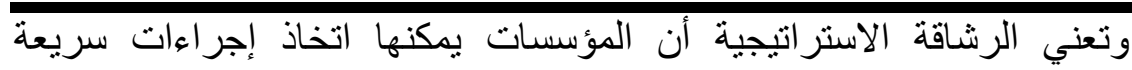

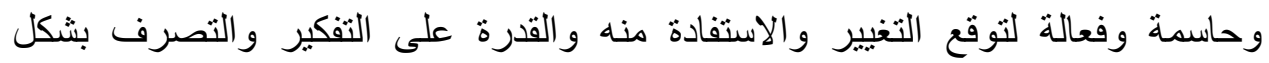
مختلف، والتكيف المستمر والتوجه الاستراتيجي للأعمال Yves Doz\&Mikko) Kosonen, 2008: 6)

ويمكن اعتبار الرشاقة الإستراتيجية كففوم يتكون من عنصرين: الاستجابة

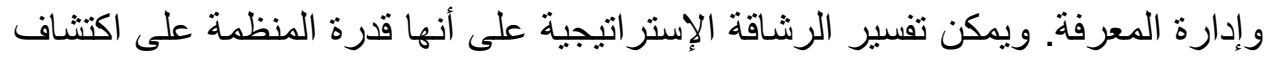

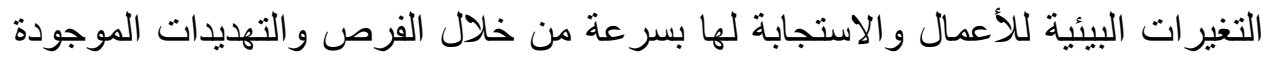
في بيئة الأعمال، وتقديم استجابة سريعة من خلال إعادة تجميع الموارد والعمليات و الاستراتيجيات (Arokodare, Asikhia and Makinde,2019,4) . وتخلق الرشاقة الاستر اتيجية قدرة تنظيمية على التكيف والتكيف بشكل مستمر وبشكل مناسب في الوقت المناسب مع الاتجاه الاستراتيجي للمؤسسة في تحقيق الأداء الجيد، وفي بيئة الأعمال بالقرن الحادي والعشرين، سيؤدي تبني الرشاقة الاستراتيجية إلى تعزيز الأداء المستمر والتعديل المناسب للمؤسسة نحو بيئة الأعمال الديناميكية الإنية الإنية والتككيف في الوقت المناسب. Onyema .E. Ofoegbu\& Paul Ayobami) René Rohrbeck \& Menes Etingue ويثير ، Akanbi,2012,153) Kum $(2018,107)$

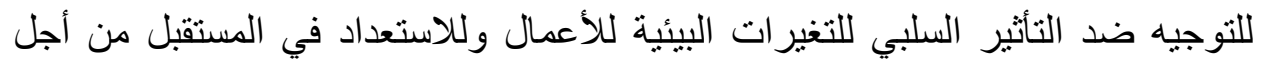

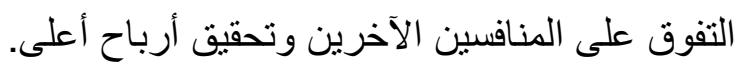
وتعد الإدارة المدرسية مكونا أساسيا من مكونات النظام التعليمي, فهي التي ترسم الترئ

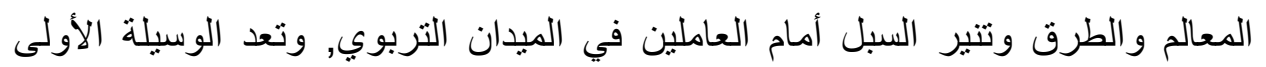
والأخيرة في تنفيذ الأهداف والسياسات, كما أن لها أهمية في تنمية شخصية الكنعلم من المنان جميع النواحي العقلية والوجدانية والجسمية, وتتمية المجتمع الذي تعمل فيه الددرسة

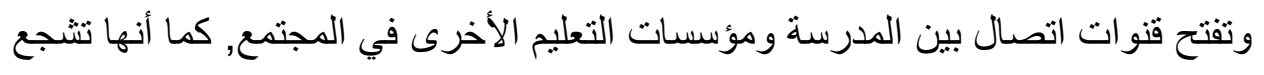


د. رجب أحمد عطا محمد

وتساعد على تنمية التفكير ألابتكاري لاى المعلمين و الطالب, وتنمي القدرة لديهم على التقويم الذاتي واستخدام التفكير العلمي لحل المشكلات داخل وخارج المدرسة Ali Bin)

Abdulreaha Al Lawati,2018,77)

وتتطلب طبيعة مدارس ذوي الاحتياجات الخاصة مزيدا من الجهود المبذولة من قبل

الإدارة المدرسية، حيث أنها ضرورية لجميع أولئك الأفراد الذين يتعرضون لخطر معاناة صعوبات مستمرة في التعليم والتكيف في ظل الفرص التعليمية العادية المتاحة لأقر انهم العاديين (أمنية إسماعيل الكنيسي، 9 . . ب، 00)، لذا يري عبد الغني أحمد عبود

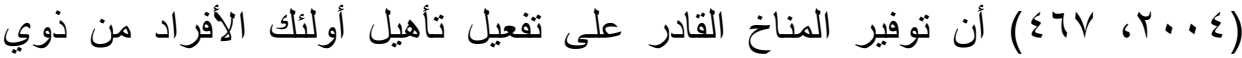
الاحتياجات الخاصة تقع على عاتق الإدارة التي لابد لها أن تكون واعية وفاعلة ومتطورة. وخاصة أن الإدارة إحدى التنظيمات المدرسية الهامة التي لها دوراً أساسياً في تحقيق أهداف العملية التعليمية داخل المدرسة، والتي تسعي إلى توفير وتهيئة جميع الأجو اء و المتطلبات النفسية و الاجتماعية والمادية اللازمة لحدوث عملتي التعلم والتعليم داخل الصف بصورة فعالة وناجحة. لذلك تحتاج مدارس التربية الخاصة إلى إدارة علمية منظمة تقوم علي أسس علمية تسعي إلي التنسيق بين جميع أفراد العملية التربوية والمتمثلة في الوظائف الإدارية

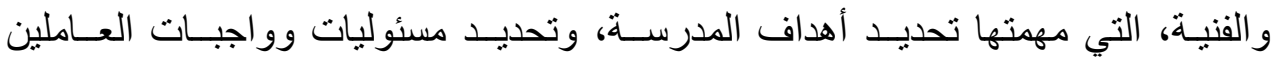
فيه، و الاتصال والتسيق مع أولياء الأمور، ومع الجهات الرسمية وغير الرسمية، فينبغي

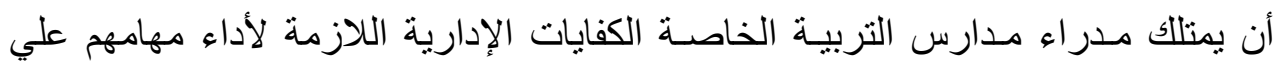

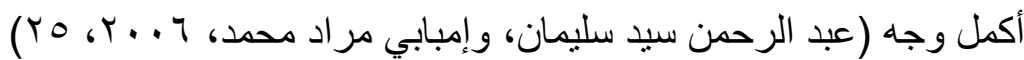
ولقد تغيرت أدوار مدير المدرسة واتسع مجالها وخاصة فيما يتعلق بمدارس التربية الخاصة وأهميتها للمجتمع و الأسرة المصرية، فلم تعد مجرد عملية روتينية تهدف إلى تسيير شؤون المدرسة سيراً رتيباً وفق قواعد وتعليمات معينة نركز على النواحي الإدارية، بل أصبحت تعنى بكل ما يتصل بالعملية التربوية من طلبة ومدرسين، وطر ائق 
تأهيل مديني مدارس التربية الخاصة بحافظة البحر الأحمر في ضوء محددات الرشاقة الإستراتيجية

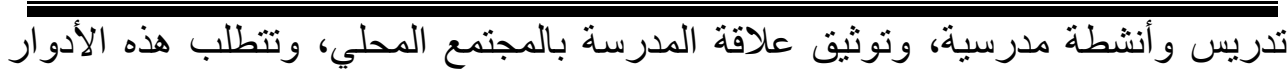
المتجددة لدديري المدارس قدر كبير من المرونة والفاعلية من خلال تبني الرشاقة الإستراتيجية كمدخل لتطوير الأداء القيادي و الإداري بمؤسسات التربية الخاصة وقد نال مجال رعاية ذوي الاحتياجات الخاصة اهتماماً بالغاً في السنوات الأخيرة، ويرجع ذلك إلى اللى

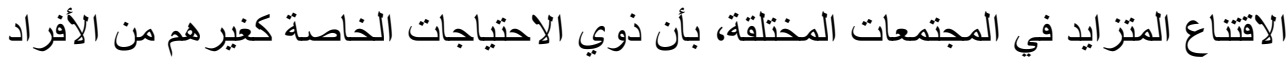

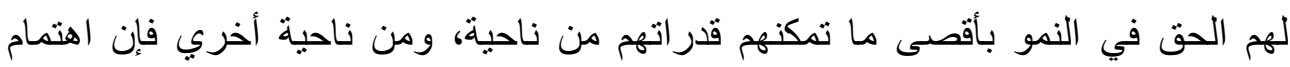
المجتمعات بفئات ذوي الاحتياجات الخاصة برتبط بتغير النظرة المجتمعية إلي هؤلاء الأطفال، والتحول من اعتبار هم عالة اقتصادية علي مجتمعاتهم إلي النظر إليهم كجزء من الثروة البشرية مما يحتم تتمية هذه الثروة و الاستفادة منهم إلي أقصي درجة ممكنة.

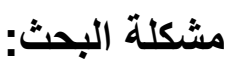

لقد اهتمت مصر برعاية أطفالها المعوقين تحقيقاً لمبدأ "التربية للجميع"فقد كفل الدستور المصري حق التعليم للمواطنين جميعا دون تفرقة أو تمييز لسوي على معوق،

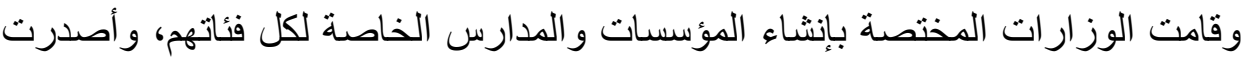
القرارات و اللو ائح اللازمة لتنظيم العمل بها.

وتسـعي إدارة مـدارس التربيـة الخاصـة بصدـر إلى تحقيق هـدف عـام

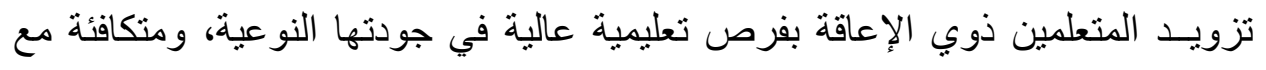
أقرانهم من غير ذوي الإعاقة، ودمج ذوي الإعاقة البسيطة بجميع مدارس التعليم قبل

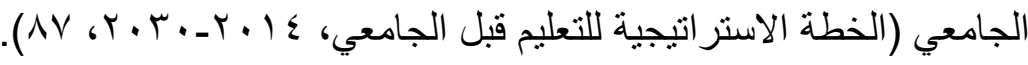
إن مـدارس التربيـة الخاصـة لا يمكـن أن تحقق أهدافها دون الإدارة

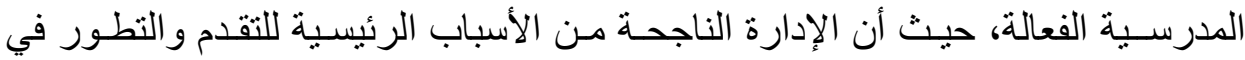

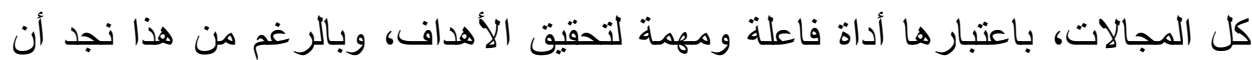
هنالك جوانب قصور في إدارة مدارس التربية الخاصة ومن مظاهر هذا القصور ما تأكده

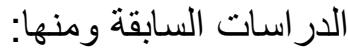


د. رجب أحمد عطا محمد

ما توصلت إليه دراسة باسم سليمان ( ( ا.ب) إلي ضعف قدرة المديرين بمدارس التربية الخاصة على التنبؤ بالمتغيرات الخارجية التي تحيط مدارسهم، و على صياغة الرؤية والرسالة والأهداف الإستراتيجية لمدارسهم مما يعيق تجويد الأداء بمدارسهم وتطوير ها.كما تشير دراسة رحاب كريم (Y) (Y) إلى أن مدارس التربية الخاصة في مصر من قلة وعي بعض المديرين بالتشريعات و القوانين واللوائح المنظمة لمدارس التربية الخاصة. وأشارت دراسة ريهام عبد الحمبد علي شبيب (ع ا ـ إ) إلى أن مدارس التربية الخاصة بمصر تتصف بالروتينية والإهمال و المحابـاة، والخوف المتزايـد مـن تحمل المسئولية والإلقاء بها على كاهل الآخرين، قلة تلقي أي بـر امج تدريبيـة للإعداد لوظيفـة مدير مدرسـة تربيـة خاصسـة، وعدم تلقي برامج تدريبيـة فعالـة تخصصسية لتتميـة مديري مـدارس وفصـول التربيـة الخاصـة إدارياً وفنياً ومهنياً. وتري دراسة إيمان أحمد حسن همام(T · . †) من خلال النتائج التي توصلت إليها أنه لا يوجد توصيف إداري يوضتح اختصاصات ومسئوليات مديري مدارس التربية الخاصة، إنما يتم إتباع القرارات و القوانين الوزارية التي توضح أدوار ومسئوليات مديري مدارس التعليم العام، مع إغفال طبيعة مجال التربية الخاصة، كما أن السلطات المتاحة لمديري مدارس التربية الخاصة لا تتناسب مع مسئولياتهم، مما يؤدي إلى ظهور كثير من المشاكل وتؤثر علي قدرة مدير المدرسة وأداءه الإداري والفني.

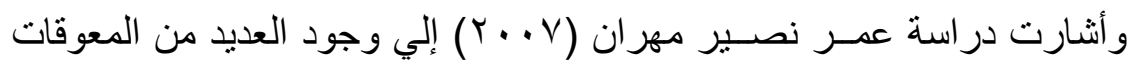
التي تو اجه إدارة مدرسة التربية الخاصة في مصر تحد من قدرتها علي تحقيق رسالتها ومن هذه المعوقات: مركزية الإدارة، فليس لإدارة مدارس التربية الخاصة الحق في اتخاذ قرارات تعليمية تخص المدرسة، كما لا يحق لإدارة المدرسة وضع معايير خاصة لاختيار العاملين بها، وقصــور نظـام تـدريب المعلمـين و المــديرين لهـذا النـوع مـن المـدارس، وضعف القرارات المتخذة علي مستوي المدرسة لعدم إعداد مدير المدرسة 
تأهيل مديزي مدارس التربية الخاصة بمحافظة البحر الأحمر في ضوء محددات الرشاقة الإستراتيجية

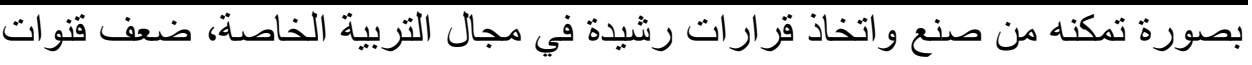

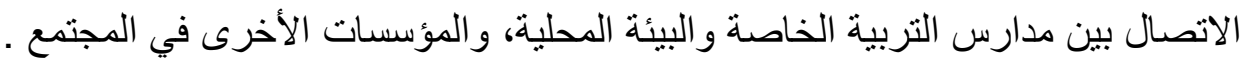

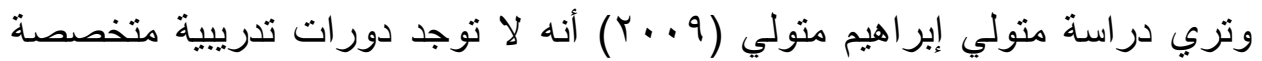
للمديرين في مجال التربية الخاصة، وعدم اتسـاق أهداف تدريب مديري مدارس دارس

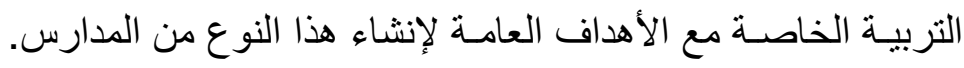

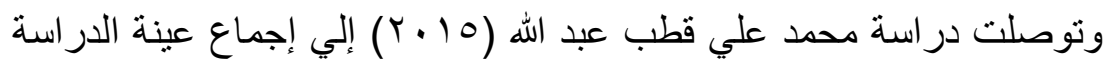
المنمثلة في معلمي التربية الخاصة والإداريين والأخصائيين بمدارس التربية الخاصة علي الحاجة الماسة لتحسين مدارس التربية الخاصة بمصر لجميع عناصر المدرسة من التربن

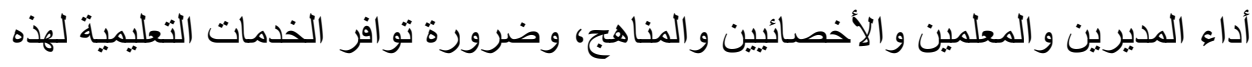

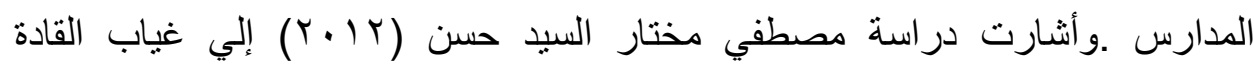

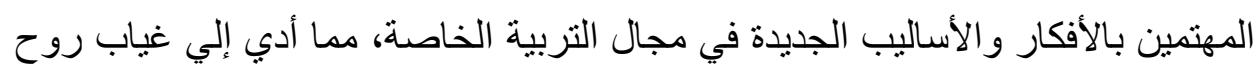
الفريق داخل الددرسة وندرة التثاور و التعاون في إدارة الددرسة.

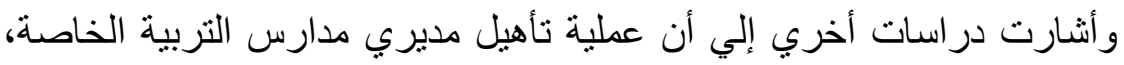

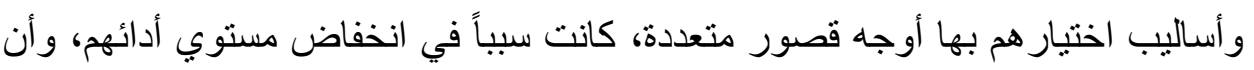
نقص تأهيل مديري مدارس التربية الخاصة، وقصور أساليب اختيار هم ، ومن ثم قصور

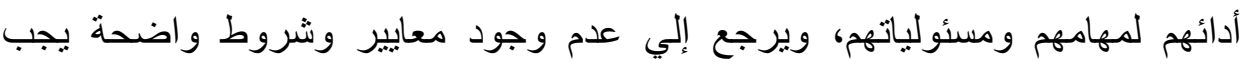
مراعاتها والالتزام بها في اختيار مديري مدارس التربية الخاصة، وفي الترخيص لهم

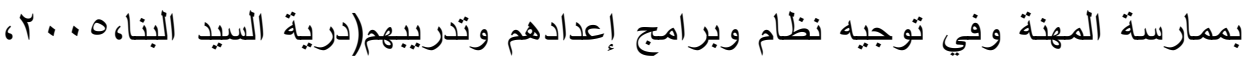

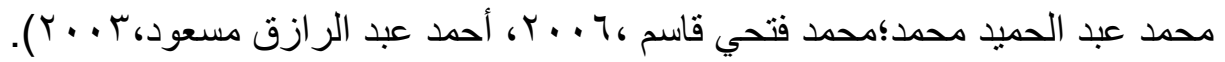

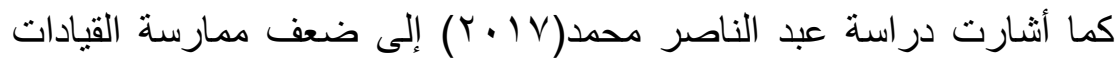
المدرسية لدور هم في مساندة المعلمين ودعمهم وحفز هم، وضعف مهارات الاتصال بين أعضاء الإدارة المدرسية، وضعف إطلاع الأفر اد على المستحدثات والاتجاهات التربوية المعاصرة في مجال التربية الخاصة وإدارتها. 
ويستتتج الباحث من خلال هذه الدراسات السابقة في مجـال إدارة مدارس ردم التربيـة الخاصــة أن إدارة هذه المدارس تواجهها كثير من المشكلات، وأن معظم مديري المدارس المسئولين عن فاعلية وجودة الأداء الإداري في حاجة إلى المزيد من التدريب و التأهيل لتحسين المخرجات. من خلال تبني محددات الرشاقة الاستر اتيجية. ومن ثم بسعى البحث الحالي إلى الإجابة على الأسئلة التالية:

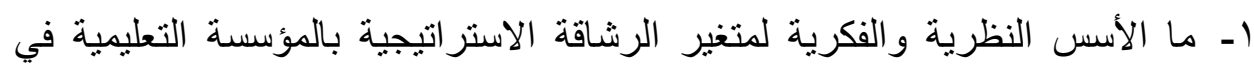
الأدبيات الإدارية المعاصرة

r- ما طبيعة دور مديري مدارس التربية الخاصة نظريا؟ r- ما واقع توافر محددات الرشاقة الاستراتيجية لدي مديري مدارس التربية الخاصة بمحافظة البحر الأحمر من وجهة نظر المعلمين و العاملين؟

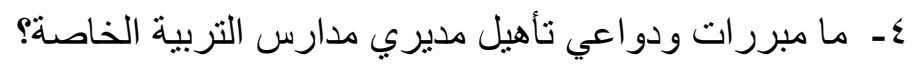
هـ ما التصور المقترح لتأهيل مديري مدارس التربية الخاصة بمحافظة البحر الأحمر

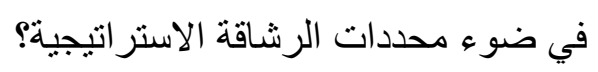
أهداف البحث: - 2 - 2

هدف البحث التوصل إلى تصور مقترح لتأهيل مديري مدارس التربية الخاصة بمحافظة البحر الأحمر، وينبثق من هذا الهدف الرئيسي الأهداف الفرعية التالية:

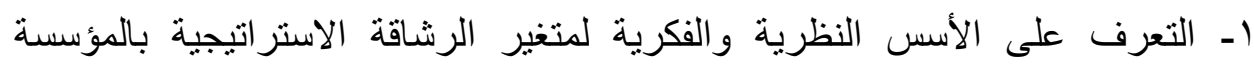
التعليمية في الأدبيات الإدارية المعاصرة.

r- التعرف على طبيعة دور مديري مدارس التربية الخاصة نظريا. r- الكثف على واقع تو افر محددات الرشاقة الاستر اتيجية لاي مديري مدارس التربية الخاصة بمحافظة البحر الأحمر من وجهة نظر المعلمين والعاملين. عـ - الكثف عن مبررات ودو اعي تأهيل مديري مدارس التربية الخاصة. 


\section{تأهيل مديري مدارس التربية الخاصة بمحافظة البحر الأحمر في ضوء محددات الرشاقة الإستراتيجية}

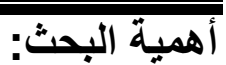

يكتسب البحث أهمية من خلال ما يلي:

ـ الأهمية النظرية: حيث يقدم إطار نظري عن الأسس الفكرية لمتغير الرشاقة الاستراتيجية، وطبيعة دور مديري مدارس التربية الخاصة، وكذلك أهم مبررات ودواعي تأهيل مديري مدارس التربية الخاصة لمواكبة التوجهات التربوية المعاصرة التي تدعو أهمية تحسين وتطوير أداء مديري التربية الخاصة لتحقيق الفاعلية التنظيمية لهذه المدارس. ـ الأهمية التطبيقية: يمكن أن بضيف البحث إلى العمل التربوي و التعليمي تصور مقترح يمكن الاعتماد عليها لتحسين الواقع التنظيمي والفني لمدارس التربية الخاصة لزيادة قدرنها على التوافق مع المتغيرات المعاصرة في أدوار مديري المدارس وخاصة مدارس التربية الخاصة. وتوجيه أنظار المسئولين بوزارة التربية و التعليم إلى أن نجاح الإدارة المدرسية بمدارس التربية الخاصة في تحقيق أهدافها يثوقف على وجود مدير تم إعداده وتدريبه للتعامل الفوري مع المو اقف المختلفة التي تطلبها منـه إدارتـه لمدرسته، وتوضيح التحديات و الدواعي التى تؤكد للمسئولين بوزارة التربية والتعليم على ضرورة تبنى مداخل ادارية حديثة أكثر ملائمة لتطوير أداء مديري مدارس التربية الخاصة.

\section{منهج البحث:}

استخدم البحث المنهج الوصفي باعتباره أكثر المناهج الملائمة ولكونـه المنهج المناسـب لدراسـة الظواهر الاجتماعية والإنسانية، من خلال محاولة الوصول إلي

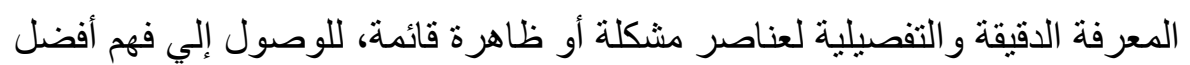
وأدق أو وضع السياسات والإجراءات المستقبلية الخاصة بها(محمد سرحان

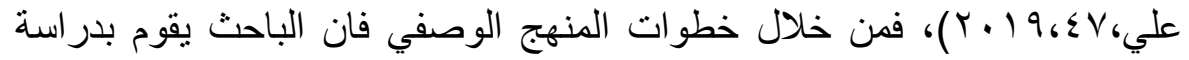
الأسس النظرية و الفكرية لمتغير الرشاقة الاستر اتيجية بالمؤسسة التعليمية و أهميتها 
د. رجب أحمد عطا محمد

ومحدداتها ومجالاتها و إجر اءات تطبيقها بالمدارس في الأدبيات الإدارية المعاصرة، وأهمية طبيعة دور مديري مدارس التربية الخاصة وذلك بجمع البيانات من الأدبيات والدراسات السابقة المرتبطة بهدف تكوين خليفة نظرية كافية حول متغيرات الدراسة وطبيعتها، كما تم إعداد استبانة لهذا الغرض للحصول علي المعلومات المطلوبة عن مدي توافر محددات الرشاقة الاستر اتيجية بمدارس التربية الخاصة في محافظة البحر الأحمر. كما تم استخدام برنـامج التحليل الإحصائي (SPSS) في تفريغ وتحليل الاستبانة. حدود البحث:

اتساقاً مع أهداف البحث تم تحديد حدود البحث على النحو التالي: ا ـ الحدود الموضوعية: اقتصر البحث علي تقصي مستوي الرشاقة الاستر اتيجية بمدارس التربية الخاصة من حيث (الحساسية الاستراتيجية، وحدة الفريق، سيولة الموارد، التكنولوجيا) ץ- الحدود البثرية: اعتمد البحث على استطلاع آراء المعلمين والعاملين في مدارس التربية الخاصة بمحافظة البحر الأحمر حول محددات الرشاقة الاستر اتيجية ومدي تو افر ها لدي مديري المدارس. لأن المعلمين و العاملين هم اكثر احتكاكا بمديري المدارس ولديه القدرة علي تقييم أداء مديري المدارس سو اء من النواحي التعليمية أو الإدارية . بـ الحدود المكانية: يثمل البحث مدارس التربية الخاصة بمدن محافظة البحر الأحمر (الغردقة-رأس غارب - القصبر - سفاجا). ع - الحدود الزمنية: تم تطبيق الجزء المبداني خلال الفصل الدراسي الأول من العام

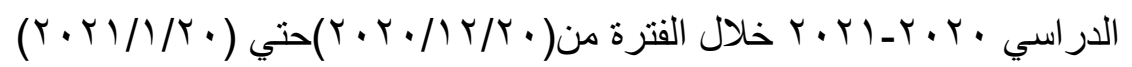


تأهيل مديزي مدارس التربية الخاصة بمحافظة البحر الأحمر في ضوء محددات الرشاقة الإستراتيجية



يرتكز البحث على المصطلحات التالية:

التأهيل (Rehabilitation)

ويقصد به نطوير المهارات القيادية والإدارية لفئة الإدارة العليا بهدف النتأثثير على نوعيات السلوك لدي العاملين بتوجيهها لخدمة العميل وتحسين قدر اتهم في مجال

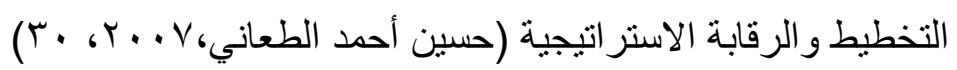

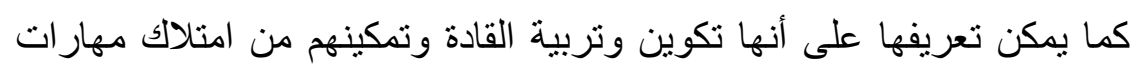
وقدرات فنية وتربوية مع التجديد والتحديث المستمر للكفاءات والمهارات والقدرات

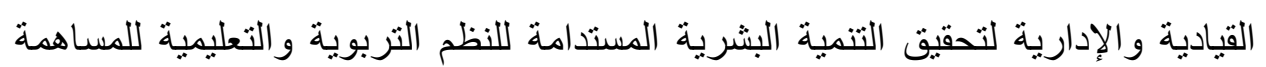

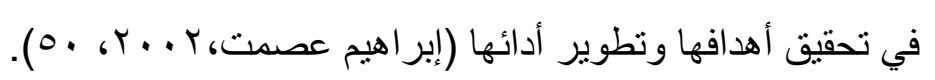

ويقصد بالتأهيل في البحث: إعداد وتجهيز كادر من المديرين ذي قدرة وكفاءة لتحمل أعباء الإدارة المدرسية، ويقود المدرسة بأسلوب إداري متميز من خلال التأثير في

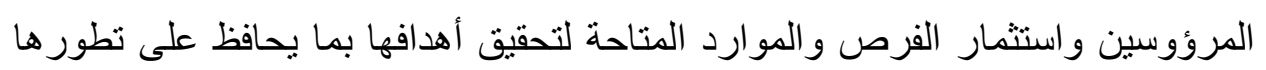
واستمر ارها دون التأثر عند التغيير.

\section{التربية الخاصة: (Special Education)}

ويقصد بها تقديم وتنسيق ومتابعة مجموعة شاملة من الممارسات والخبرات

ذات الصلة بالنواحي العملية والتعليمية والخدمات المساندة لتلاميذ ذوي الاحتياجات

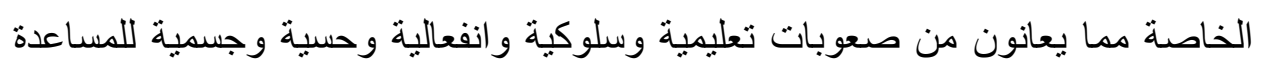

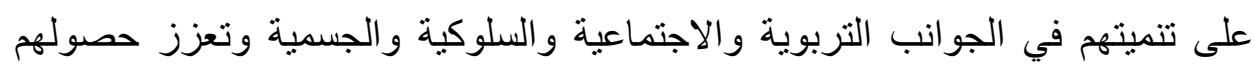

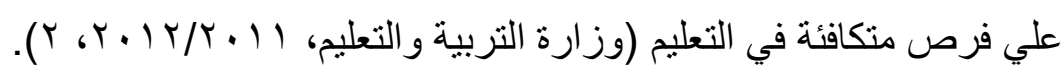
ويقصد بمدارس التربية الخاصة في البحث هي المدارس التي تشرف عليها وزارة التربية والتعليم المصرية وتقدم مجموعة من البرامج والخطط والاستر اتيجيات 
د. رجب أحمد عطا محمد

المصممة لتلبية الاحتياجات الخاصة للأطفال غي العاديين ونشمل خدمات مباشرة وغير مباشرة وبر امج تربوية وتعليمية متخصصة لقئات من الأفر اد غير العاديين.

الرشاقة الاستراتيجية (Strategic agility)

يعتبر مفهوم الرشاقة الاستر اتيجية أحد المفاهيم الحديثة في علم الإدارة، وهي سمة مميزة للمنظمات المعاصرة لما لها من تأثتر كبير على وضوح المنظمات وملكيتها للسر عة والاقة في تفوق منافسيها. ويقصد بها القدرة على تعديل استراتيجية المنظمة بشكل ديناميكي في بيئة أعمال متغيرة؛ يتم تحقيق ذلك من خلال المراقبة المستمرة للبيئة الداخلية والخارجية للمؤسسة، وكذلك التكيف مع احتياجات العملاء دون التخلي عن رؤية المنظمة (Yves) Mary Yoko دوفقًا Doz\&Mikko Kosonen,2008,52) Brannen\&Yves Doz قرارات حقيقية في الوقت المناسب وكما هو مطلوب لتغيير الأسواق والظروف الاستر اتيجية. علاوة على ذلك، حدد Narendra Kumar(2017 الرشاقة الاستر اتيجية بأنها القدرة على التحرك بسرعة وسهولة. وهي سرعة الاستجابة والقدرة على مواكبة التغيير ات للحفاظ على التميز في الأداء التنظيمي. ويمكن تعريفها أيضا بقدرة المؤسسة في الاستجابة السريعة للمتغيرات المفاجئة في مجال عملها والتي تكسبها المرونة لتعديل وتغيير أهدافها وقرارتها وذلك بامتلاك مسئوليها الالتزام وتحمل المسئولية والحساسية الاستراتيجية (عنتر محمد أحمد عبد

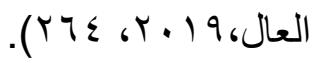


تأهيل مديني مدارس التربية الخاصة بدحافظة البحر الأحمر في ضوء محددات الرشاقة الإستراتيجية

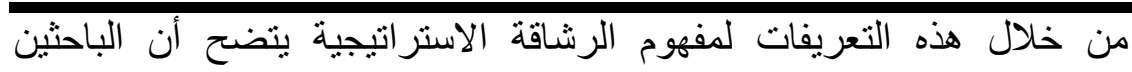

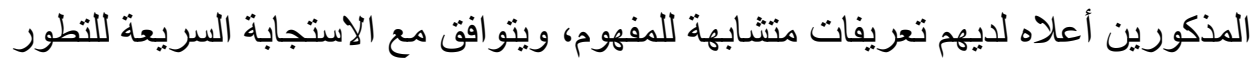
في البيئة المتغيرة والمرونة في التعامل مع المتغيرات المتغيرة.

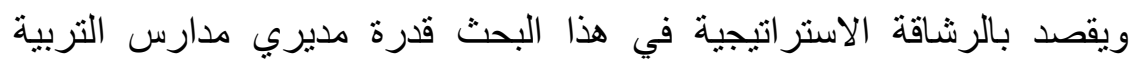
الخاصة علي دعم وقيادة التغيير الدفاجئ والاستفادة من الفرص الدتاحة في البيئة المدرسية الداخلية و الخارجية المتغيرة.

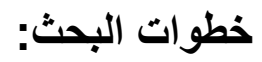

لكي ينحقق الهدف الرئيسي من البحث الحالي فأنها تسير وفقا الخطوات التالية:



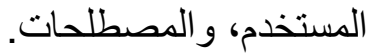
الخطوة الثانية: تحليل الإطار الفكري لمتغير الرشاقة الاستراتيجية في الأدبيات التربوية

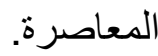

الخطوة الثالثة: التعرف على طبيعة دور مديري مدارس التربية الخاصة نظريا الخطوة الرابعة: الكثف عن واقع توافر محددات الرشاقة الاستراتيجية لاي مديري مدارس التربية الخاصة بمحافظة البحر الأحمر من وجهة نظر المعلمين والعاملين. الخطوة الخامسة: الكثف عن مبررات ودو اعي تأهيل مديري مدارس التربية الخاصة. الخطوة السادة: تقديم تصور مقترح لتأهيل مديري مدارس التربية الخاصة بمحافظة البحر الأحمر في ضوء محددات الرشاقة الاستراتيجية.

ثثانيا: الإطار الفكري للرشاقة الاستراتيجية في الأدبيات الإدارية المعاصرة لتناول الإطار الفكري للرشاقة الاستراتيجية سيقوم الباحث بعرض عدد من النقاط الهامة

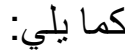
أ- مفهوم الرشاقة الاستر اتيجية.

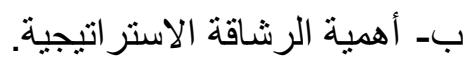




\section{د. رجب أحمد عطا محمد}

ج- محددات الرشاقة الاستراتيجية. د- دو اعي الرشاقة الاستر اتيجية. هـ - متطلبات تحقيق الرشاقة الاستر اتيجية. ويتتاول الباحث في الصفحات التالية تلك النقاط كما يلي: أ- مفهوم الرشاقة الاستراتيجية: تعتبر الرشاقة الاستراتيجية من المفاهيم الحديثة في علم الإدارة، وهي مفتاح النجاح في بيئة الأعمال غير المستقرة، وهي القدرة على دعم وقيادة التغيير المفاجئ من أجل الاستفادة من الفرص في بيئة متغيرة وتشكل الرشاقة الاستر اتيجية السمة المميزة للمنظمات المعاصرة لتأثيرها في تفسير كيفية أداء المنظمات لأعمالها بسرعة ودقة تمكنها من التفوق علي

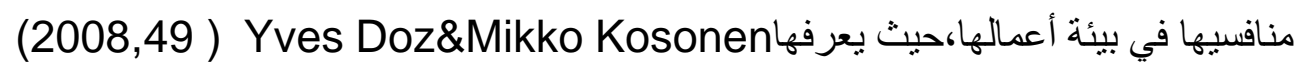
بالقدرة على تعديل الاتجاه الاستراتيجي وتكييفه باستمرار في الأعمال الأساسية ، كدالة للطموحات الاستر اتيجية والظروف المتغيرة، وخلق ليس فقط منتجات وخدمات جديدة ، لئل

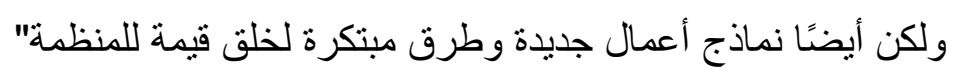

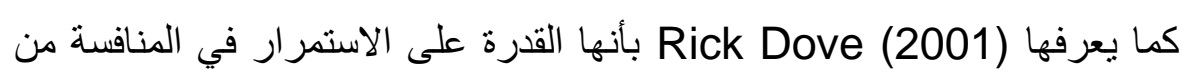
خلال الإدارة الفعالة للمعرفة والتركيز على السرعة في الاستجابة للاضطر ابات، وتوضيح أن مجالات السرعة هي: وقت تسويق منتجات جديدة، ووقت معالجة طلب أو الوال

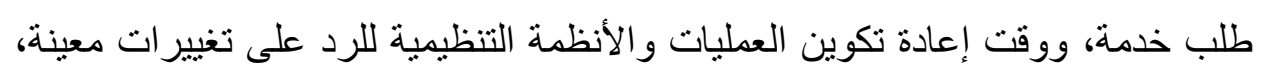
وما إلى ذلك.

Arbussa, و وقام كل من (2010,372 و و

بتحليل الرشاقة الاستراتيجية إلى ثلاث Bikfalvi \& Marquès $(2017,280)$ قدرات فوقية: الحساسية الاستراتيجية ووحدة القيادة وسيولة الموارد، والتي تسمح

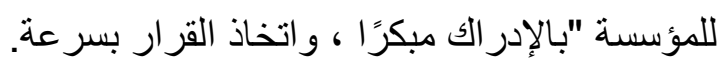


تأهيل مديريي مدارس التربية الخاصة بحافظة البحر الأحمر في ضوء محدات الرشاقة الإستراتيجية

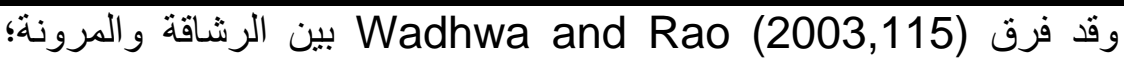

حيث تعني الرشاقة استجابة مبتكرة للتغييرات الكبيرة غير المتوقعة التي تتطلب التحكم في مجمو عة من الأنظمة وعلى جانب آخر ، فإن المرونة هي ببساطة الاستجابة للتغيرات الصغيرة والمتوسطة والمتوقعة التي تحتاج إلى التركيز على نظام واحد.

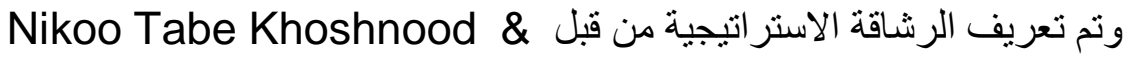

Sina Nematizade $(2017,220)$ المعرفة. كما أنهم يفسرون الرشاقة الاستراتيجية على أنها قدرة المنظمة على اكثثاف التغييرات من خلال الفرص والتهديدات الموجودة في بيئة الأعمال، وتقديم استجابة سريعة من خلال إعادة تجميع الموارد و العمليات والاستراتيجيات.

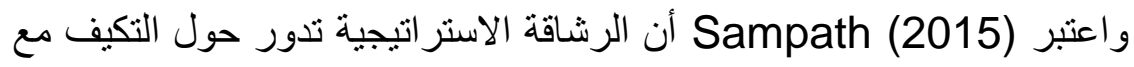
التغييرات في سياق الأعمال، و اكتثاف الفرص و التهديدات والمخاطر ، وإطلاق مبادرات

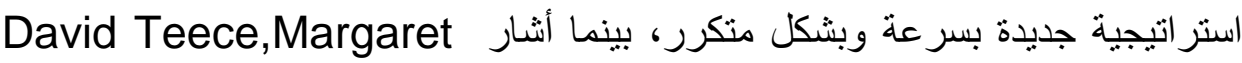
Peteraf and Sohvi Leih $(2016,14)$

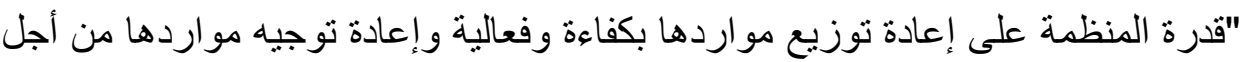
خلق القيمة وحماية (و التقاط) الأنثطة ذات العائد المرتفع كما تتطلب الظروف الداردانية

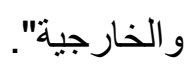

ومن ثم فالرشاقة الاستراتيجية من التعاريف السابقة تعني تلك الإجراءات

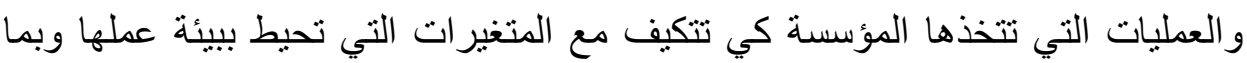
يمكنها من تتكيل استر اتيجيتها لتحقيق النجاح الاستر اتيجي. ب - مأهمية الرشاقة الاستراتيجية: تزداد أهمية الرشاقة الاستراتيجية باعتبارها أحد أهم الأنظمة التي تساهم في الأنياهي

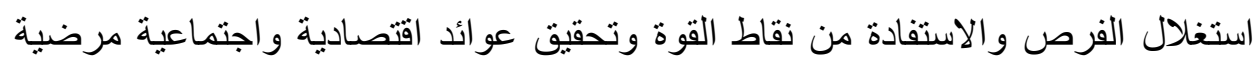

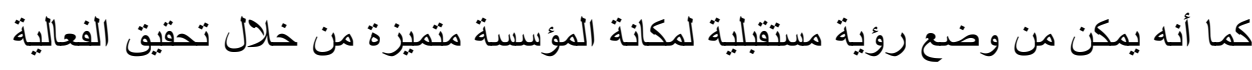


د. رجب أحمد عطا محمد

في استغلال مواردها المادية والبشرية ومواجهة التهديدات بغرض تحقيق الأهداف الاستر اتيجية.

حيث يثير Yves Doz\&Mikko Kosonen (2008,9) إلى أن الرشاقة

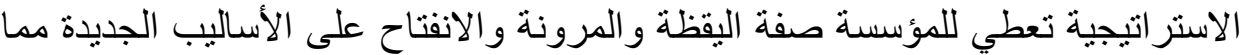

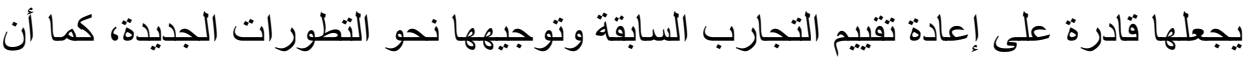
الرشاقة الاستر اتيجية تساعد المؤسسة على تعديل أو إعادة تثكيل استراتيجيتها بشكل ديناميكي في بيئة الأعمال المتغيرة.

وتعتبر الرشاقة الاستراتيجية طوق النجاة للمؤسسات في بيئة الأعمال

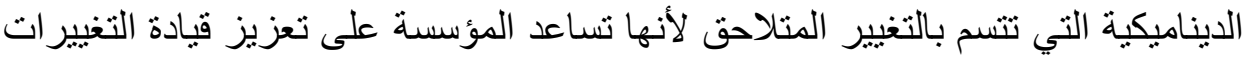
الغير متوقعة، واستغلال الفرص الممكنة في سوق مضطرب فهي تثجع على التفكير

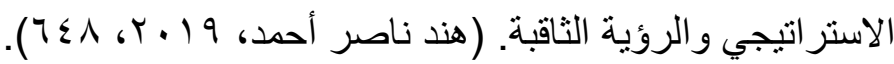

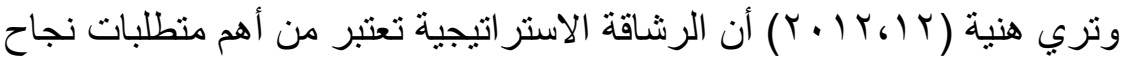

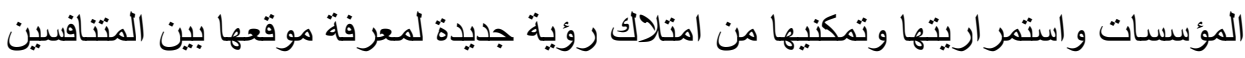

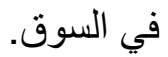

ولقد توصلت دراسة الرشاقة تعزز الفعالية النتظيمية فمن خلالها بمكن إدارة الاضطرابات البيئية الداخلية

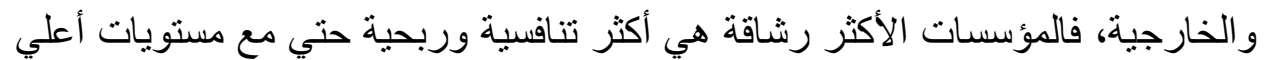
الاضطر اب لأنها تساعد المؤسسة علي البدء في إجر اءات تنافسية مرنة وفعالة ومتجددة للتفاعل بشكل متميز مع التغيرات السريعة والدفاجئة لتحقيق واقع منطور جديد. إن الرشاقة الاستراتيجية تمنح المنظمة إطار عمل مرن بمكنها من النجاح و التفوق من خلال تمتع فرق العمل بصلاحيات واسعة وممارسات اتخاذ القرارات بدرجة التحنة عالية على إدارة وضبط التغير المستمر فهي تعد المنظمة لقبول التغيير من خلال 
تأهيل مديزي مدارس التربية الخاصة بمحافظة البحر الأحمر في ضوء محددات الرشاقة الإستراتيجية

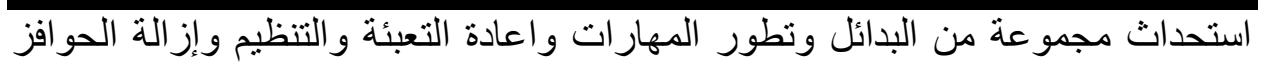

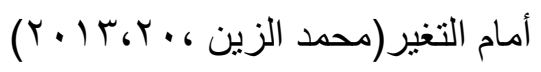

و أكد كل من Maarit Santala (2009) ، Divesh Ojha (2008) علي أن الرشاقة الاستراتيجية تعكس قدرة المنظمة على إدارة التغيير المستمر والتحكم فيه ، مع إعداد المنظمة لقبول التغيير من خلال توليد مجموعة من البدائل، وتطوير التئير الههارات، وإعادة التنظيم و إزالة الحواجز التي تحول دون التغيير. ويتيح التغيير المستمر الفرصة لمنافسة أكبر في بيئة ديناميكية، ويمكن تكييف هذه التغييرات من قبل المنظمات التي لديها الرشاقة الاستراتيجية من خلال استجابتها السريعة لهذه التغييرات،

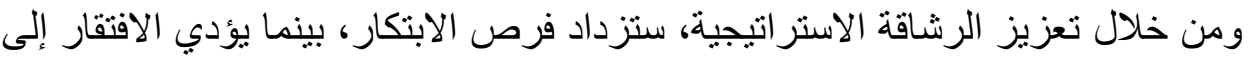
محددات الرشاقة الاستراتيجية إلى ضياع الفرص. لا تعني الرشاقة الاستراتيجية

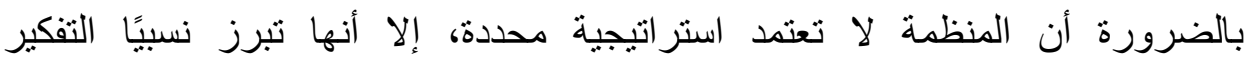


مشتركة لتحسين الاستر اتيجية وتتفيذها بدلاً من الفصل بينهما. واليوم، تو اجه المنظمات عدم اليقين وعدم الاستقرار على المستوى الاقتصادي و الاجتماعي و السياسي والتكنولوجي وحتى على المستوى الفردي. كما تتخير باستمرار

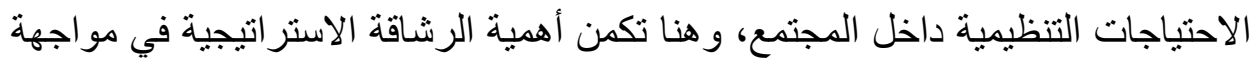

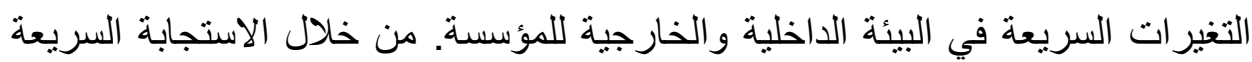

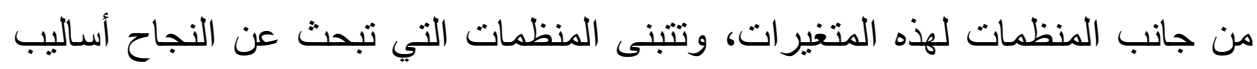

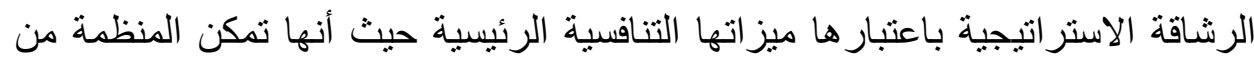

$$
\text { تحقيق أهدافها بدقة وسر عة. }
$$

\section{ج- محددات الرشاقة الاستراتيجية}

يتتاول الباحث في هذا المحور مجموعة من المحددات أو القدرات الأساسية التي لئي

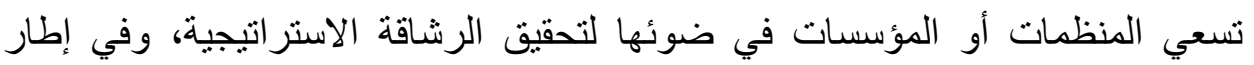


د. رجب أحمد عطا محمد

اهتمام المنظمات بالإجابة عن تساؤل مفاده: كيف يمكن للمنظمة أن تصبح أكثر رشاقة،

ويمكن قياس الرشاقة الاستر اتيجية بمجمو عة من المحددات. ومن أهم هذه المحددات . لقد اتفقت معظم الدراسات علي أن محددات الرشاقة الاستراتيجية التي تحتاجها المؤسسة من أجل الحفاظ علي فعاليتها واستمر ارها تتمثل في: Yves Doz\&Mikko) Kosonen, 2008, Donald Sull,2009,80, Divesh Ojha,2008, Radwan, Tariq,2014,227, Maarit Santala,2009, Long,2000,25, Ade Oyedijo.2012,31, Nikoo Tabe Khoshnood \& Sina Nematizade,2017,221,Samer Abu-Radi,2013,45, Francesco

Debellis, et al,2020,4 ) - - الحساسية الاستر اتيجية: الانفتاح و الاستبصار وتعني قدرًا كبيرًا من المعلومات من خلال الحفاظ على العلاقات مع مجمو عة متنوعة من الأفر اد والمنظمات، وتثشير إلي تحديد واستغلال الفرص المستمرة بشكل أسرع من المنافسين، وتتكون الحساسية الاستراتيجية من الركائز الثثلاث الرئيسية، وهي أولاً: عليات الاستراتيجية المفتوحة وتشمل عنصرين رئيسيين: التعاون الاستر اتيجي مع العديد من المساهمين، و الخبرات العلمية بين أعضاء المنظمة، ثانيا التأكيد على اليقظة الاستر اتيجية: كما تشمل ثلاثة عناصر رئيسية وهي مرونة الرؤية، والأهداف المتناقضة، والانفتاح على الرؤية المستقبلية، ثالثاً: حوار داخلي عالي الجودة: ويتكون أيضًا من عنصرين، واقع الإثراء المفاهيمي والتنوع المعرفي. ومن خلال هذه الركائز، يمكن للمؤسسة الوصول إلى الحساسية الاستراتيجية وبالتالي بناء الرشاقة الاستراتيجية و الوصول إلى تحقيق أهداف المنظمة في أسرع وقت ممكن وبأقل التكاليف الممكنة. - القدرات الأساسية: تعنبر معرفة الثخص بقدراته العامل الأهم في نجاحه في تحقيق أهدافه وتطلعاته ، كما أن و عي المنظمة بقدر اتها الأساسية والمهارات التي تتميز بها هي عنصر مهم وحيوي في وضع قابل للتحقيق الأهداف، ويمنحها قدرة عالية على 
تأهيل مدييي مدارس التربية الخاصة بحافظة البحر الأحمر في ضوء محدات الرشاقة الإستراتيجية

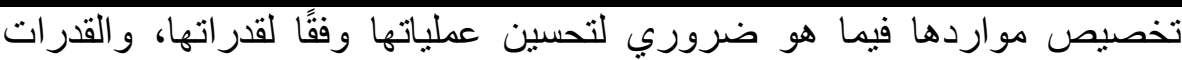
الأساسية هي مهارات المنظمات والميزات المعرفية الموجهة لتحقيق رضا المستفيدين مقارنة بالمنافسين، وتعبيراً عن وعي الدنظمة بالقدرات المطلوبة لكيفية رفع كفاءة الأداء والاستفادة من الفرص حيث أن المنظمة التي لا تدرك قدراتها الأساسية ستعمل بشكل ضعيف، ومن الضروري هنا إيجاد وتحديد المهارات والمعرفة التي تتوافق مع قدراتها الأساسية، وقد تتخذ القدرات الأساسية أثنكالًا مختلفة، مثل المهارات الفنية والنظرية والنقدية والعلمية التي يمكن استخدامها في المنظمة، وأن القدرات الأساسية تزود المنظمة بمزيج ضروري من السرعة النية

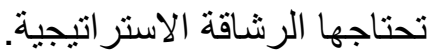

- وضوح الرؤية: إن وجود رؤية واضحة للمؤسسة هو الخطوة الأولى في التخطيط

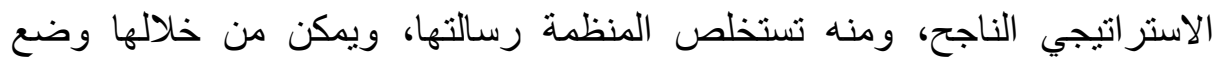
أهداف واضحة تسعى المنظمة إلى تحقيقها وتجيب على أهمها سؤال لأي منظمة وهو

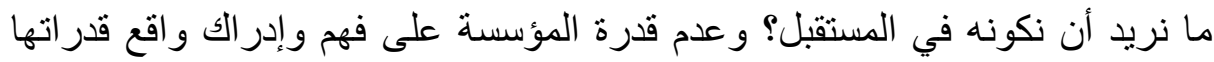

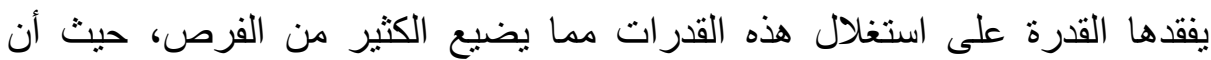

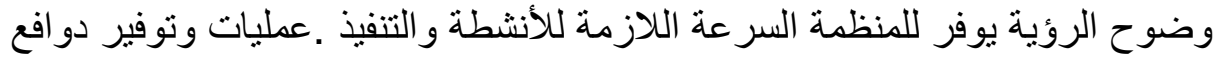
لجميع الأطر اف داخل سلسلة القيمة الني تمكنهم من استغلال الفرص المناسبة. - - المسؤولية المشتركة: نعني اتخاذ القرارات في المنظمة من قبل الفريق بأكمله بطريقة تقود جميع أعضاء الفريق إلى النجاح الجماعي والثراكة في المسؤولية و الالتزام الجماعي من قبل جميع الأطراف يمكن أن تخلق قيمة المنظمة التي تعثد التئد

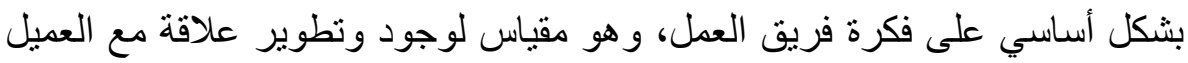
من أجل المساهمة في خلق القيمة، لأهمية مشاركة الأفراد في اتخاذ القرار و الإدارة بالمشاركة والقيادة الجماعية وحل المشكلات بشكل جماعي، وأهمية مشاركة الأفراد

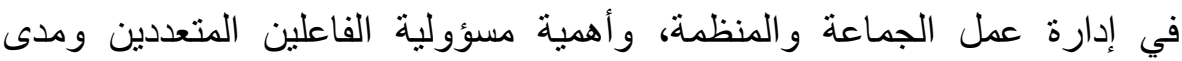


د. رجب أحمد عطا محمد

مساهمتهم في تحقيق النتائج والمخرجات بشكل جماعي، حيث من الضروري الاعتماد على تكوين النتائج بشكل تر اكمي وجماعي، وتمثل المسؤولية المثتركة مقياسًا للقيمة المتر اكمة المنظمة من خلال بناء علاقات مع شركاء سلسلة القيمة، حيث أن علاقتها مع المستقيدين هي أهم مساهمة في خلق القيمة. - - الاستجابة السريعة: وهي تعكس الدرجة التي يمكن للمؤسسة أن تتخذ إجراءات فورية عندها وعند نقطة معينة مثل فرصة لتقديم منتج جديد ووظيفة هذا البعد هي جعل المنظمة في تجدد مستمر، و هذا يقع على عاتق المدير من خلال توجيه الأفراد لأداء أفضل من الواجبات والمهام الموكلة إليهم ولكن هذا يقود المنظمة لتحقيق الكفاءة والفعالية وسر عة الاستجابة للمتغيرات المحيطة، وأن سر عة الاستجابة هي مصدر جديد للميزة التنافسية مثل العديد من الشركات، وهذا يتطلب أن توصف المنظمة بأنها سريعة الحركة، وكذلك تفويض اتخاذ القرار إلى أدنى المستويات في المنظمة، وأن يتم العمل من قبل فرق من مختلف المهار ات لكل من سرعة الاستجابة و المسؤولية المشتركة، يمكننا أن نستنتج أن قدرة المنظمة على التكيف بسرعة مع التغيرات في البيئة الخارجية فيها تمكن المنظمة من توفير الوصول إلى المعلومات للعاملين أو الاحتفاظ بها وإثراكهم بشكل كبير في تخطيط وتنفيذ الإجراءات و المشاركة في اتخاذ القرار في المنظمة.

- اختيار الأهداف الاستراتيجية: أب منظمة ، بغض النظر عن حجمها ، صغيرة أو كبيرة أو مهما كان نشاطها الإنتاجي أو الخدمي يختلف، لديها هدف أو مجمو عة من الأهداف، و عملية اختيار الأهداف الاستر اتيجية المتعلقة برسالة المنظمة مسئولية السلطات العليا، وغالبًا ما تكون هذه الأهداف هي النتائج التي تسعى المنظمة لتحقيقها ومن أجلها تؤهل أو تعزز أو تطور قدراتها لتتماثى مع الفرص الحالية أو الناثئة، فهي هدف ومسعى لكل منظمة ثريد تحقيق النجاح، واختيار الأهداف الاستر اتيجية هي النقاط النهائية أو النتائج الأساسية التي تسعى المنظمة إلى تحقيقها 


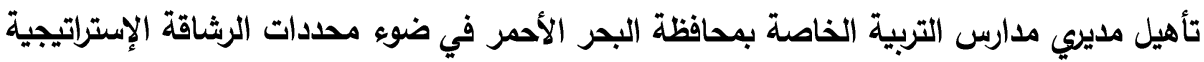

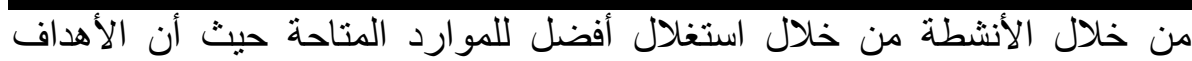

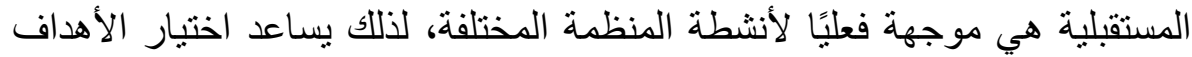

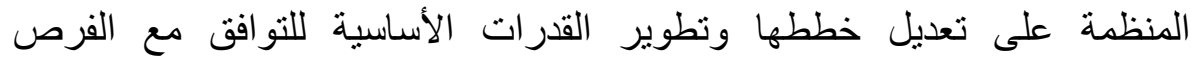

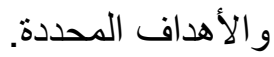

- - ماتخاذ الإجر اءات: يعكس مفهوم اتخاذ الإجراءات درجة التوجه نحو العمل الذبي

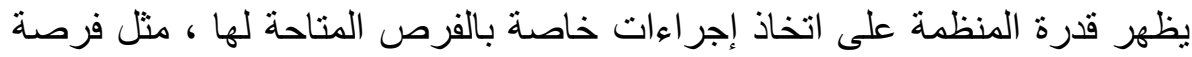

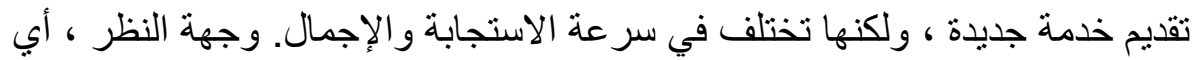
أن وظيفة هذا البعد هي وضع المنظمة في حركة مستمرة لأن هذا يقود المنظمة إلى الى تحقيق الكفاءة والفعالية ، ويرتبط هذا البعد بتو افر عناصر التتسيق بين جميع وحدات العمل المختلفة بشكل يضمن الاستجابة السريعة والتغطية الثشاملة لجميع مجالات العمل التي تضمن تنفيذ الأنثطة والدهام التي تحقق النتائج المرجوة و هنا لا بد من التهن وجود علامة على أهية تثجيع الحوار والنقاش بين جميع الجهات المسؤولة عن تتفيذ الاستراتيجيات، بالإضافة إلى تثجيع المبادرات وتبادل الأفكار المتعلقة بتنفيذ الهيذ

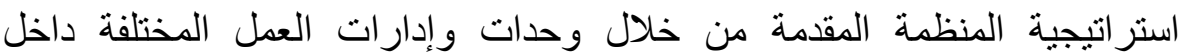
المنظمة ومن الضروري أن تمتلك المنظمة القدرة على تكييف استر اتيجيتها لتتاسب الظروف المتغيرة دون إغفال الغرض العام من وجودها. كما يوضح (2008) Yves Doz\&Mikko Kosonen. أن هناك ثلاث محددات للرشاقة الاستراتيجية تحتاجها المؤسسة من أجل النمو والتميز والاستمر ارية وهي: - - الحساسية الاستراتيجية (حدة الإدراك وكثافة الوعي والاتنتاه) تجمع بين البصيرة و التبصر المبكر والحاد بالاتجاهات الأولية والقوى المتقاربة التي تخلق المعنى في الوقت الحقيقي أثناء تطور ها، يتم تعزيز الحساسية الاستر اتيجية من خلال الجمع بين عملية استر اتيجية قوية ذات توجه خارجي وتثناركي داخلي، ومستوى عالٍ من الانتباه وحوار داخلي ثري ومكثف ومنفتح. كما تعني الحساسية الاستراتيجية الانفتاح على وسلى 
د. رجب أحمد عطا محمد

أكبر قدر ممكن من المعلومات والذكاء و الابتكار من خلال إنشاء علاقات مع مجموعة متنو عة من الأشخاص و المنظمات و المحافظة علي هذه العلاقات

- وحدة القيادة: تتضمن قدرة الفريق الأعلى على اتخاذ قرارات جريئة بسر عة، دون الانغماس في سياسات "الفوز والخسارة" على القمة .تسمح وحدة فريق القيادة بالوصول إلى القرارات بسرعة فائقة بمجرد فهم الموقف الاستراتيجي وفهم الخيار ات التي يتم فتحها أو إغلاقها فكريًا .تظل هذه القرارات ثابتة، فالالتز امات لا تتأخر بسبب انعدام الأمن الثخصي؛ ولا يخضع تتفيذها للأجندات الثخصية والخلافات الخاصة التي من شأنها أن تبطئ أو تعطل الجهد. حتى عندما تكون صادقة ، تظل الالتزامات جيدة مثل المصادر الموضوعة وراءها، تسهل وحدة القيادة عملية اتخاذ القرارات الجريئة بحيث لا يتحمل شخص واحد منفرد مسؤولية اتخاذ هذا القرار, بل يلتزم القريق كاملاً، و إذا كانت عملية صنع القرار ذات جودة عالية وكان الجميع يعمل بشكل جماعي, فإن وحدة الفريق تصبح عاملاً محفزاً يزيد من التماسك داخل الفريق.

- - سيولة المو ارد: تتضمن القدرة الداخلية على إعادة تكوين أنظمة الأعمال و إعادة توزيع الموارد بسرعة، بناءً على تخصبص الموارد ، وأساليب إدارة الأفراد ، وآليات وحو افز التعاون التي تجعل نماذج الأعمال وتحويل نظام النشاط أسرع و أسهل. وتعد سيولة الموارد أمراً أساسياً فبدونها تبقى الحساسية الاستراتيجية ووحدة القيادة بلا فائدة في تحقيق الرشاقة الاستر اتيجية و المطلوب لتحقيق ذلك هو مجموعة متنو عة من الوحدات المستقلة، وكادر من المديرين الذين بمكن نقلهم عبر الوحدات. - - التكنولوجيا: تعد القدرات التكنولوجية وتطبيقاتها المختلفة أهم الأدوات المساعدة في تحسين قدرة المنظمات علي امتلاك مقومات الرشاقة الاستر اتيجية بوصفها استجابة مناسبة للتغيير الذي تشهده المنظمات في إطار بيئة مضطربة شديدة التغيير، وتعتبر تقتية المعلومات العامل الأساسي في تحديد قدرة المنظمة علي اكتشاف التغيرات 
تأهيل مديني مدارس التربية الخاصة بحافظة البحر الأحمر في ضوء محددات الرشاقة الإستراتيجية

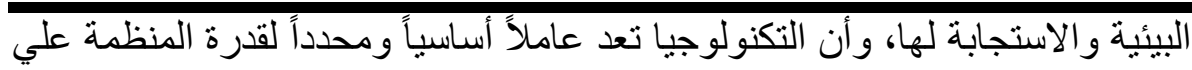
مواجهة التحديات والمخاطر البيئة واستغلال الفرص المتاحة، كما تعد مرونة تقنية المعلومات من الأمور الهامة عندما تمتلك المنظمة القدرة علي تحديد الكيفية والوقت الكتال

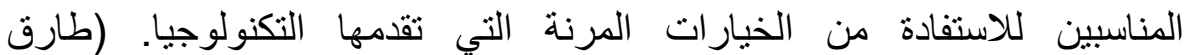

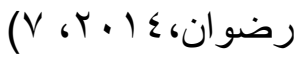

وستعتمد البحث الحالي علي المحددات التالية (الحساسية الاستراتيجية، وحدة الفريق،

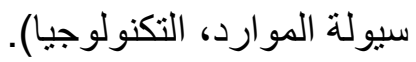
دـ - دواعي الرشاقة الاستراتيجية يشها المجتمع المدرسي وخاصة مدارس التربية الخاصة العديد من التغيرات و التطورات المتسارعة نتيجة ازدياد حدة العولمة والمنافسة واقتصاد المعرفة والانفتاح

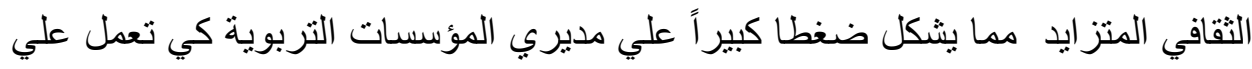

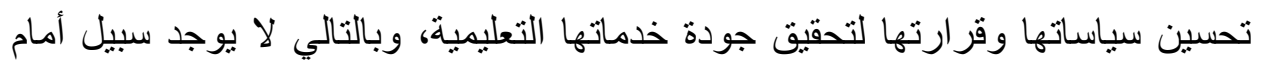
مديري المدارس الخاصة سوي التوجه إلي الررونة والدقة و الابداع في الفكر و التطبيق، و هناك عدد من الدواعي للاعتماد علي الرشاقة الاستر اتيجية وتحقيق محدداتها في إدارة

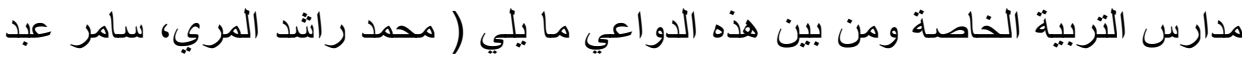

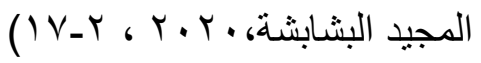

- - تزيد الرشاقة الاستراتيجية قدرة المنظمات علي تعزيز قدراتها التنافسية وتثجيع

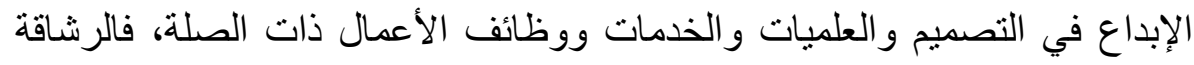

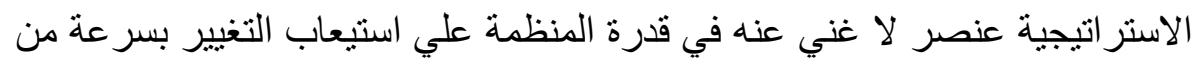
أجل السعي الطويل الأجل للنمو وتحقيق الميزة التنافسية . - - أدركت المنظمات الني تسعي إلي تحقيق النجاح أن الاستدامة والاستمر ارية و البقاء

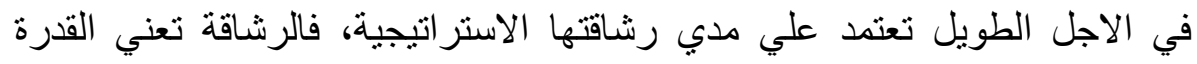




\section{د. رجب أحمد عطا محمد}

و البقاء والازدهار في بيئة تنافسية متغيرة باستمرار عن طريق التفاعل بسرعة مع الأسواق المتغيرة، وتقديم خدمات جديدة غير متوقعة.

- - الرشاقة هي أفضل طريقة للتنافس والبقاء في السوق، حيث تمكن المنظمة من سرعة الحركة والتكيف مع التغييرات غير المتوقعة في بيئة العمل، واستغلال الفرص المتاحة التي توفر ها التغيير ات في بيئة العمل. - - وجود تأثير إيجابي للرشاقة الاستر اتيجية بأبعادها( الحساسية الاستر اتيجية، ووحدة القيادة، وسيولة الموارد) في تحقيق التنفيذ الفعال للاستراتيجية وتحقيق الثقافة التحفيزية للمو اطنين ورضا العملاء وتحقيق نمو الأعمال.

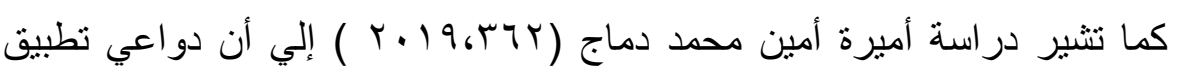
الرشاقة الاستر اتيجية في إدارة المدارس تتمثل في : - - الإدارة المدرسية الرشيقة تعمل علي حشد قدرات المدرسة وجهودها ومواردها و التنسيق بينها للوصول الى التجديد كهف استراتيجي، من خلال تدريب وصقل مهارات الموظفين وتنمية مواهبهم من أجل الابتكار والإبداع وتشجيعهم، واتاحة المعلومات وقو اعد البيانات لدعم استراتيجية التميز، و هذا سيؤدي بدوره إلى انتاج افكار جديدة تستفيد منها ادارة المدرسة في التجديد و التطوير . - - تعمل الرشاقة الاستراتيجية على تحليل البيئة المدرسية الداخلية والخارجية وتحديد موارد القوة و الضعف و الفرص والتهديدات وتحديد البدائل والخيارات الاستر اتيجية والتركيز على جودة الموارد كهدف استراتيجي تنافسي للمدرسة تستطيع الوصول من خلاله إلى التميز. ولقد أوضحت دراسة نور محمد سالم الزبن (r ا ب) أن العديد من المنظمات تو اجه تغيير ات سريعة وطارئة، وأن بعض المنظمات تمتاز بالكفاءة العالية في مرحلة معينة من دورة حياتها للمحافظة علي هذا التقدم والتميز ينبغي عليها اعتماد الرشاقة الاستر اتيجية كوسيلة فعالة لاستمرار هذا التفوق. 
تأهيل مديزي مدارس التربية الخاصة بححافظة البحر الأحمر في ضوء محدات الرشاقة الإستراتيجية وقد أثنار (2008,133

التغيير معقدة ومعدل سرعته كبير جدا، ولذلك المنظمة تعتمد علي الرشاقة الاستراتيجية كمدل لتحقيق التحرك بمرونة كبيرة والتكيف و التوافق السريع لمقابلة التغيير في محيط المنظمة لضمان استمر ار وبقاء وحيوية المنظمة وتقديم خدماتها للمجتمع. ومن ثم فإن تنني فكر الرشاقة الاستراتيجية والإعداد لها وتطبيقها يضمن

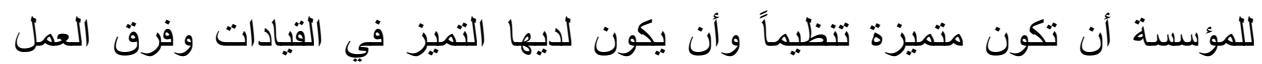
والعطليات وجودة الأنثطة والأعمال والأداء المالي. هـ منطلبات تحقيق الرشاقة الاستر اتيجية. لرشاقة الاستراتيجية ليست سمة يمكن لأي منظمة امتلاكها بسهولة، ولكن يجب الاسب استكمالها بمجموعة من الممارسات والأنشطة المنهجية الموصوفة كنطلبات للمنظمة للحفاظ على مزاياها التنافسية بالإضافة إلى الاستجابة السريعة التغييرات وأحداث الطو ارئ في بيئة مضطربة ومتسار عة في المنظمة، ومن أهم متطلبات تحقيق الرشاقة الاستر اتيجية ما يلي( Muhammad Hamdan,et al,2020,82-83) : ـ الحاجة إلى علاقات تعاونية بين زملاء العمل. - حاجة المنظمة لقاعدة بيانات تستطيع من خلالها تتويع مصادر نظم المعلومات. ـ ـ تكامل الأدوار والأعمال عبر جميع مسنويات المنظمة. ـ - المنظمة لديها قادة أقو ياء.

ـ توفر العو امل الاجتماعية الضرورية المتعلقة بالثقة وتوازن القوى بين الثركاء ، كما فادياء تلعب الثقة دورًا في تمكين المنظمات من مشاركة المعرفة وزيادة رغبتها في الاختيار و الحصول على المزيد من المعلومات و البيانات التي تساهم في صناعة القرارات ـ الحاجة إلى مناخ تنظيمي يثجع التميز والإبداع وخفة الحركة. - مثقافة تنظيمية داعمة ومرنة. ـ امتلاك هيكل تنظيمي مرن وتحسين العطليات وتطوير ها أكثر من المنوقع. 


\section{د. دجب أحمد عطا محمد}

- قدرة المنظمة على تحديد الأعمال والقرات والعمليات الأساسية التي تمكنها من مو اجهة المخاطر و التهديدات والتحديات الحالية والمستقبلية. وتحتاج أي منظمة لتحقيق الرشاقة مجموعة من المتطلبات من أهمها

:(Arokodare, \& Asikhia,2020,10-11)

- - البصيرة الاستر اتيجية: تشير إلي التركيز على الحاضر من خلال استخلاص المعرفة دن المواقف الاستراتيجية المعقدة عند ظهورها وتحليلها حتى تستفيد المنظمة من المو اقف عند ظهور ها. في سياق المنظمة ، يشمل البصيرة الاستر اتيجية كل من الرؤية الخارجية ، أو الاستشعار الخارجي والرؤية الداخلية ، أو الوعي الداخلي. بسلط الوعي الداخلي من خلال الفحص والتجريب الضوء على قوة المؤسسة وضعفها في ضوء البيئة، وقد يؤدي ذللك إلى تحدي افتر اضات العمل الأساسية للمنظمة، ويساعد على تحديدها وصقلها من ناحية أخرى، ويتيح الاستشعار الخارجي للمديرين التنفيذيين رؤية مؤسستهم من وجهات نظر مختلفة

عندما يبتعدون عن جمودهم الفكري والبدء في نمذجة المنظمة و علاقتها ببيئتها. - الاستجابة الاستر اتيجية الداخلية: هي قدرة المنظمة، التي تعمل بالتعاون مع عملائها وشركائها التجاربين، على إعادة تكوين مواردها و عملياتها بسر عة وبسلاسة للتفاعل أو الاستباقية بما يتماشى مع التغييرات أو التطور ات في بيئة الأعمال. - - الاستجابة الاستر اتيجية الخارجية: هي القدرة على التنبؤ بحدوث وتطورات السوق قبل المنافسين إنها تشير إلي الانفتاح على أكبر قدر من المعلومات ،الذكاء و الابتكار ات قدر الإمكان من خلال إنشاء والحفاظ على العلاقات مع مجمو عة منتوعة من الأشخاص و المنظمات المختلفة، ومن ثم، تحتاج المنظمات إلى أن تكون موجهة نحو السوق لكي تدرك الحاجة إلى التغيير. وينظر إلي توجيه الاستجابة الخارجية، باعتبار ها قدرة المنظمة على إعادة التصرف أو اتخاذ إجراءات مع بيئة الأعمال. 
تأهيل مديني مدارس التربية الخاصة بمحافظة البحر الأحمر في ضوء محددات الرشاقة الإستراتيجية - قدرة الموارد البشرية: تعني قدرة الأفراد ومرونتهم في القيام بأدوار حاسمة في منظمة رشيقة تواجه تغييرًا دائًًا في الظروف. قدرة الموارد البشرية هي مقياس لقدرة القوى العاملة وكفاءتها لأداء واجباتهم بفعالية وكفاءة. وهي عبارة عن مجموعة من الممارسات والسياسات اللازمة لتنفيذ الأنشطة المختلفة. من خلالهم ، وتقوم الإدارة بوظيفتها بأفضل ما لديها من قدرات. يمكن أيضًا وصف قدرة الموارد البشرية ، على أنها نشاط إداري متعلق بتحديد احتياجات المشروع من حيث المرونة الاستراتيجية لتحقيق أداء تنظيمي متفوق من خلال قوة عاملة لديها القدرة علي الاستشر اف الاستر اتيجي و الاستجابة لهذه الاحتياجات من خلال توفير القوى العاملة المناسبة ضمن الأعداد والمؤهلات التي تتوافق مع احتياجات المشروع، واستخدام هذه الموارد بطريقة فعالة لتحقيق الإنتاجية. - قدرة تكنولوجيا المعلومات: تعتبر تكنولوجيا المعلومات أحد متطلبات تحقيق الرشاقة الاستراتيجية، وتوصف بقدة المنظمة على استخدام البنية التحتية للمعلومات ومواردها بنجاح لاشتقاق القيمة من أجل تحسين أدائها. وأي منظمة لديها البنية التحتية للمعلومات والموارد اللازمة لوظائفها الأساسية ستكون قادرة على تنفيذ وظائفها بفعالية في حين أن امتلاك مثل هذه القدر ات مهم للمنظمة لاستخدام مواردها المعلوماتية وتعزيز إدارة المعلومات في عمل تتافسي. كما تتطلب الرشاقة الاستراتيجية قرات وموارد محددة للشركات. يجب تتو افر الرشاقة في كل عنصر من عناصر الأعمال بما في ذلك الهيكل التنظيمي والثقافة والتكنولوجيا والقيادة والإدارة ويجب أن تعزز إدارة المنظمة ثقافة الرشاقة، مع التأكيد على أهميتها للموظفين في كل مستوى من مستويات المنظمة، وفي الو اقع ، يتم استخدام الهيكل التنظيمي وأنظمة المعلومات و العقليات الخاصة بأولئك الأفراد داخل المنظمة معًا لتمكين المنظمات من التصرف بشكل رشيق، ويعتبر الاتصال أهم قدرة في التصرف السريع حيث يمكّن الاتصال المنظمات من دمج الموظفين في مستويات هرمية مختلفة،

$$
\begin{aligned}
& \text { العدد الخامس والاربعون (الجزء الاول) ب ب r r } \\
& \text { مجلة كلية التربية- جامعة عين شمس }
\end{aligned}
$$


د. رجب أحمد عطا محمد

بالإضافة إلى دمج الهيكل التنظيمي والثقافة وللهيكل التنظيمي تأثير كبير على القدرة التنظيمية على التصرف السريع حيث يسمح الهيكل الأفقي للمنظمات بتجنب العمليات الرسمية الصارمة التي تبطئ سر عة استجابتها للتغيرات البيئية. لضمان خفة الحركة في

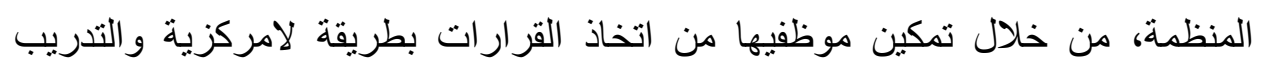
المستمر والتطوير المؤدي إلى بناء القدرات بمهار ات متعددة ومرونة في إنجاز المهام كما أن الاستثمار في الموظفين وغرس قدراتهم في العمل والانضباط الموجهين ذاتيًا

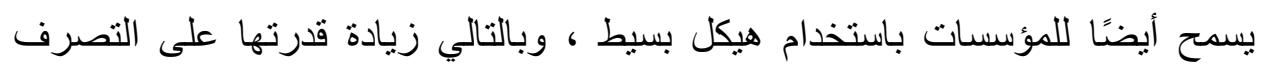
بسر عة. و هذا يؤكد كذلك على أهمية الموظفين كمورد في تحقيق الرشاقة الاستر اتيجية.

(Bella Butler,Kayla Surace,2015,8)

وتعليقا على ما ورد برى الباحث أن من أهم منطلبات الرشاقة الاستراتيجية

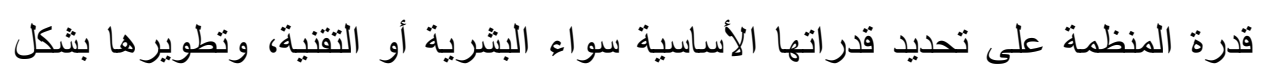

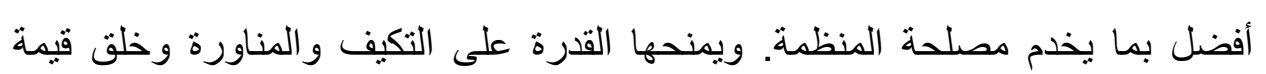
مميزة معها بهيكل تنظيمي وبنية تنظيمية داعمة ومرنة وتثاركية في اتخاذ القرار وات. ثالثا: طبيعة دور مديري مدارس التربية الخاصة تعد مدارس التربية الخاصة من أهم المؤسسات التي يمكن أن تسهم في إثراء

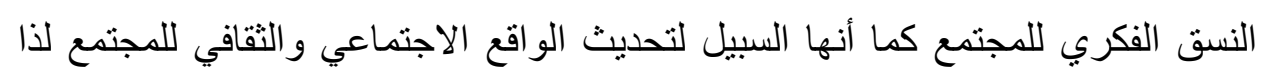
نالت اهتماماً كبيراً من مختلف دول العالم في العصر الحديث، وتهدف مدارس التربية الخاصة في مصر إلي تربية وتعليم وتأهيل ذوي الاحتياجات الخاصة بفئاتهم المختلفة، كما تهدف إلي تدرييهم علي اكتساب المهارات المناسبة حسب إمكاناتهم وقدراتهم وفق خطط مدروسة وبرامج خاصة بغرض الوصول إلي أفضل مستوي و إعدادهم للحياة

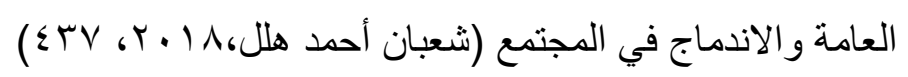
وتعد مدارس التربية الخاصة متميزة عن غيرها من المدارس لما تحويه من

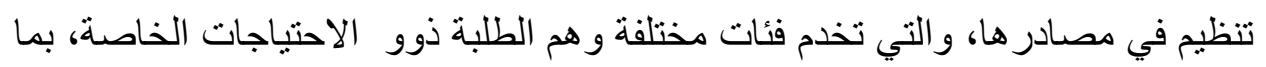


تأهيل مديريي مدارس التربية الخاصة بحافظة البحر الأحمر في ضوء محددات الرشاقة الإستراتيجية

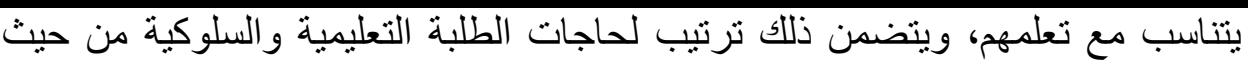
مر اعاة حجم الصف العادي، وتوفير مساحات كافية لتمكين المعلم من تدريس الطلبة بشكل فردي أو مجموعات صغيرة، وتوفير مساحات لتخزين المواد التعليمية والمعلومات بالقرب من الطلبة، وتنظيم المبني المدرسي من جهة أخري، وتوفير بيئة

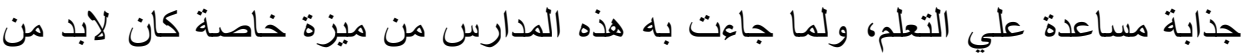
وجود إدارة ناجحة مسئولة عن إعداد برامج الخدمة التربوية والتي تختلف في مضامينها عن برامج التربية الاعتيادية وتتفرد عنها ببعض الخصوصيات من حيث التخطيط لها وتهيئة المناهج التعليمية الخاصة و التي تساعد غير العاديين من الأفر اد في تحقيق التوافق

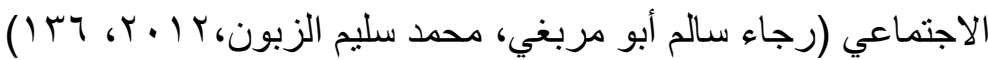
وتقوم فلسفة التربية الخاصة علي العديد من الأمور منها: (DiPaola, ونانيان تكامل المعلومات حيث يعتمد تحقيق أهداف التربية

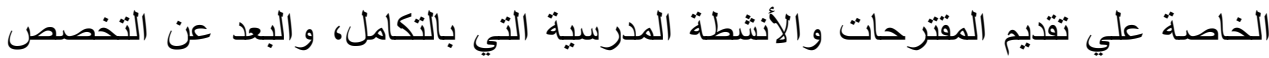
الضيق، ولضمان نجاح مدير المدرسة في تتفيذها بالدرجة المنشودة يتطلب إعداد مدير تربية خاصة يتفهم أبعاد التربية الخاصة، ويستطيع أداء أدواره بكفاءة، وإعداد مدير يتفهر

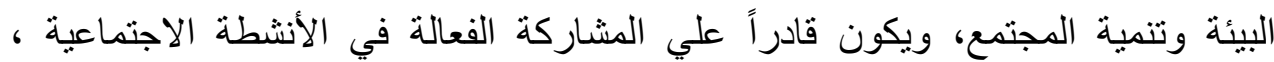
و إعداد مدير يتفهم جيداً هذخلات نظام تعليم ذوي الاحتياجات الخاصة ومخرجاتهاته، ومتفهما لفلسفة هذا التعليم وأهدافهن وأبعاده الاجتماعية من أجل تهيئته لما يقوم به من أدوار. حيث تهدف التربية الخاصة إلي تربية وتعليم وتأهيل الأطفال ذوي الاحتياجات التربوية الخاصة بفئاتهم المختلفة ، كما تهدف إلي تدرييهم علي اكتساب المهارات المناسبة حسب إمكانياتهم وقدر اتهم، ويمكن إجمال الأهداف الرئيسية للتربية الخاصة في

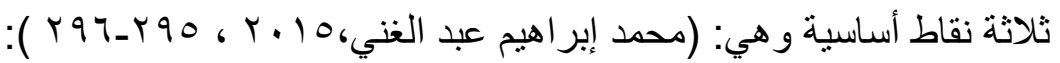

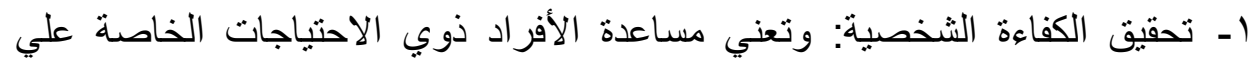

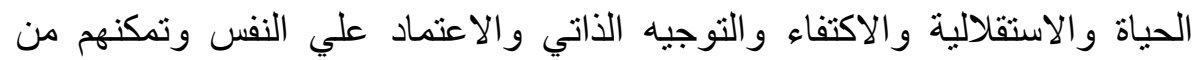




\section{د. دجب أحمد عطا محمد}

تصريف أمور هم الشخصية والعناية الذاتية بدرجة تتناسب وظروفهم الخاصة بحيث لا يكون عالة علي الآخرين، وذلك بتنمية إمكاناتهم الثخصية واستعداداتهم العقلية

$$
\text { و الجسمية و الوجدانية و الاجتماعية. }
$$

ץ- تحقيق الكفاءة الاجتماعية: وتعني غرس وتنمية الخصائص والأنماط السلوكية اللازمة للتفاعل وبناء العلاقات الاجتماعية المثمرة مع الآخرين، وتحقيق التوافق الاجتماعي لذوي الاحتياجات الخاصة ، و إكسابهم المهار ات التي تمكنهم من الحركة النشطة في البيئة المحيطة والاختلاط والاندماج في المجتمع والتي تمنحهم الثعور بالاحترام و التقدير الاجتماعي وإثباع احتياجاتهم النفسية إلي الأمن والحب و الثقة بالنفس. ب- تحقيق الكفاءة المهنية: وتعني إكساب ذوي الاحتياجات الخاصة بعض المهارات اليدوية والخبرات الفنية المناسبة لطبيعة إمكاناتهم واستعداداتهم والتي تمكنهم بعد ذللك من ممارسة بعض الحرف المهنية. كما يفضل أن تتضمن أهداف التربية الخاصة أهدافاً اجتماعية ونفسية وأكاديمية

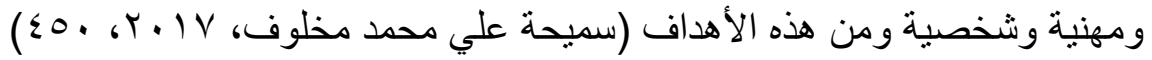
- ـتمية وتدريب الحواس المتبقية لاي ذوي الاحتياجات الخاصة للاستفادة منها في اكتساب الخبر ات المتنو عة و المعارف المختلفة. - توفير الاستقرار والرعاية الصحية والنفسية والاجتماعية التي تساعد ذوي الاحتياجات الخاصة علي التكيف مع المجتمع. - - تعديل الاتجاهات التربوبة الخاطئة لأسر هؤلاء الأطفال عن طريق التوعية و التوجيه و إيجاد مناخ ملائم للتعاون الدائم بين المدرسة والأسرة. - - إعداد الخطط الفردية التي تتلاءم مع إمكانات وقدر ات كل طفل. ـ - الاستفادة من البحث العلمي في تطوير البرامج والوسائل والأساليب المستخدمة في مجال التربية الخاصة. 


\section{تأهيل مديزي مدارس التربية الخاصة بمحافظة البحر الأحمر في ضوء محددات الرشاقة الإستراتيجية}

- الكثف عن مواهب واستعدادات وقدرات كل طفل وتوجيهها واستتمار ها بقدر

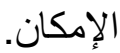

- - تهيئة المدارس لتلبية الاحتياجات الأساسية للأطفال ذوي الاحتباجات الخاصة بما يتطلب ذلك من إجر اء التعديلات البيئية الضرورية.

وتتطلب عملية تنفيذ هذه الأهداف من مديري مدارس التربية الخاصة تفهم أبعاد

التربية الخاصة حتي يستطيع أداء أدواره بكفاءة ويشكل محوراً رئيسياً يستند إليه تعليم

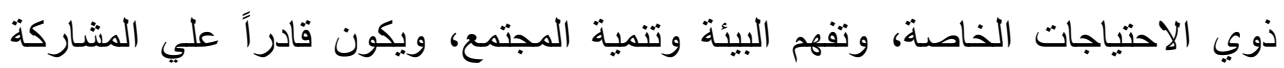
الفعالة في الأنشطة الاجتماعية، وتفهم جيداً مدخلات نظام تعليم ذوي الاحتياجات الخاصة ومخرجاته، وأن يكون متفهماً لفلسفة هذا التعليم و أهدافه وأبعاده الاجتماعية من أجل تهيئته

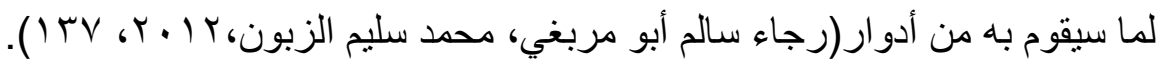
وبالرغم من اهتمام وزارة التربية والتعليم في مصر بمدارس التربية الخاصة للارتقاء بجودة الخدمة التعميمية بها، وتحسين بيئة العمل بمدارس التربية الخاصة، وتوقير بيئة عمل صحية، ومناخ تنظيمي إيجابي إلا أن مدارس التربية الخاصة في مصر تعاني من مشكلات عديدة شأنها شأن غير ها من المدارس، ويتمثل واقع مدارس

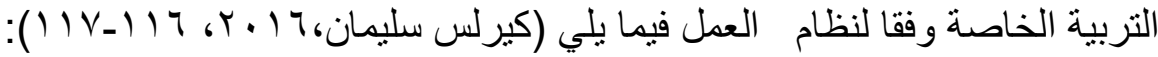
- عدم وجود فلسفة وأهداف استراتيجية ورؤية ورسالة واضحة لمدارس التربية

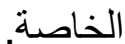

- ضعف وضوح أهداف رعاية ذوي الاحتياجات الخاصة، وضعف قابليتها للتنفيذ لدي العاملين في هذا المجال، حيث أن الأهداف التي وصفتها التربية والتعليم لم يطرأ عليها أي تغيير بالر غم من وجود المستحدثات التربوية. - عدم ملائمة بعض المباني المدرسية فمنها ما هو قديم ولا يفي بمتطلبات الجودة ولا تختلف مدارس ذوي الاحتياجات الخاصة عن المدارس العادية. 
- ضعف قدرة المديرين والمعلمين علي صباغة الرؤية والرسالة والأهداف الاستر اتيجية لمدارسهم.

- ـ حاجة المديرين و المعلمين لمدارس التربية الخاصة إلي اكتساب أفضل لمهارات التخطيط الاستر اتيجي.

- - عدم الفهح الواضح لمديري ومعلمي مدارس التربية الخاصة للمفاهيم المتعلقة بالتخطيط الاستر اتيجي.

- ضعف بر امج تأهيل وتدريب الكوادر البشرية بمدارس التربية الخاصة. - - قلة المشاركة المجتمعية في اتخاذ القرارات الاستر اتيجية التعليمية المتعلقة بفلسفة و إدارة مدارس التربية الخاصة.

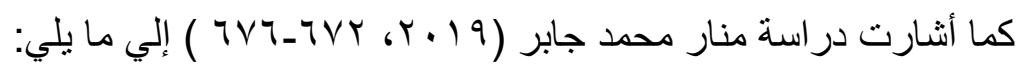
- وجود بعض القصور في بيئة العمل بمدارس التربية الخاصة وتجهيزاتها، وأن المدرسة لا تطور من التكنولوجيا المستخدمة في أداء مهامها وفقا لقدرات الأفراد ومتغيرات البيئة، ولا توفر التكنولوجيا التي تتوافق مع ذوي الاحتياجات الخاصة، ورلا تستفيد من قدر ات الأفر اد وبيئتها الفيزيقية في التعامل مع الأزمات و المخاطر. ـ قصور مدارس التربية الخاصة عن تقدير قدرات وكفاءات العاملين وجهودهم بصفة مستمرة وقلة تشجيعها للعاملين المبدعين بها علي تقديم أفكار متميزة في التعامل مع ذوي

$$
\text { الاحتباجات الخاصة. }
$$

ـ لا تهنم المدرسة بالبحث المستمر عن طرق جديدة لتطوير أساليب العمل وفقا لقدرات العاملين بها، وهناك قصور في حرص المدرسة علي توافق نظام العمل وقدرات العاملين، بما يعوقها عن الإبداع وما يحققه من جودة في الأداء وتميز العمل. - وجود قصور في مدي توافر متطلبات الإبداع التنظيمي بمدارس التربية الخاصة المصرية. 
تأهيل مديني مدارس التربية الخاصة بدحافظة البحر الأحمر في ضوء محددات الرشاقة الإستراتيجية

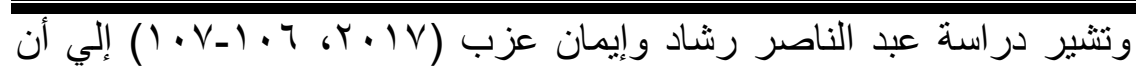

مدارس التربية الخاصة تعاني من أوجه قصور عدة منها: - الافتقار إلي رؤية ورسالة واضحيين لددارس التربية الخاصة وإن وجدا فتكونا في صورة شكلية دون الاهتمام بترجمنهما في العمل الددرسي أو السعي لتحقيقهما. - ضعف مشاركة المعلمين في التخطيط للأداء الددرسي. - قلة الإمكانات التعليمية والتجهيزات اللازمة في المباني والفصول و المعامل لضمان فاعلية عمليتي التعليم والتعلم كالوسائل التعليمية وحجر ات الدصادر. - - ضعف وضوح أهداف مدارس التربية الخاصة في أذهان القائمين علي إدارتها

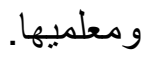
- - معف فعالية دور قادة الدارس في تهيئة المناخ الصحي المناسب للارتقاء بأداء

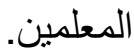

- ضعف امتلاك بعض قادة التربية الخاصة للكفايات المهنية و الإنسانية الأساسية. - - ضعف فعالية برامج التنمية المهنية لمعلمي مدارس التربية الخاصة وشكليتها وضعف الاهتمام فيها بتقييم احتياجاتهم التدريبية وتركيزها علي الجوانب النظرية دون الجوانب العملية التطبيقية. وتختلف طبيعة مهام ودور مديري مدارس الأطفال ذوي الاحتياجات الخاصة



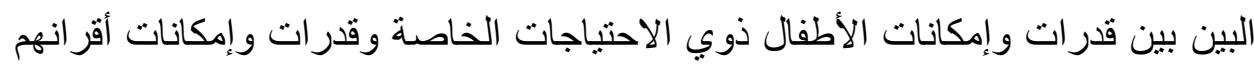

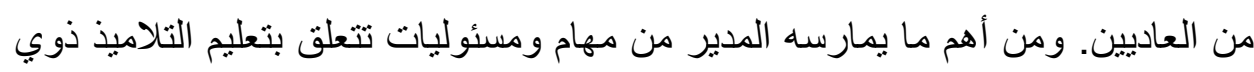

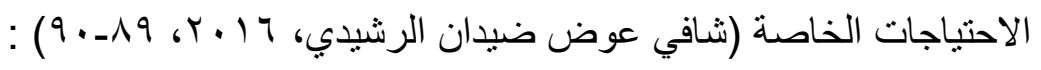

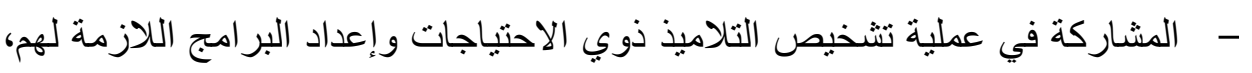
كأحد الأدوار التي تحددها القوانين الحكومية علي مدير لمي مدارس التربية الخاصة. 
- - توفير بيئة آمنة للتعلم للتلاميذ ذوي الاحتياجات الخاصة، وتهيئة مناخ تعليمي مناسب لهم يمكنهم من الاندماج مع أقر انهم العاديين في الأنشطة الصفية وغير الصفية. - - التأكد من تلقي كل تلميذ لجميع الخدمات الواردة في الخطة التربوية وتوفير التسهيلات المطلوبة لتقديم هذه الخطة و غير ها من الخدمات الإضافية. - - التأكد من اتمام عمليات التقييم وإعادة التقييم والمراجعات السنوية للتلاميذ ذوي الاحتباجات الخاصة بشكل ملائم وبما يتو افق مع القو انين و اللوائح. - وضع تفاصيل تطبيق المناهج الدراسية، حيث يقوم المدير بمساعدة المعلمين في تتسيق بر امج التربية الخاصة و الأنشطة الصفية العادية. - - تحديد المعايير والأهداف التربوية لبرامج التربية الخاصة، و التأكد من أن هذه البر امج تتو افق مع القوانين المحلية، حيث نجاح برامج التربية الخاصة يتوقف علي دور المدير ومدي دعمه و اهتمامه وخبرته الفنية. - - ادخال بعض التعديلات علي البرامج التعليمية بهدف تحسينها، فالمديرون لابد أن

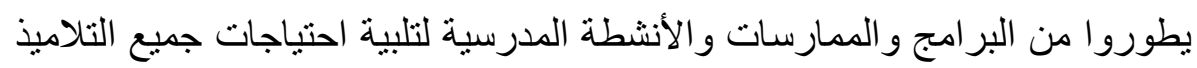
ذوي الاحتياجات الخاصة. ولكي يقوم مديري مدارس التربية الخاصة بهذه المهام يتطلب كفايات محددة وتكون أساس أية برامج تدرييية لتنمية وتطوير دور المدير. ويمكن تحديد الكفايات اللازمة لمديري مدارس التربية الخاصة وفقا لمهامهم كالتالي (شافي عوض ضيدان

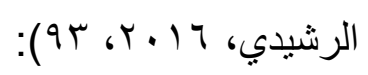
- معرفة التطبيقات العملية للمناهج الدر اسية المقدمة للأفر اد ذوي الاحتياجات الخاصة. - معرفة مبادئ المناهج وطرق التدريس، ومعرفة كيفية تصميم البرامج التدريبية، وتعليم وتوجيه الأفر اد و المجمو عات وقياس وتقييم نتائج التدريب. 
تأهيل مديزي مدارس التربية الخاصة بمحافظة البحر الأحمر في ضوء محددات الرشاقة الإستراتيجية - الالمام بأساليب و المبادئ المتعلقة بالنماذج والإجراءات التربوية والاستراتيجيات التي تساعد التلاميذ ذوي الاحتياجات الخاصة في الحصول علي تعلم جيد. - الالمام بكيفية التخطيط للمناهج وتحسينها، وتوفير المناهج الدراسية والبرامج الملائمة، وتهيئة المعلم لأن يكون معلم قابل للتعلم لاستيعاب الاستر اتيجيات و القدرة علي تصميمها، والتأكد من أن البرامج تلبي احتياجات التلاميذ وتقديم الأفكار المتعلقة بالمو ارد و التأكد من تو افر مصادر ها. - القدرة علي توفير الخطط والأساليب لتوقع الاتجاهات والمضامين التربوية المعاصرة، و القدرة علي تطوير وتنفيذ الإجر اءات المتعلقة بصياغة المناهج الملائمة

$$
\text { لهذه الاتجاهات الحديثة، و الإشر اف عليها. }
$$

وتتمثل أنواع التأهيل المقدمة من مديري مدارس التربية الخاصة في الآتي

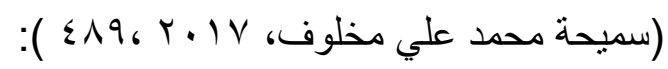

- - التأهيل النفسي لذوي الاحتياجات الخاصة: وهي مجموعة متكاملة من الخدمات المتخصصة بهدف مساعدة الفرد المعاق علي مواجهة المشكلات وتحديد أسبابها وفهمها لاتخاذ القرارات الملائمة من خلال فهم شخصية وقدراته لتحقيق أقصي درجة ممكنة من التكيف و العمل للوصول إلي مفهوم إيجابي للذات. - - التأهيل الاجتماعي لذوي الاحتياجات الخاصة: هي عبارة عن حزمة من الخدمات تعمل علي مساعدة الفرد علي التكيف و التعامل بشكل إيجابي بناءً مع المجتمع. - التأهيل الطبي لذوي الاحتياجات الخاصة: هي عملية استرجاع و إعادة لقدرات الفرد المعوق و علي أعلي مستوي وظيفي ممكن من الأداء من النواحي الجسدية أو العقلية بهدف تحسين الصحة العقلية والجسمية للمعوق ليقوم بنشاطه بفاعلية. 
- - التأهيل التربوي والأكاديمي لذوي الاحتياجات الخاصة: تعليم المعاقين أكاديمياً كل منهم حسب قدر اته ودرجة إعاقته الجسمية والعقلية وتزويدهم بالمهارات الأكاديمية اللازمة التي تفيدهم في حياتهم العملية.

- التأهيل المهني لذوي الاحتباجات الخاصة: هو جزء من حلقة متصلة من عملية التأهيل والتي تشمل توفير خدمات مهنية مثل: التوجيه المهني والتدريب المهني هني بهدف تمكين المعوق من ضمان عمل مناسب والاحتفاظ به، حيث تمر خدمات التأهيل المهني بمر احل الإحالة و التسجيل والإرشاد و التوجيه المهني. - خدمات التأهيل الثاملة: تتضمن عمليات تأهيل ذوي الاحتياجات الخاصة خدمات التأهيل الثناملة عدد غير قليل من الخدمات التي تتجه إلي مساعدة الطلبة علي استعادة أقصي درجة من درجات القدرة الجسمية والعقلية والاجتماعية والمهنية بهذف الحفاظ علي تكامل شخصية المعاق وإعادة قدراته وتأهيله اجتماعياً ونفسياً وجسمياً ومهنياً. ويتضح مما سبق أن مدارس التربية هي المسئولة عن متابعة البناء التربوي بما يتعلق بالطلاب ذوي الاحتباجات الخاصة، لتوصله إلى ما يتمناه المجتمع وتطمح إليه الأمة. وتحتاج مدارس التربية الخاصة، شأنها في هذا شان بقية المؤسسات إلى إدارة منظمة تقوم على أسس علمية، إذ أن تحقيق أهدافها يعتمد على كفاءة العمل الإداري،

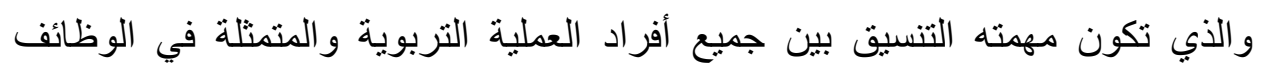
الإدارية والفنية التي مهنتها تحديد أهداف المؤسسة التعليمية وضبط ميز انيتها وتحديد مسؤوليات وواجبات العاملين فيها والاتصال والتتسيق مع أولياء الأمور، ومع الجهات الرسمية وغير الرسمية، ذات العلاقة بيرامج التربية الخاصة، كما تكون مهمة الإدارة

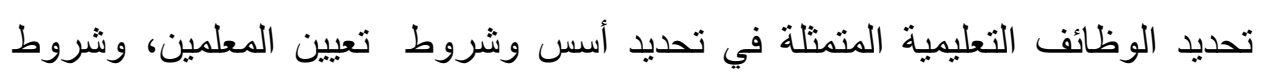
قبول الطلبة، وتنظيم حقوقهم، وتنظيم البرامج التربوية اليومية، و البرامج التربوية

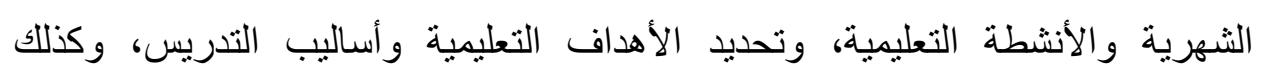


تأهيل مديزي مدارس التربية الخاصة بمحافظة البحر الأحمر في ضوء محددات الرثاقة الإستراتيجية

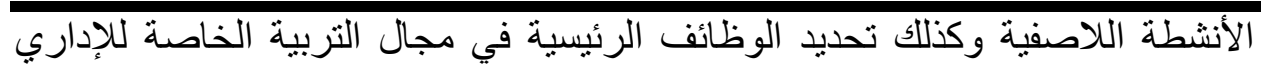
الفني، و المعلم.

رابعاً: واقع توافر محددات الرشاقة الاستراتيجية لدي مديري مدارس التربية الخاصة

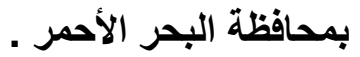

بعد الانتهاء من الإطار النظري للبحث، جاءت الدراسة الميدانية لتجيب عن السؤال البحثي الثاني:"ما واقع تو افر محددات الرشاقة الاستر اتيجية لدي مديري مدارس التربية الخاصة بمحافظة البحر الأحمر من وجهة نظر المعلمين والعاملين ؟"، ويمكن تناول الدر اسة الميدانية من حيث أهدافها و إجر اءاتها ونتائجها على النحو التالي: 1- - هدف الاراسة الميدانية: هدفت الدراسة الميدانية إلي التعرف علي مدي توافر محددات الرشاقة الاستر اتيجية لدي مديري مدارس التربية الخاصة بمحافظة البحر الأحمر من وجهة نظر المعلمين و العاملين، بما يساعد في بناء التصور المقترح. r- إجراعات الدراسة الميدانية وتتثل إجر اءات الدر اسة الميدانية ما يلي : أـ مجتمع وعينة الدراسة: تكون مجتمع الدراسة من جميع المعلمين و العاملين بمدارس التربية الخاصة التابعة لمحافظة البحر الأحمر ويوضح جدول ( ) إحصائية بأعداد المعلمين والعاملين بمدارس التربية الخاصة التابعة لمحافظة البحر الأحمر.

\begin{tabular}{|c|c|c|c|c|c|c|c|}
\hline العدد الكلي & \multicolumn{2}{|c|}{ مكفوفين } & \multicolumn{2}{|c|}{ تربية فكرية } & \multicolumn{2}{|r|}{ صم } & \multirow[b]{2}{*}{ مدن المحاقظة } \\
\hline & موظف & معلم & موظف & معلم & موظف & معلم & \\
\hline TE & $r$ & $\varepsilon$ & 0 & $\Lambda$ & $\varepsilon$ & 1. & رأس غارب \\
\hline 97 & 11 & iv & IT & $r$. & 7 & r. & الغردقة \\
\hline rᄉ & - & - & 0 & 11 & 1. & 1. & القصير \\
\hline Tr & - & - & 9 & 11 & - & - & سفاجا \\
\hline 19. & $1 \varepsilon$ & YI & M & os & $r$. & 0. & المجموع الكلي \\
\hline
\end{tabular}

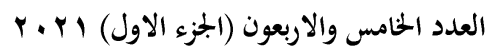

(220)

مجلة كلية التربية- جامعة عين شمس 
1- العينة الاستطلاعية : و عددها .7 فرداً ما بين معلم وموظف وذلك لفحص

$$
\text { الخصائص السيكومترية لأداة الدراسة . }
$$

r- العينة الأساسية : وتكونت من( • (1) فرداً ما بين معلم وموظف إجمالي ( • (1) فرداً بنسية 1 7٪، وهي نسبة ملائمة لطبيعة الدراسة عند مستوي ثقة 0.95 وفقًا لمعادلة ريتشارد جيجر. ب- أداة الدراسة الميدانية (استبانة) وتشمل أداة الدر اسة ما يلي: بناء أداة الدر اسة ( الاستبانة)

بعد الاطلاع علي البحوث والدراسات التربوية المتعلقة بالرشاقة الاستر اتيجية، تم الاستعانة بالاستبيان كأداة للار اسة المبدانية، حيث يتم استخدامه من قبل في البحوث التربوية على نطاق واسع من أجل الحصول على حقائق عن الظروف القائمة بالفعل من المعايثين أو المشاركين لذا وضعت أداة الدراسة لتقيس الممارسات القيادية لمديري مدارس التعليم العام في ضوء محددات الرشاقةالاستر اتيجية من وجهة نظر (المعلمين و العاملين)، من خلال وضع قائمة بأهم الممارسات القيادية للإدارة المدرسية تتكون من فقرة (ممارسة قيادية) موزعة إلى أربع محددات رئيسة هى: (VI) الاستراتيجية، سيولة الموارد، وحدة القيادة، التكنولوجيا. وطبقاً لمقياس ليكرت الخماسي فقد تم تحديد أوزان فقرات الاستبان حيث تم إعطاء خمس نقاط للإجابة أوافق بشدة ، و إعطاء أربع نقاط للإجابة ، وثلاث نقاط للإجابة محايد وتقطتين للإجابة لا أوافق، في حين تم إعطاء نقطة و احدة للإجابة لا أو افق بثدة. تقنين أداة الدر اسة ( الثبات و الصدق)

(أ) الصدق:

وتم قياس صدق أداة الدراسة بواسطة: 
تأهيل مديزي مدارس التربية الخاصة بمحافظة البحر الأحمر في ضوء محددات الرشاقة الإستراتيجية - صدق الاتساق الداخلي: تم اختيار أفر اد عينة الدراسة الاستطلاعية مكونة من

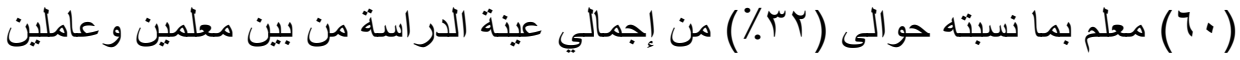
مدر اس التربية الخاصة والتي تقع جميعها في نطاق محافظة البحر الأحمر، بالإدارات

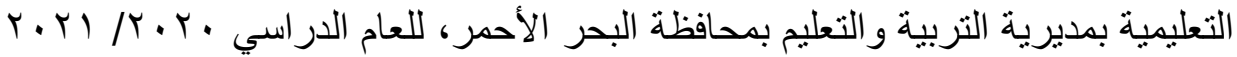
تم اختيار هم عشوائياً مسن مجتمع الدراسة طبقت الاستبانة عليهم، وجدول رقم ( ) يوضح ذللك.

- - الاتساق الاخلى للاستبانة ما بين مفردات كل محور والمحور نفسه:

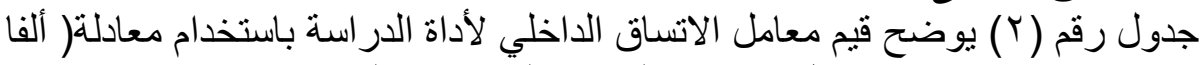

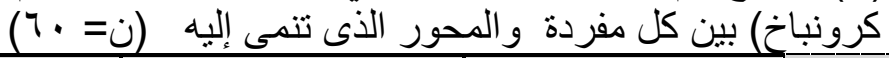

\begin{tabular}{|c|c|c|c|c|c|c|c|}
\hline \multicolumn{2}{|c|}{ المحور الرابع الاتساق } & \multicolumn{2}{|c|}{ المحور الثالث الاتساق } & \multicolumn{2}{|c|}{ الاتساق الداخلّي الثاني } & \multicolumn{2}{|c|}{ المحور الأول الاتسـاق } \\
\hline قألفا كرونباخ معامل & المفردة & قألفا كرونباخ معامل & المفردة & قألفا كرونباخ معامل & رقم & قألفا كرونباخ معامل & المفردة \\
\hline$* *,, 79 V$ & 1 & $* *, V \leq V$ & 1 & **, , Vフ & 1 & $* *, 797$ & 1 \\
\hline$* *, \lambda \cdot r$ & $r$ & $* *,, 7, T$ & $r$ & $* *, 0 r Y$ & r & $* *,, \vee \vee q$ & $r$ \\
\hline$* *, V Y r$ & $r$ & **, oV & $\Gamma$ & $* *,, \vee 79$ & $r$ & $* *,, T \wedge V$ & r \\
\hline$* *, 7 T$ & $\varepsilon$ & $*_{*}, \wedge Y \mu$ & $\varepsilon$ & $* *,, V \vee r$ & $\varepsilon$ & $* * \cdot, \wedge \Gamma$ & $\varepsilon$ \\
\hline$* *, \wedge \vee 0$ & 0 & $* *,, \vee q \varepsilon$ & 0 & **, , Ү^. & 0 & $* *,, V \leqslant Y$ & 0 \\
\hline$* *, 719$ & 7 & $\left.*^{* *}, 7\right\} \leq$ & 7 & **, , V० & 7 & $* *,, V \wedge r$ & 7 \\
\hline$* *, \Lambda \cdot \varepsilon$ & $\checkmark$ & $* *, 1<79$ & V & $* *,, V \leqslant r$ & V & $* *, \Lambda, \mu$ & V \\
\hline$* *, 70$. & $\Lambda$ & $* *,, 7 \leq 7$ & $\Lambda$ & $* *,, \circ \vee$. & $\wedge$ & $* *,, \vee \vee q$ & $\Lambda$ \\
\hline$* *, \wedge \Gamma$. & 9 & ${ }^{* *},, \Lambda \mid V$ & 9 & $* *,, v \leqslant 0$ & 9 & $* *,, \vee r q$ & 9 \\
\hline$* *, V{ }^{*} 0$ & 1. & $* *,, T \leq r$ & 1. & $* *,, \vee \wedge I$ & 1. & $* *, \wedge$, & 1. \\
\hline${ }^{* *}, \wedge \ldots$ & 11 & $* *,, \wedge \leq r$ & 11 & **, , $\wedge 91$ & 11 & $* *, \wedge M$ & 11 \\
\hline$* *,, \vee 9 \leq$ & IT & $* *,, \wedge \circ Y$ & $1 Y$ & **, , ITI & IT & **, , $\wedge \Gamma$. & IT \\
\hline$* *, 794$ & 11 & $* *,, 794$ & 11 & $* *,, 797$ & $1 T$ & $* *,, 791$ & iT \\
\hline$* *,, \vee \vee q$ & $1 \varepsilon$ & $* *,, \vee \vee q$ & $1 \varepsilon$ & $* *,, \vee \vee q$ & $1 \varepsilon$ & $* *,, \vee \vee q$ & $1 \varepsilon$ \\
\hline$* *,, \neg \wedge \vee$ & 10 & $* *,, \backslash \wedge V$ & 10 & $* *,, \nearrow \wedge V$ & 10 & $* *,, \uparrow \wedge V$ & 10 \\
\hline$* *, 7 T 1$ & 17 & & & **, , $\wedge M$ & 17 & **.,人ץI & 17 \\
\hline
\end{tabular}

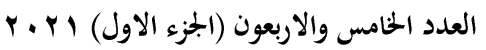

(222)

مجلة كلية التربية- جامعة عين شمس 
د. رجب أحمد عطا محمد

\begin{tabular}{|c|c|c|c|c|c|c|c|}
\hline \multicolumn{2}{|c|}{ المحور الرابع الاتساق } & \multicolumn{2}{|c|}{ المحور الثالث الاتساق } & \multicolumn{2}{|c|}{ الاتساق الداخلّي } & \multicolumn{2}{|c|}{ المحور الأول الاتساق } \\
\hline قألفا كرونباخ معامل & المفردة & قألفا كرونباخ معامل & المفردة & ألفا كرونباخ معامل & رقمرد & قألفا كرونباخ معامل & المفردة \\
\hline$* *,, 794$ & IV & & & & & $* *, 0 \leqslant Y$ & iv \\
\hline$* *,, \vee \vee q$ & 11 & & & & & $* *, 0 \wedge r$ & 11 \\
\hline & & & & & & $* *, \Lambda, \mu$ & 19 \\
\hline & & & & & & $* *,, \vee \vee q$ & $r$. \\
\hline & & & & & & $* *, 7 \mu q$ & Y \\
\hline & & & & & & $* *,, \vee 99$ & Tr \\
\hline
\end{tabular}

* *وجد دلالة إحصائية عند مستوى (1 ( , • (•)

يتضح من الجدول السابق أن جميع معاملات الاتساق الداخلي ألفا كرونباخ دالة إحصائياً ما بين مفردات كل بعد و البعد نفسه.

- الاتساق الداخلى للاستبانة ما بين محاور الاستبانة والمجموع الكلى للاستبانة جدول رقم (r) يوضح قيم معامل الاتساق الداخلي لأداة الدر اسة باستخدام معادلة( ألفا كرونباخ) بين كل مجال و الدرجة الكلية لأداة الدر اسة استبانة الرشاقة الإستر اتيجية (ن= • ؟7)

\begin{tabular}{|c|c|}
\hline \multicolumn{2}{|c|}{ الاستبانة ككل الاتساق الداخلى } \\
\hline قيمة معامل الفا كرونباخ & المحدد \\
\hline$* *, \wedge 07$ & المحدد الأول الحساسية الإستر اتيجية \\
\hline$* *, \wedge) \wedge$ & المحدد الثاني سيولة الموارد \\
\hline$* *,, \vee \wedge 9$ & المحدد الثالث وحدة القيادة \\
\hline$* *, 771$ & المحدد الر ابع التكنولوجيا \\
\hline
\end{tabular}

العدد الخامس والاربعون (الجزء الاول) ا ب. r.

(223)

جلة كلية التربية- جامعة عين شثس 
تأهيل مديني مدارس التربية الخاصة بحافظة البحر الأحمر في ضوء محدات الرشاقة الإستراتيجية

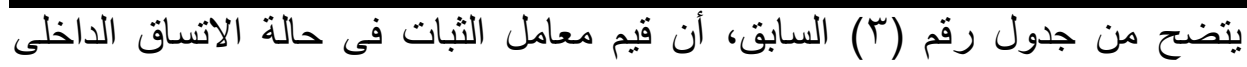

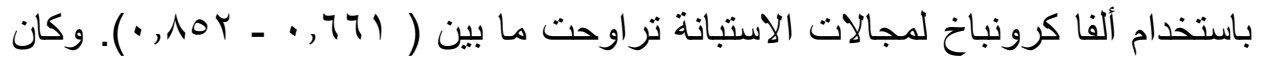
ارتباط المحور الأول الحساسية الإستراتيجية بالكل (107 • •)، وارتباط الدحور الثاني

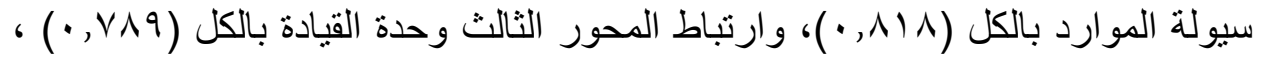

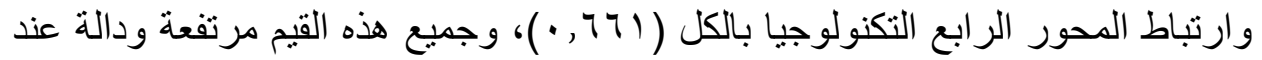
مستوى ( ا . • ) مما يشير إلى قوة ثبات محاور أداة الدراسة وأيضاً ثبات أداة الدراسة ككل ومن ثم صلاحيتها للنطبيق. فمن الناحية النطبيقية تعد القيمة (من 7 . , • فما فوق) لمعامل (ألفا كرونباخ) معقولة في البحوث المنعلقة بالإدارة و العلوم الإنسانية.

\section{- - مدق المقارنة الطرفية}

قام الباحث بترتيب أفر اد العينة الاستطلاعية والبالغ عددهم ( • (7) مفحوصا ترتيباً تنازلياً

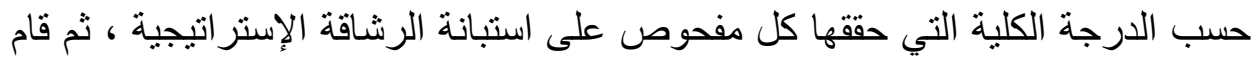

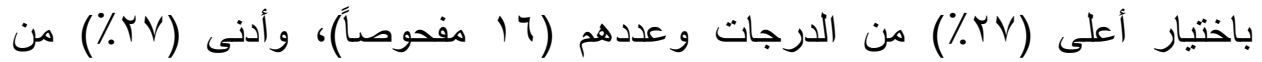
الدرجات وعددهم (17 مفحوصاً)، وتم إجراء المقارنة بين درجات المجموعتين باستخدام اختبار "ت"؛ وذلك لكون عدد الأفراد في كل مجموعة يساوي (7) 17 مفحوصاً)، وهو عدد كبير يجوز معه استخدام اختبار بارامتري كاختبار (ت)، بالإضافة لكون اختبار(ت) مصمم للتوزيعات الكبيرة، الدتجانسة منها وغير المتجانسة.

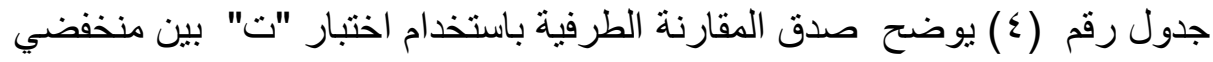
ومرتفعي الدرجات على استبانة الرشاقة الإستر اتيجية

\begin{tabular}{|c|c|c|c|c|c|}
\hline مستوى الدلالة & قيمة "ت" & الالحعراف & الحسابى المط & الفئة (ن= 14 ) & الأداءة \\
\hline \multirow{2}{*}{$\cdot, \ldots$} & \multirow{2}{*}{$* *_{0}, T \vee 1$} & $Y Y, \cdot V$ & $1 \leqslant 0,94$ & منخفضو الأداء & ستبانة الرشاقة \\
\hline & & $\varepsilon 0, \ldots$ & $r \mid V, \ldots$ & مرتفعو الأداء & الإستر اتيجية \\
\hline
\end{tabular}

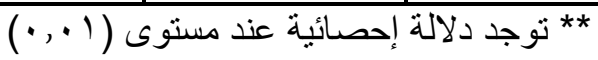


وتم قياس ثبات أداة الدراسة بواسطة :

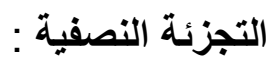
تم حساب ثبات المقياس بين درجات العبارات الفردية والعبارات الزوجية عن طريق معادلة سيبرمان بروان، وذلك على مجموعة من معلمين وعاملين مدراس التربية الخاصة والني تقع جميعها في نطاق محافظة البحر الأحمر، بالإدارات التعليمية بمديرية

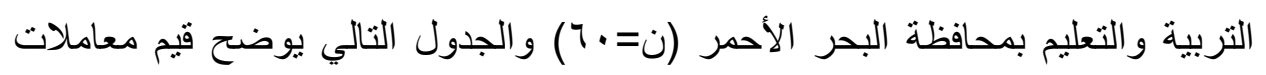

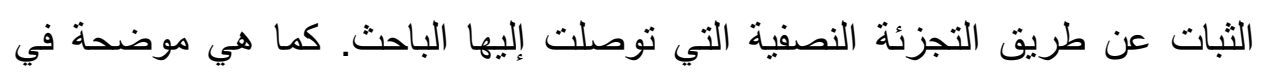

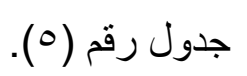

جدول رقم (0) يوضح قيم معاملات الارتباط بين درجات العبار ات الفردية والعبارات

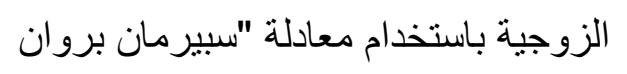

\begin{tabular}{|c|c|c|}
\hline معامل الارتباط (الثبات) بعد التصحيح & معامل الارتباط (الثبات) & الأبعــاد \\
\hline$* *_{*}, \wedge \uparrow q$ & $\cdot, V \cdot V$ & المحدد الأول \\
\hline${ }^{* *} \cdot, \lambda r$. & $\cdot, v \cdot q$ & الححدد الثانى \\
\hline$\star_{* *}^{*}, \wedge \wedge 1$ & $\cdot, \mathrm{VA \Lambda}$ & المحدد الثالث \\
\hline$*_{*}^{*}, \lambda \leqslant 9$ & $\cdot, V \Gamma \wedge$ & المحدد الرابع \\
\hline
\end{tabular}

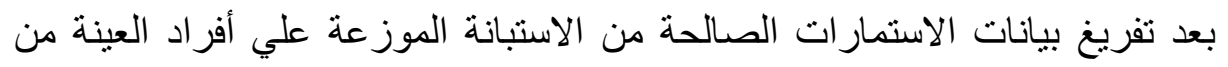

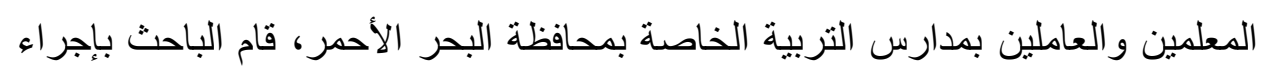

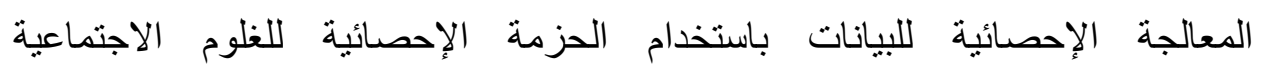


تأهيل مديري مدارس التربية الخاصة بححافظة البحر الأحمر في ضوء محدات الرشاقة الإستراتيجية Statistical Package for Social Science (SPSS) - - استخدام المتوسطات الحسـابية، والانحر افـات المعياريـة لمعرفـة إجابـات أفراد الدر اسـة تجاه محاور أداة الدراسة. - - استخدم الباحث للإجابة و التصحيح تدريج ليكرت الخماسي في الاستبيان، ويوضح الجدول التالي درجة القطع لفئات الدرجات لكل مسنوى من مستويات الدراسة. جدول (7) درجة القطع ومستويات التقدير لاستجابات المعلمين و العاملين بمدارس التربية الخاصة بمحافظة البحر الأحمر.

\begin{tabular}{|c|c|c|}
\hline درجة القيام بالدور & النسبة المئوية & فئات الدرجات \\
\hline درجة عالية جدًا & 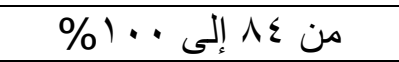 & من r, ع إلى 0 \\
\hline درجة عالية & من ^^ج إلى أقل من \&^^\% & من ؟, ؟ إلى أقل من Y, ؟ \\
\hline درجة متوسطة & من Yo إلى أقل من \\
\% & من T, T إلى أقل من 乏,r \\
\hline درجة منخفضة & من צT إلى أقل من O \% \% & من ^, 1, إلى أقل من ؟, r \\
\hline درجة منخفضة جدًا & من · إلى أقل من צץ\% & من 1 إلى أقل من ^, 1, \\
\hline
\end{tabular}
- - استخدم معامل ألفا كرونباخ لحساب الاتساق الدخلى للاستبانة. - - استخدام التجزئة النصفية لسبيرمان بر اون لحساب ثبات الاستبانة. - اختبار T.Test لحساب صدق الاستبانة من خلال استخدام صدق المقارنة الطرفية ع- اجراءات التطبيق تمثلت إجر اءات تطبيق الاستبانة في الخطوات التالية: - - توزيع استمارات الاستبانة علي أفراد العينة من فئة المعلمين والعاملين بمدارس التربية الخاصة بمحافظة البحر الأحمر. - - تجميع استمار ات الاستبانة بعد توزيعها، و استبعاد بعض الاستمار ات غير الصالحة . 
د. رجب أحمد عطا محمد

هـ نتائج الدراسة الميدانية ( تحليلها وتفسيرها)

للإجابة عن السؤال الثالث والذى نصه:"ما واقع توافر محددات الرشاقة الاستراتيجية لاي مديري مدارس التربية الخاصة بمحافظة البحر الأحمر من وجهة نظر المعلمين لهربه و العاملين ؟، بعد إجراء المعالجات الإحصائية للبيانات، ثم رصد النتائج في صورة جدو ال إحصائية وتفسير ها علي النحو التالي: - - نتائح الدراسة الخاصة بواقع توافر محددات الرشاقة الاستراتيجية لدي مديري مدارس التربية الخاصة بمحافظة البحر الأحمر من وجهة نظر المعلمين و العاملين: - - ولتحقيق ذلك تم حساب المتوسط الحسابى، والانحراف المعيارى لكل فقرة (ممارسة) من الفقرات الواردة فى أداة الدراسة، التى تقيس توافر محددات الرشاقة الاستر اتيجية لاي مديري مدارس التربية الخاصة بمحافظة البحر الأحمر من وجهة

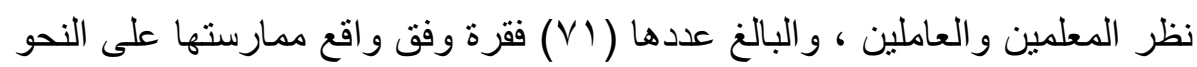
التالي:

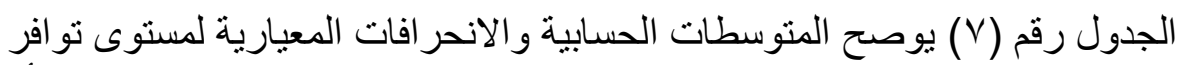

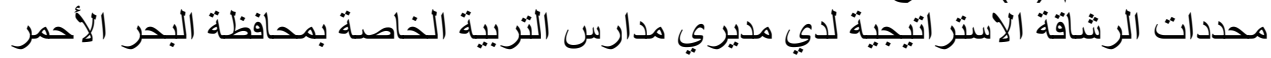
من وجهة نظر المعلمين و العاملين في كل محدد من محددات الرشاقة الاستر اتيجية.

\begin{tabular}{|c|c|c|c|c|c|c|}
\hline الترتيب & التو افر & الانحر افياري & الحستوسطي الحسبي & العدد & المحددات & العبار ات \\
\hline 1 & منخفضة & $\cdot, \vee \vee q$ & $Y, O V$ & $1 \%$. & المحدد الأول : الحساسية & TY-I \\
\hline$\Gamma$ & منخفضة & $\cdot, \lambda r$ & $r, \leqslant q$ & $1 \%$. & المحدد الثاني : سيولة & $\Gamma \wedge-r r$ \\
\hline$r$ & منخفصة & $\cdot, \wedge r$ & $r, 0$. & IT. & المحدد الثالث: وحدة & or-rq \\
\hline$\varepsilon$ & منخفضة & $\cdot, \lambda I$ & $Y, \leqslant 7$ & $1 \%$. & التحدد الرابع : التكنولوجيا & $V 1.0 \leqslant$ \\
\hline \multicolumn{2}{|c|}{ منخفضة } & $\cdot, \wedge$. & Y,o. & $1 \%$ & المحددات مجتمعة & \\
\hline
\end{tabular}

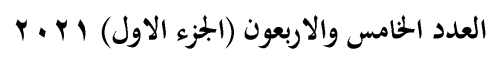

(227)

جلة كلية التربية- جامعة عين شثس 


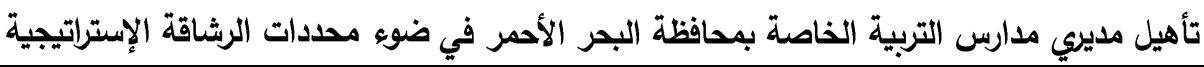
ويتضح من الجدول السابق أن المتوسط الكلي لمحددات الرشاقة الاستر اتيجية

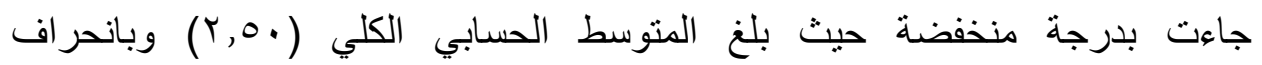

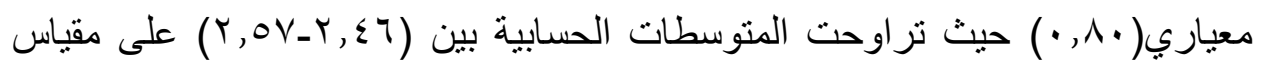
ليكرت الخماسي، والذي يثير إلى واقع الممارسة المنفض لمحددات الرشاقة

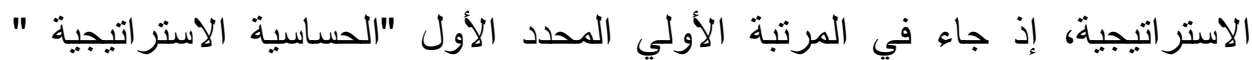

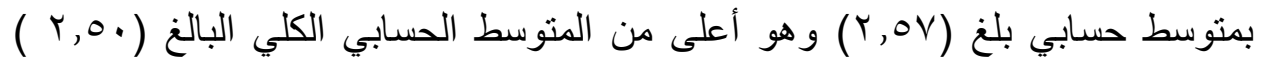

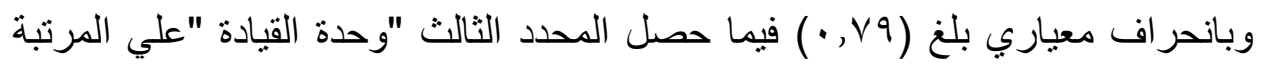

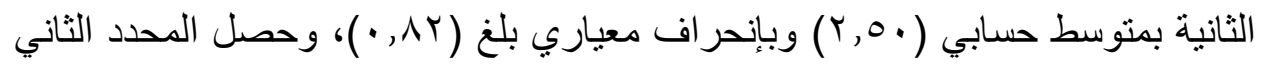

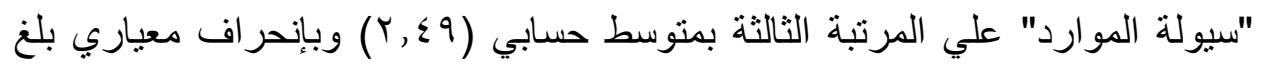

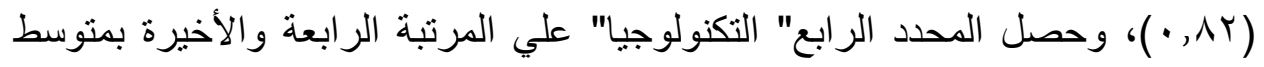

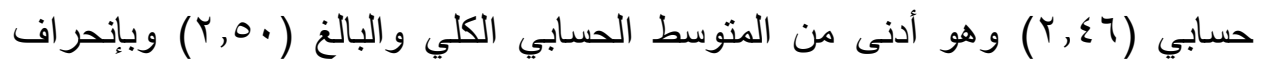

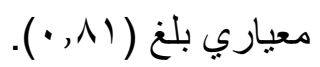

ويري الباحث أن النتائج السابقة تعني أن مديري مدارس التربية الخاصة بالبحر

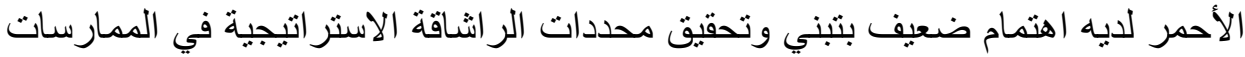
الإدارية والفنية ، ويمكن أن يكون السبب لهذه النتيجة ضعف قدرة مديري مدارس التربية الخاصة بالبحر الأحمر علي استثراف المستقبل والتتبؤ به، وامتلاك رؤية ورسالة غير واضحتين ومن ثم عدم القدرة علي تحويلهما لواقع ملموس عبر خطة كاملة، ولا يمتلك مديري مدارس التربية الخاصة سرعة الاستجابة الواضحة للتغيرات

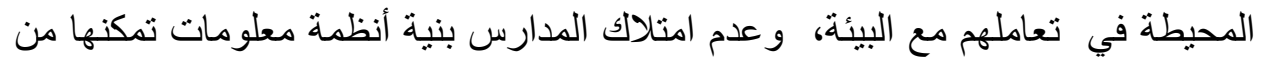

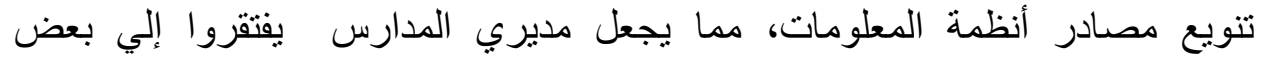
الثجاعة لاتخاذ قرارات صعبة وغير تقليدية عندما تكون هناك حاجة إليها.

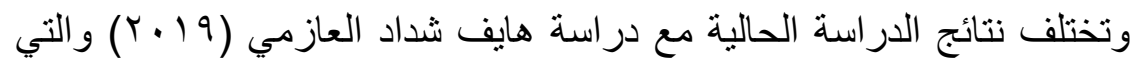
توصلت إلي أن مديري المناطق التعليمية في دولة الكويت يمارسون الرشاقة 
د. رجب أحمد عطا محمد

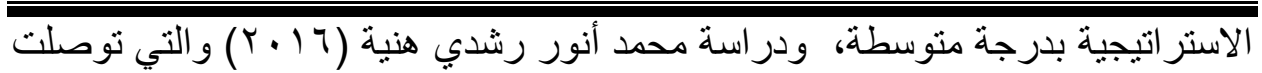
إلي أن مستوي ممارسة الرشاقة الاستراتيجية في شركات الصناعات الغذائية كانت بدرجة قوية مما أدي إلي تحقيق التميز في الأداء المؤسسي ، ودراسة محمد الراشد

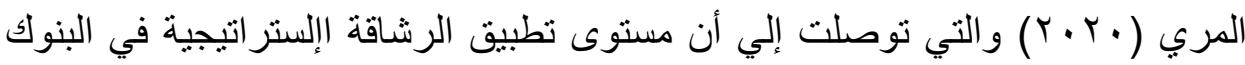

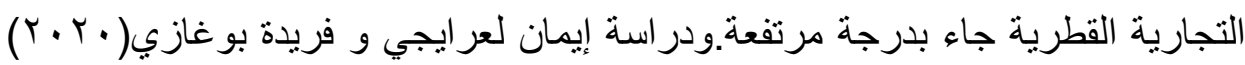
و التي توصلت إلي أن مستوى الرشاقة الاستر اتيجية منوسط. ودراسة (2017) Nikoo Tabe Khoshnood\&Sina Nematizade التي توصلت إلي أن ممارسة الرشاقة الاستراتيجية في القطاع المصرفي كانت بنسبة مرتفعة، ودر اسة (2020) Muhammad K. Hamdan, et.al و التي توصلت إلي أن مستوي ممارسة الرشاقة الاستر اتيجية كان بدرجة مرتفعة في المنظمات الأهلية Atallah Mohammed Tayser Alsharah الفلسطينية في قطاع غزة ، ودر اسة (2020) والتي توصلت إلي أن ممارسة محددات الرشاقة الاستر اتيجية كانت بدرجة مرتفعة وكان لها تأثثر إيجابي علي تميز الأداء المؤسسي في المؤسسات الحكومية في المملكة الأردنية الهاثمية.

ويمكن توضيح ذلك بالتفصيل لكل محدد من محددات الرشاقة الاستراتيجية على النحو التالي. بعد إجر اء المعالجات الإحصائية للبيانات، ثم رصد النتائج في صورة جدو ال إحصائية وتفسير ها علي النحو التالي:استجابات أفراد العينة نحو أبعاد الاستبانة وسيتم التعليق علي أعلي استجابيتن و أقل استجابتين لعينة الدراسة، وذلك في الأبعاد الأربعة التالية:

أ- نتائج خاصة بالبعد الأول ( الحساسية الاستر اتيجية)

الجدول رقم (^) يوضح المتوسطات الحسابية والانحر فات المعيارية ودرجة التو افر لاستجابات العينة ككل علي العبارات في البعد الأول الخاص بالحساسية الاستر اتيجية. 
تأهيل مديري مدارس التربية الخاصة بمحافظة البحر الأحمر في ضوء محددات الرثاقة الإستراتيجية

\begin{tabular}{|c|c|c|c|c|c|c|}
\hline الترتيب & التوافر & الانحراف المعياري & المتوسط الحسبي & العدد & العبار ات & a \\
\hline 7 & منوسطة & $1, r \wedge$ & $r, r$ & $1 \%$ & تلأنشتلكة إدارة المستقبلية لمو اجهة رؤية والتحديات & 1 \\
\hline 1. & متوسطة & سז, & $r, 90$ & IT. & 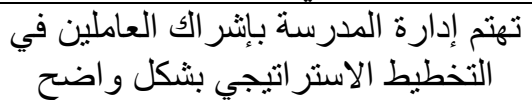 & r \\
\hline V & متوسطة & $1, \pi \wedge$ & $r, \cdot r$ & r. & تبذل إدارة المدرسة جهوداً منو اصلة & r \\
\hline r & منوسطة & 1,1 & r, & 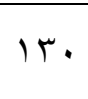 & تستفيد إدارة المدرسة من خبر اتها & $\varepsilon$ \\
\hline$\wedge$ & منوسطة & . & $r, \cdot 1$ & r. & تمتللك إدارة المدرسة آليات و أساليب & 0 \\
\hline$\varepsilon$ & منوسطة & $1, r r$ & r. & IT. & التمتع إدارة المدرسة بالقدرة علي تحديد التهديد بطدة جديدة & 7 \\
\hline rr & منخفضة & 1,19 & $r, A$ & IT. & تتمتع إدارة المدرسة بألقدرة الألقام الأهداف علي & V \\
\hline Tו & منخفضة & מז, & $Y, Y_{1}$ & IT. & 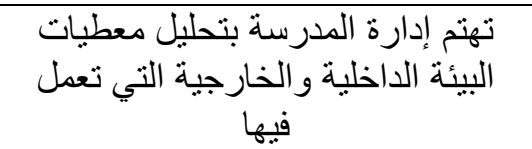 & $\Lambda$ \\
\hline 11 & منخفضة & $1, r$. & $r, r_{0}$ & IT. & استغلالل إدلارة المدرسة القدرة علي الإمكانات المتاحة & 9 \\
\hline $1 \leq$ & منخفضة & $1, Y 1$ & $r, Y)$ & IT. & 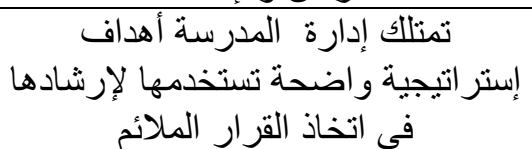 & 1 . \\
\hline YI & منخفضة & 1,10 & $r, \Lambda$ & IT. & تمتللك إدارة المدرسة تحليل عمل & 11 \\
\hline$r$. & منخفضة & 1,17 & $r, .9$ & IT. & يتطلع مدير المدرسة إلي استكثناف & IT \\
\hline 0 & منوسطة & $1, r V$ & r. 0 & Ir. & للمهار ات و المتلك إدارة المدرة الضرة الفهم الجيدة لمرورية لإنجاز & $1 \%$ \\
\hline r & منوسطة & 1,11 & r, & r. & 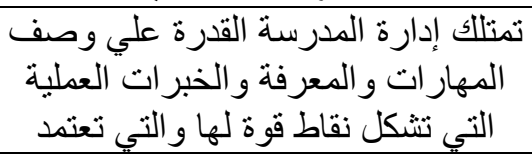 & $1 \varepsilon$ \\
\hline
\end{tabular}

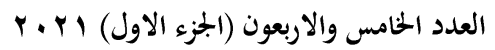

(230)

جلة كلية التربية- جامعة عين شمس 
د. رجب أحمد عطا محمد

\begin{tabular}{|c|c|c|c|c|c|c|}
\hline الترتيب & 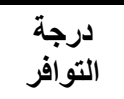 & الانحراف المعياري & المتوسط الحسبي & العدد الع & العبار ات & b \\
\hline & & & & & عليها للحفاظ علي استمر ارها & \\
\hline 1 & متوسطة & $1, r V$ & r, & ז. & تهنم إدارة المدرسة بالتحسين المستمر & 10 \\
\hline 9 & متوسطة & סש, 1 & $r, 99$ & Ir. & 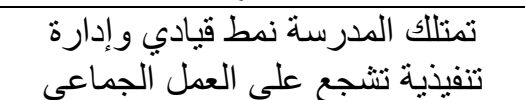 & 17 \\
\hline 10 & منخفضة & $1, r Y$ & $r, 1 \wedge$ & ir. & 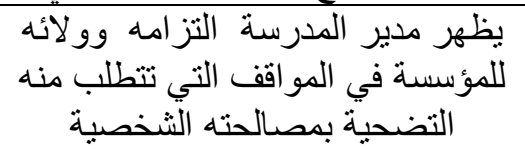 & iv \\
\hline it & منخفضة & سז, & $r, Y r$ & ir. & تعزز إدارة المدرسة قدرة العاملين على الفورية لمتغير اتلة البئة & 11 \\
\hline 17 & منخفضة & $1, r \leqslant$ & $r, 17$ & Ir. & الإستر اتيجية لاستدامة الميزة المدرة المهار اتنافسية & 19 \\
\hline 19 & منخفضة & 1,1 . & $r, I r$ & ז. & 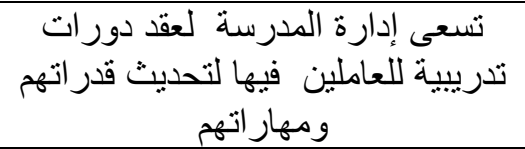 & r. \\
\hline iv & منخفضة & 1,17 & $r, 10$ & Ir. & 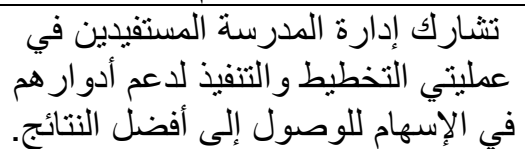 & Y) \\
\hline 11 & منخفضة & $1, r 7$ & $r, I r$ & ir. & بقدم مدير المدرسة الداعم و التشجيع أفدار جديدة & rt \\
\hline 1 & منخفضة & $\cdot, \vee 9$ & $r, \bullet V$ & ir. & المحدد الأول : الحساسية الإستراتيجية & \\
\hline
\end{tabular}

ويظهر من الجول السابق:

أن العبارة (0 10) و التي تتص علي " تهنم إدارة المدرسة بالتحسين المستمر لأدائها"

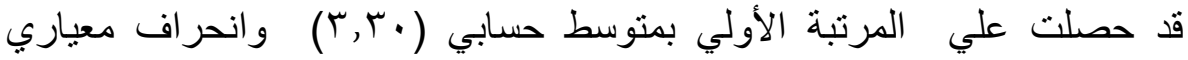
( ) , rV ) التكيف مع المتغيرات البيئية الداخلية والخارجية بشكل أكثر كفاءة ومرونة من ذي قبل، وسعيها إلي تحقيق الجودة والتوافق مع معايير الاعتماد لمدارس التربية الخاصة في ضوء رؤية • • ·r، وجود لجان متابعة وتقييم بالإدارات ومديريات التربية و التعليم بالمحافظة. 
تأهيل مديني مدارس التربية الخاصة بحافظة البحر الأحمر في ضوء محددات الرشاقة الإستراتيجية

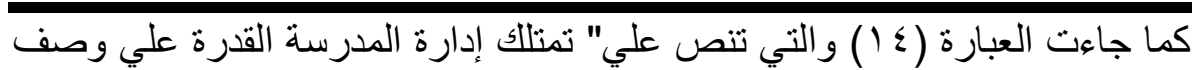
المهارات والمعرفة والخبرات العملية التي تثكل نقاط قوة لها والتي تعنمد عليها

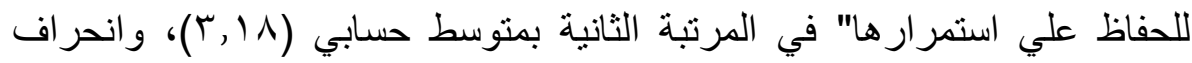
معياري (1, 1, (1)، وقد يرجع ذلك إلي اهتمام مديري الددارس دائما بالتركيز علي إظهار نقاط القوة ، و إغفال نقاط الضعف وعدم إظهارها أو معرفة الأسباب التي التي أدت إليها ومعالحتها بطريقة علمية واطغال كما جاءت العبارة (') والتي تتص علي" تمتلك إدارة الددرسة تحليل عمل

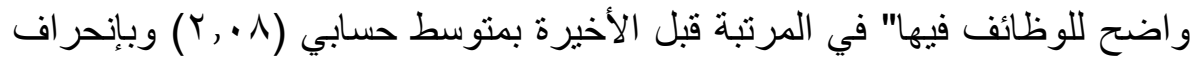
معياري (10) (1,)، مما يثير إلي إخفاق مديري المدارس في استخدام الأساليب العلمية لتحديد منطلبات كل وظيفة من وظائف العاملين بها سواء في الناحية الإدارية أو الفنية، ولا توفر لجميع العاملين توصيف واضح لمهامهم وأدوارهم ، مما يترتب علي ذلك عدم وضع الثخص المناسب في المكان المناسب . كما جاءت العبارة (V) و التي تنص علي" تتمتع إدارة الددرسة بالقدرة علي تحديد العو ائق أمام الأهداف الإستراتيجية بسر عة" في المرتية الأخيرة وقد برجع ذللك إلي لئي محدودية قدرة مديري المدارس علي التفكير الاستراتيجي كأحد أهم متطلبات التخطيط الاستراتيجي. وخلاصة ماسبق، يتضح أن العبارات المتعلقة بالمحد الأول" الحساسية الاستر اتيجية" من محدات الرشاقة الاستراتيجية علي النحو المجمل في الددي الضعيف بمتوسط حسابي (Y,OV)، وقد يرجع ذللك إلي اهتمام محدود من قبل مديري الددارس الخاصة بالبحر الأحمر بأهمية الانفتاح والاستبصار علي قدر كبير من المعلومات والخبرات من خلال الحفاظ علي العلاقات مع مجمو عة متتو عة من الأفراد والهنظمات. بـ نتائج خاصة بالبعد الثاني ( سيولة الموارد) 
د. رجب أحمد عطا محمد

يوضح الجدول رقم (9) المتوسطات الحسابية والانحرفات المعيارية ودرجة التو افر

لاستجابات العينة ككل علي العبارات في البعد الثاني الخاص بسيولة الموارد.

\begin{tabular}{|c|c|c|c|c|c|c|}
\hline الترتيب & التوافرة & الانحراف & الحستوسط & العدد & العبارات & 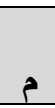 \\
\hline 7 & متوسطة & $1, Y T$ & $r, \vee q$ & $\pi$. & الموم إدارة المداءً على المنطلة بمواءمة المبنة & 1 \\
\hline r & متوسطة & 1,11 & $r, 19$ & $1 \pi$. & 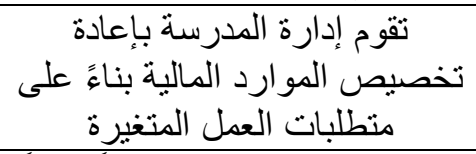 & r \\
\hline 1 & متوسطة & $1, r V$ & $r, r$. & $\pi$. & 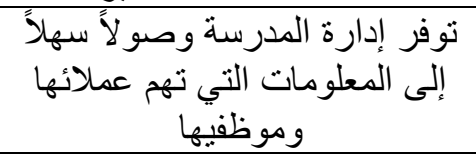 & $r$ \\
\hline$r$ & متوسطة & $1, \Gamma \wedge$ & $r, \cdot \Lambda$ & $1 \pi$. & 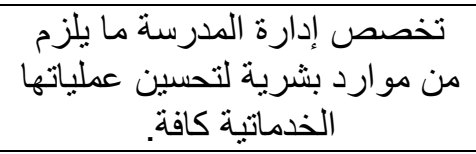 & $\varepsilon$ \\
\hline 0 & متوسطة & $1, r$ & $r, \cdot 1$ & $\pi$. & 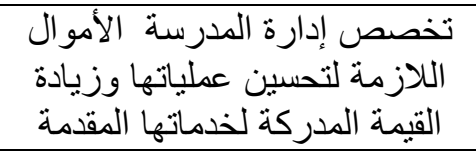 & 0 \\
\hline$\varepsilon$ & متوسطة & $1, r r$ & $r, \cdot T$ & $\pi$. & 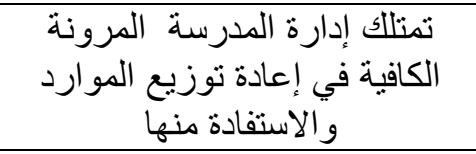 & 7 \\
\hline 10 & منخفضة & 1,19 & $r, \cdot \Lambda$ & $1 \pi$. & 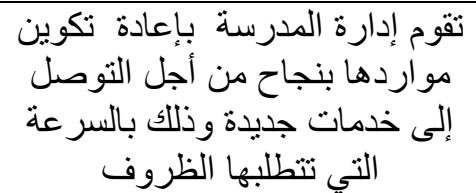 & V \\
\hline$\wedge$ & منخفضة & $1, r T$ & $r, r)$ & $1 \pi$. & تخص موارد إدارة المدرسة ما لتحسين تقديم & $\wedge$ \\
\hline v & منخفضة & $1, r$ & r, YO & T. & 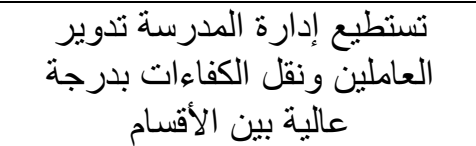 & 9 \\
\hline 9 & منخفضة & $1, r_{1}$ & $r, r)$ & $\pi$. & بإعادة نوزيع الهيكل التنظيمي للمدرسة بئة الأرد بمرونة عالية & 1. \\
\hline 17 & منخفضة & 1,10 & $r, \ldots$ & $1 \pi$. & تحرص إدارة المدرسة علي إبقاء & 11 \\
\hline
\end{tabular}

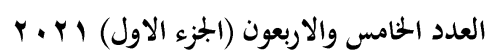

(233)

مجلة كلية التربية- جامعة عين تشس 
تأهيل مديري مدارس التربية الخاصة بححافظة البحر الأحمر في ضوء محددات الرثاقة الإستراتيجية

\begin{tabular}{|c|c|c|c|c|c|c|}
\hline الترتيب & 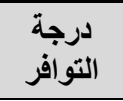 & المعياري & المتسابي & العدد & العبارات & r \\
\hline & & & & & كفاءات وقدرات العاملون فيها علي & \\
\hline $1 \varepsilon$ & منخفضة & $1,1 \mathrm{~V}$ & $r, \cdot 9$ & $1 \%$. & 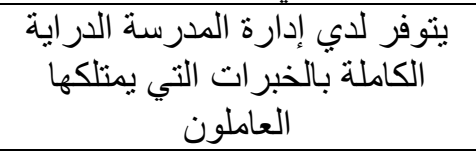 & ir \\
\hline Ir & منخفضة & 1, ro & $r, 10$ & $1 \%$. & 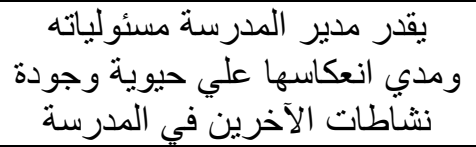 & 14 \\
\hline 1. & منخفضة & $1, r_{1}$ & $r, 19$ & $1 \%$. & يسعي مدير المدرسة إلّي الاحتفاظ & $1 \varepsilon$ \\
\hline 11 & منخفضة & $1, r_{0}$ & $r, 1 \wedge$ & $1 \%$. & تحد الدد البشرة المدرسة بعد دراستبة شامها منة & 10 \\
\hline $1 \pi$ & منخفضة & $1, Y^{\prime}$ & $r, I r$ & $1 \%$. & 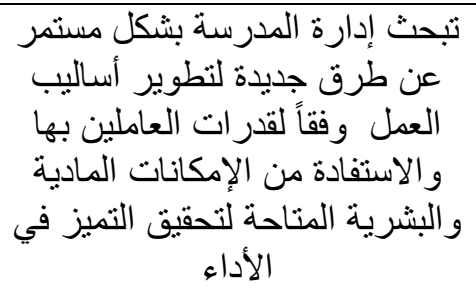 & 17 \\
\hline$r$ & منذفضة & $\cdot, \wedge r$ & $r, \leqslant q$ & 14. & المحدد الثاني : سيولة الموارد & \\
\hline
\end{tabular}
ويظهر من الجدول السابق:

أن العبارة (r) و التي تتص علي " توفر إدارة المدرسة وصولاً سهلاً إلى المعلومات التي تهم عملائها وموظفيها" قد حصلت علي المرتبة الأولي بمتوسط حسابي

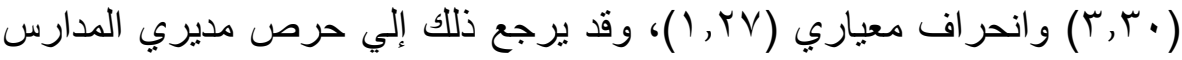
علي إطلاع أفراد المدرسة سواء العاملين و المعلمين و أفراد المجتمع المحلي الذين يتعاملون مع إدارة المدرسة علي المعلومات الكافية التي تشجع علي تقديم مقترحات و أفكار تساهم في تقديم خدمة تعليمية منميزة. كما جاءت العبارة (r) و التي تتص علي " تقوم إدارة المدرسة بإعادة تخصيص الموارد المالية بناءً على منطلبات العمل المتغيرة"في المرتبة الثانية بمنوسط حسابي 


\section{د. رجب أحمد عطا محمد}

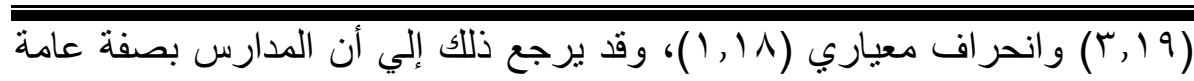
ومدارس لتربية الخاصة بصفة خاصة تعيش اليوم في ظروف متغيرة ومعقدة وشديدة السرعة وتتز ايد داخلها المشكلات الإدارية والتنظيمية الأمر الذي يفرض التغيير و التطوير، و هذا يتطلب إعادة تخصبص الموارد المالية بناء علي متطلبات

العمل المتغيرة. كما جاءت العبارة ( V) والتي تتص علي" تقوم إدارة المدرسة بإعادة تكوين مواردها بنجاح من أجل التوصل إلى خدمات جديدة وذلك بالسرعة التي تتطلبها الظروف" في المرتبة قبل الأخيرة بمتوسط حسابي (Y, · (Y) وبانحراف معياري (9 ( 1 (1)، وقد يرجع ذلك إلي نتيجة اهتمام محدود من قبل مديري المدارس بأهمية تطبيق أساليب موضوعية قي عملية اختيار الموارد البشرية وعدم الاهتمام بمتابعة استقطاب الكفاءات المتميزة، كما لا يوجد تتقييم فعال لاحتياجات المدارس من الموارد البشرية و المادية حسب الظروف المتغيرة الداخلية و الخارجية. كما جاءت العبارة (11) والتي تتص علي "تحرص إدارة المدرسة علي إبقاء كفاءات وقدرات العاملون فيها علي أعلي مستوياتها" في المرتبة الأخيرة بمتوسط

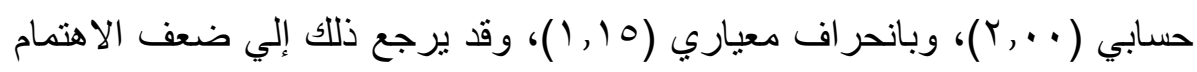
من قبل مديري المدارس بوضع استراتيجية واضحة لتقييم أداء الموارد البشرية للوقوف علي قدرات وكفاءات العاملين وطرق تفعيل هذه القدرات والكفاءات للوصول إلي أعلي مستوي وجودة من الأداء في ضوء متطلبات القرن الحادي و العشرين. وخلاصة ماسبق، يتضح أن العبارات المتعلقة بالمحدد الثاني" سيولة الموارد" من محددات الرشاقة الاستراتيجية علي النحو المجمل في المدي الضعيف بمتوسط حسابي

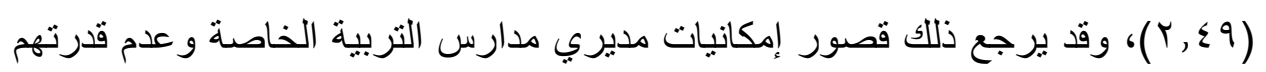
علي إعادة تخصيص الموارد الرأسمالية المادية والبثرية والاستخدام الأمثل لها 
تأهيل مديري مدارس التربية الخاصة بمحافظة البحر الأحمر في ضوء محددات الرشاقة الإستراتيجية


و إعادة تأهيلها في ضو و المتغير ات العلمية و المحلية . ج- نتائج خاصة بالبعد الثالث ( وحدة القيادة) يوضح الجدول رقم ( • () المتوسطات الحسابية والانحرفات المعيارية ودرجة التو افر لاستجابات العينة ككل علي العبار ات في البعد الثالث الخاص بوحدة القيادة.

\begin{tabular}{|c|c|c|c|c|c|c|}
\hline الترتيب & التوافر & الالحعراف & المتوسط الحسبي & العدد & العبارات & م \\
\hline 7 & متوسطة & سז, & $r, V T$ & . & 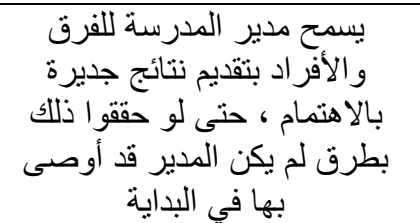 & 1 \\
\hline r & متوسطة & 1,10 & $r, \cdot v$ & r. & 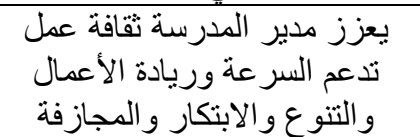 & r \\
\hline 1 & متوسطة & ס & $r, 11$ & ש & لإجراء التغيير ات المدرسة مستعد دائمًا & r \\
\hline r & متوسطة & $1, \mathrm{r}$ & $r, \cdot \Lambda$ & ש & 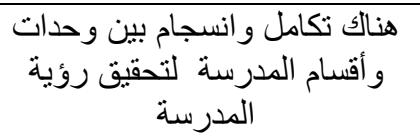 & $\varepsilon$ \\
\hline 0 & متوسطة & $1, \pi$. & $r, \cdot 1$ & . & تركز إدارة المدرسة على تشجيع & 0 \\
\hline$\varepsilon$ & متوسطة & $1, r Y$ & $r, \cdot T$ & r. & طرق العقاب و المكافأة و اضحة & 7 \\
\hline $1 \leqslant$ & منخفضة & 1,19 & $r, \cdot \Lambda$ & . & يعمل جميع الموظفين بروح & V \\
\hline$\wedge$ & منخفضة & T & $r, Y_{1}$ & $1 \pi$. & الششتركة إدارة المدرسة الأطر افؤولية التي & $\wedge$ \\
\hline V & منخفضة & $1, r$. & Y, YO & r. & العاملين فرصة مدير اللتعلم وتحة أخطاء & 9 \\
\hline Tr & منخفضة & $1, r_{0}$ & $r, . q$ & . & أصحاب المصلحة إدارة المدرسة جميع فيع فئية & 1. \\
\hline
\end{tabular}

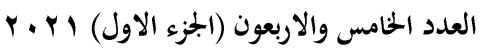


د. رجب أحمد عطا محمد

\begin{tabular}{|c|c|c|c|c|c|c|}
\hline الترتيب & التوافة & الانحراف المعياري & المتوسط المسي & العدد العد & العبارات & r \\
\hline 10 & منخفضة & 1,17 & $r, \cdot r$ & $1 \pi$. & 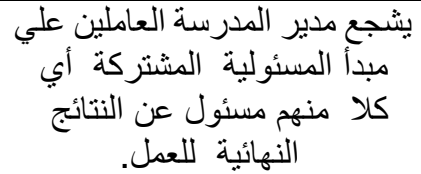 & 11 \\
\hline 11 & منخفضة & 1,10 & $r, I T$ & $1 \pi$. & تتحمل فرق العمل المسئولية & Ir \\
\hline 9 & منخفضة & $1, Y_{1}$ & $r, 19$ & Ir. & 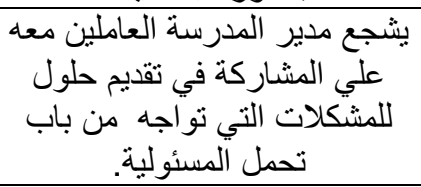 & r \\
\hline 1 . & منخفضة & $1, r_{0}$ & $r, 1 \wedge$ & $1 \%$. & العاملين علي المشاليب المدركة في جميع تحسين & $1 \leq$ \\
\hline ir & منخفضة & $1, Y 7$ & $r, I r$ & $1 \pi$. & لدي مدير درجة عالية من الثقة & 10 \\
\hline$r$ & منخفضة & $\cdot, \Lambda r$ & $r, 0$. & $1 \%$. & المحدد الثالث: وحدة القيادة & \\
\hline
\end{tabular}

\section{ويظهر من الجدول السابق:}

أن العبارة (r) و التي تنص علي" مدير المدرسة مستعد دائمًا لإجراء التغييرات اللازمة عند الحاجة إلى التغيير" قد حصلت علي المرتبة الأولي بمتوسط حسابي (1, (1)

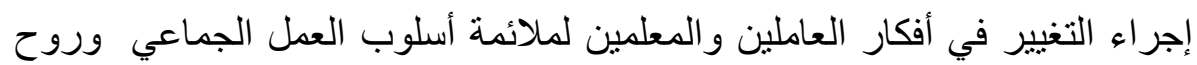
الفريق في أداء رسالة ورؤية المدرسة علي أرض الو اقع. كما جاءت العبارة (ع) و التي تنص علي" هناك تكامل و انسجام بين وحدات و أقسام المدرسة لتحقيق رؤية المدرسة" في المرتبة الثانية بمتوسط حسابي (^ی, (؟) وانحراف معياري (1), (1)،وقد يرجع ذلك إلي طبعية العمل في مدارس التربية الخاصة التي تحرص علي تبادل الارشاد والنصح بين العاملين في مجال التربية

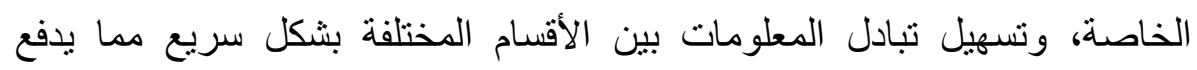
مديري المدارس إلي الحرص دائما علي تحفيز كل وحدات و أقسام المدرس لتقديم 
تأهيل مديني مدارس التربية الخاصة بحافظة البحر الأحمر في ضوء محددات الرشاقة الإستراتيجية

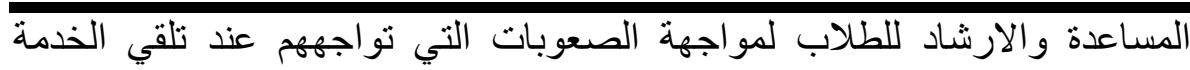
التعليمية مما يسهل تحقيق رؤية المدرسة بطريقة سهلة ومرنة. كما جاءت العبارة (V) و التي تتص علي " يعمل جميع الموظفين بروح الفريق

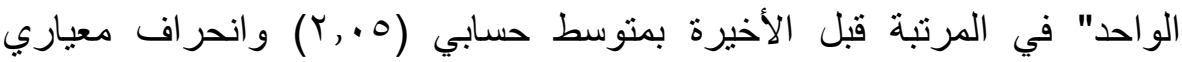
(1, (1, (1)، مما يثير إلي إخفاق مديري المدارس في القدرة علي تبادل الخبرات

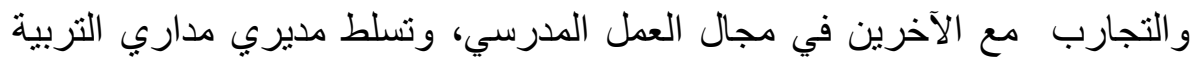
الخاصة وانفر ادهم بسلطة اتخاذ القرارات دون الاهتمام بإثر الك العاملين والمعلمين في تلك العملية. كما جاءت العبارة (1') و التي تتص علي" بثجع مدير المدرسة العاملين علي مبدأ

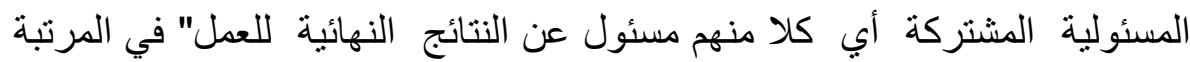

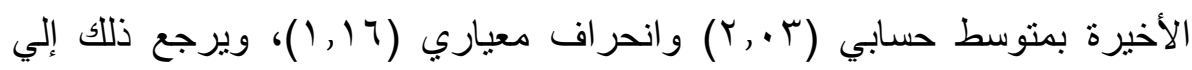
ضعف النقة من قبل مديري مدارس التربية الخاصة في العاملين و المعلمين لإدر اكهم ضعف مسايرة المعلمين والعاملين لتطورات الحادثة في مجال التربية الخاصة و الاتجاهات التربوية المعاصرة في مجال تعليم ذوي الاحتياجات الخاصة، وإدراك مديري الددارس ضعف فعالية برامج التنمية المهنية للمعلمين والعاملين في مدارس التربية الخاصة وشكليتها، وتركيز ها علي الجوانب النظرية دون الجوانب التطبيقية .

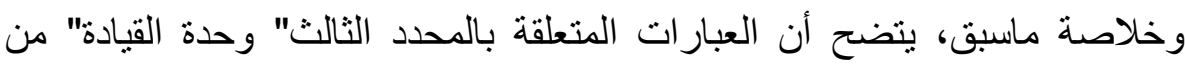
محددات الرشاقة الاستر اتيجية علي النحو المجمل في الددي الضعيف بمتوسط حسابي

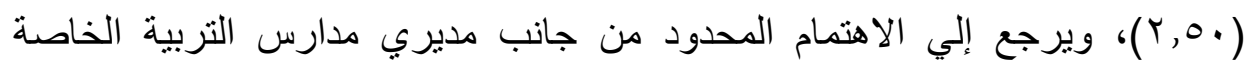
بإنشراك العاملين و المعلمين في القرارات والخطط المدرسية، وتوفير موظفين مؤهلين

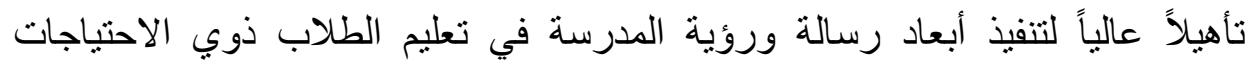

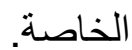


د. رجب أحمد عطا محمد

د- نتائج خاصة بالبعد الرابع ( التكنولوجيا)

يوضح الجدول رقم (1 (1) المتوسطات الحسابية والانحرفات المعيارية ودرجة التو افر

لاستجابات العينة ككل علي العبار ات في البعد الر ابع الخاص بالتكنولوجيا.

\begin{tabular}{|c|c|c|c|c|c|c|}
\hline الترتيب & 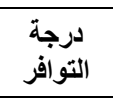 & الانحراف & المتوسط الحسبي & العدد & العبارات & p \\
\hline 7 & متوسطة & $1, r q$ & $r, \Lambda r$ & $1 T$. & 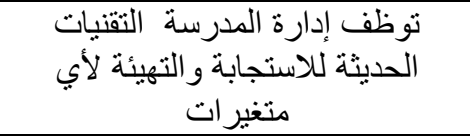 & 1 \\
\hline$r$ & متوسطة & 1,17 & $r, \cdot v$ & $1 \pi$. & 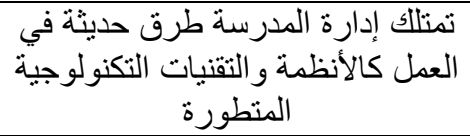 & $r$ \\
\hline 1 & متوسطة & $1, r_{0}$ & $r, r \wedge$ & $1 \pi$. & 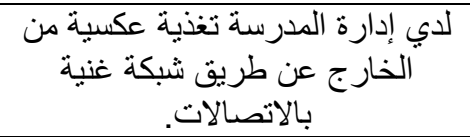 & $r$ \\
\hline$r$ & متوسطة & $1, \pi$ & $r, \wedge$ & . & للمعلومات الإدارة المدرسة مرتبط نظام فعالإدارة & $\varepsilon$ \\
\hline 0 & متوسطة & $1, r$. & $r, \cdot 1$ & IT. & 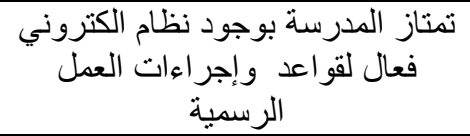 & 0 \\
\hline$\varepsilon$ & متوسطة & $1, K r$ & $r, \cdot \tau$ & $1 \pi$. & من مو اجهة البني التحتية لتقنية المعلومات للتنافس السريع & 7 \\
\hline IV & منخفضة & 1,19 & $r, \wedge$ & . & 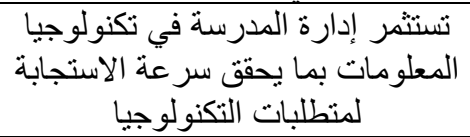 & $V$ \\
\hline 9 & منخفضة & 1, & $r, Y_{1}$ & . & آخر التطور إدات التكنولوجية فلى في البيئة المبة & $\wedge$ \\
\hline V & منخفضة & $1, Y$. & r, YO & . & تسهم التكنولوجيا المستخدمة بالمدرسة إنجاز سرعة & 9 \\
\hline 1. & منخفضة & $1, Y_{1}$ & $r, Y)$ & . & 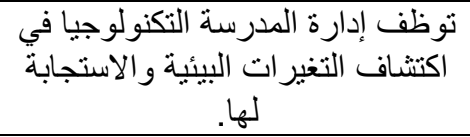 & 1. \\
\hline 10 & منخفضة & 1,10 & $r, \wedge$ & $1 T$. & 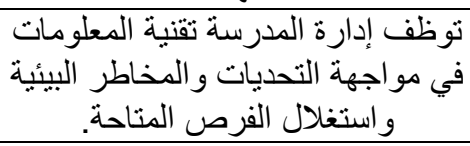 & 11 \\
\hline 11 & منخفضة & 1,17 & $r, .9$ & $1 \%$ & لدي إدارة المدرسة القدرة علي تحديد & ir \\
\hline
\end{tabular}

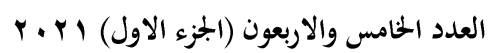

(239)

مجلة كلية التربية- جامعة عين شمس 
تأهيل مديزي مدارس التربية الخاصة بمحافظة البحر الأحمر في ضوء محددات الرشاقة الإستراتيجية

\begin{tabular}{|c|c|c|c|c|c|c|}
\hline الترتيب & 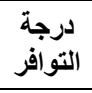 & المعياري & المسابي & العدد & العبارات & p \\
\hline & & & & & 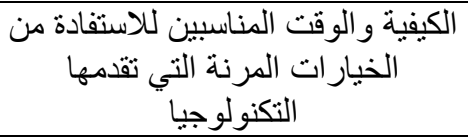 & \\
\hline 11 & منخفضة & 1,19 & $r, \cdot \Lambda$ & $1 \%$. & 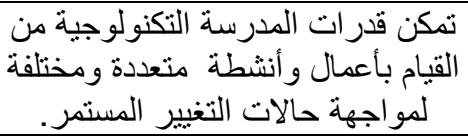 & $1 \pi$ \\
\hline 11 & منذفضة & $1, r$ & $r, r)$ & 14. & توفر المدرسة قاعدة بيانات الكترونية & $1 \leq$ \\
\hline$\Lambda$ & منخفضة & $1, r$. & $r, r_{0}$ & $1 \pi$. & 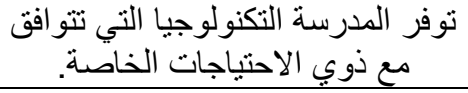 & 10 \\
\hline Kr & منخفضة & $1, Y)$ & $r, r)$ & $1 \%$. & 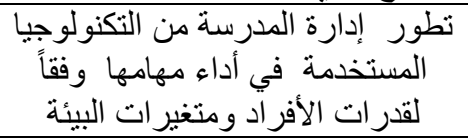 & 17 \\
\hline 17 & منخفضة & 1,10 & $r, \cdot \wedge$ & 14. & 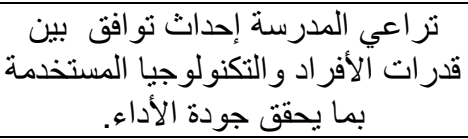 & iv \\
\hline $1 \varepsilon$ & 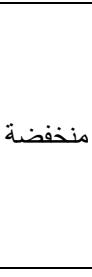 & 1,17 & $r, .9$ & $1 \pi$. & 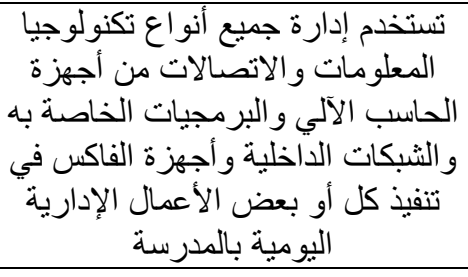 & 11 \\
\hline$\varepsilon$ & منخفضة & $\cdot, \lambda$ & $r, \leqslant 4$ & ir. & المحور الرابع : التكنولوجيا & \\
\hline
\end{tabular}

$$
\text { ويظهر من الجدول السابق : }
$$

أن العبارة (r) و التي تنص علي" لدي إدارة المدرسة تغذية عكسية من الخارج عن طريق شبكة غنية بالاتصالات" جاءت في المرتبة الأولي بمنوسط حسابي (؟,Y و انحراف معياري (1, 1, وقد يرجع ذلك إلي اهتمام مديري مدارس التربية الخاصة بمعرفة مدي رضا المجتمع المحلي وأولياء امور الطلاب عن الخدمةالتعليمية المقدمة من خلال أعضاء المدرسة سواء المعلمين و العاملين. كما جاءت العبارة (ع) و التي تتص علي" لدي إدارة المدرسة نظام فعال للمعلومات الإدارية مرتبط بالإدارة العليا من خلال شبكة داخلية" في المرتبة الثانية بمتوسط 
د. رجب أحمد عطا محمد

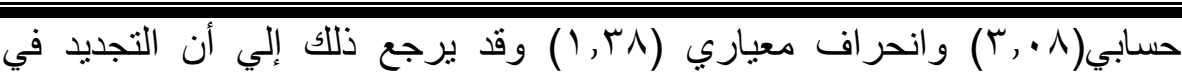
المدارس يتمثل في أن تعليم التلاميذ وتأهيلهم يكون باستخدام التكنولوجيا الحديثة، لأن توظيف التكنولوجيا في التعليم والتعلم وتفعيل دور شبكات التو اصل الاجتماعي في التعليم والتعلم قد يسهم في تطوير مخرجات التعليم المدرسي بما ينسجم مع التطورات المتسارعة التي تشهدها القرن الحالي، مما يؤدي إلي اهتمام مديري المدارس بتوفير نظام فعال للمعلومات الإدارية مرتبط بالموجهين والمشرفين في الإدار ات العليا بشكبة معلومات تكنولوجية داخلية كما جاءت العبارة (V) والتي تتص علي" تستثمر إدارة المدرسة في تكنولوجيا المعلومات بما يحقق سرعة الاستجابة لمتطلبات التكنولوجيا " في المرتبة قبل

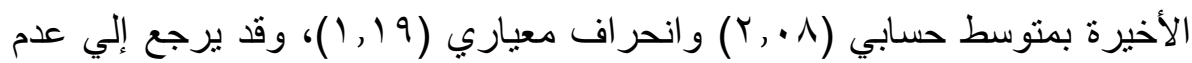
إدراك مديري مدارس التربية الخاصة أن من خلال تكنولوجيا المعلومات تسنطيع المدارس توفير نظام عمل فعال موثث يمكن الرجوع إليه لتحديد الاعمال و الوظائف وتتمية قدرات العاملين والمعلمين و التلاميذ للاستجابة الفعالة والسريعة للمتغيرات وثورة المعلومات و التكنولوجيا. كما جاءت العبارة (r ا ) و التي تتص علي" تمكن قدرات المدرسة التكنولوجية من القيام بأعمال و أنشطة متعددة ومختلفة لمواجهة حالات التغيير المستمر" في المرتبة

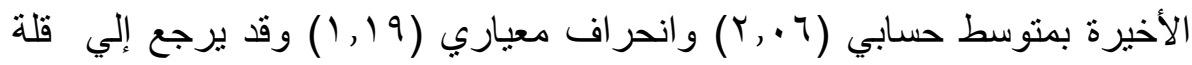
الإمكانات المادية والأجهزة اللازمة لعملية التعلم، والقصور الواضح في تجهيز حجرات للمصادر التعليمية، والاستخدام الضعيف للتكنولوجيا، وعدم وجود قاعدة بيانات عن الإعاقات و الوسائل التعليمية التكنولوجية الملائمة لكل إعاقة . وخلاصة ماسبق، يتضح أن العبارات المتعلقة بالمحدد الرابع" التكنولوجيا" من محددات الرشاقة الاستراتيجية علي النحو المجمل في المدي الضعيف بمتوسط حسابي

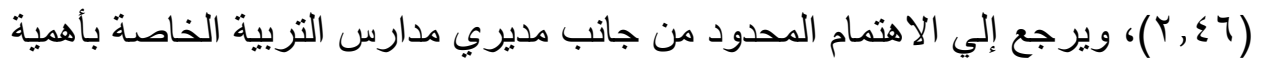


تأهيل مديزي مدارس التربية الخاصة بححافظة البحر الأحمر في ضوء محدات الرشاقة الإستراتيجية

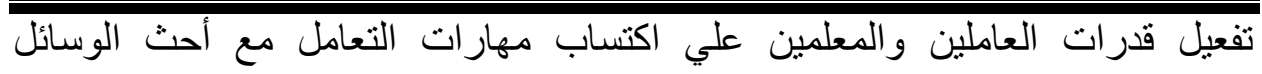

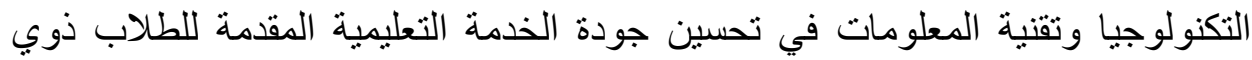

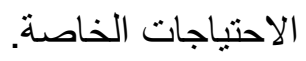

خامساً: مبررات ودواعي تأهيل مديري مدارس التربية الخاصة من خلال التعرف علي واقع مدارس التربية الخاصة في ضوء محددات الرشاقة الاستراتيجية يتضح أن من المهم التفكير فيما إذا كانت البيئة الددرسية تساهم في التغلب التبان علي الصعوبات التي قد يواجهها الدتعلم في مدارس التربية الخاصة، يجب أن تكون الدارس حساسة وتدرك أن تتمية الأطفال تتضمن "الاستعداد للتعلم" و "الاستعداد للمدرسة". "الاستعداد للتعلم" يعني أن لديهم التطور المعرفي اللازم لتعلم مفاهيم وأفكار محددة، و"الاستعداد للمدرسة" يتضمن مجموعة محددة من المهارات المعرفية واللغوية والاجتماعية والحركية التي تمكن الطفل من استيعاب المناهج المدرسية، ويعني الاهتمام

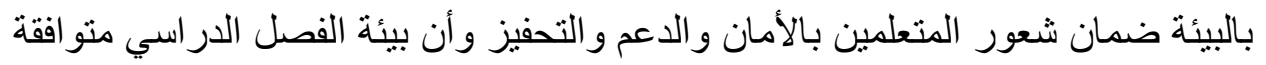
مع التعلم الفردي و الاحتياجات الاجتماعية والمادية للمتعلمين. ولتحقيق هذا مطلوب: - مدير مدرسة ذات قدرات متميزة تتصف بالرشاقة والحساسية الاستر اتيجية و التوظيف الفعال للتكنولو جيا المساعدة لعملية التعلم .

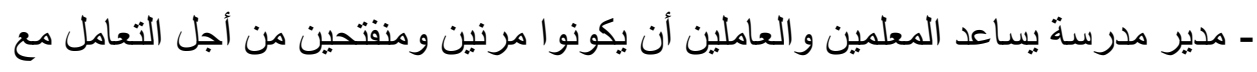
أطفال لديهم نقاط قوة وتحديات واهتمامات مختلفة ولا يمكن تلبية الاحتياجات المتعددة والمعقدة بنموذج أو صيغة واحدة. بستغرق الأمر وقتًا طويلاً وتفكيرًا إبداعيًا وتعاونًا وتمويلًا مناسبًا وإمكانية الوصول و البحث وتدريب المعلمين على أساس مستمر. - مدير مدرسة ينفة سياسة تحدد بوضوح الخدمات و الدعم والموظفين المتاحين للأطفال ذوي الاحتياجات التعليمية الخاصة وجعل هذه المعلومات في متتاول أولياء الأمور. - مدير بثجع العمل بشكل جماعي كفريق (معلمين ، عاملين في مجال الرعاية الصحية أخصائيين اجتماعيين، إلخ) لتقليم رعاية شاملة للطفل ذي الاحتياجات التعليمية الخاصة. 
د. رجب أحمد عطا محمد

- مدير يهتم بشكل دائم بتوفير فرص التدريب المتعلقة بالتطوير المهني المستمر لجميع المعلمين في الفصول الدراسية، ورش العمل والتعلم عبر الإنترنت و المؤتمرات لتلبية الحاجة إلي تحسين أداء المعلمين. حيث بلعب المعلمون دورًا أساسيًا في توفير تجربة تعليمية إيجابية ومجزية لجميع الأطفال.

- مدير يهتم بمعرفة آراء و أفكار المعلمين، ولديه القدرة علي دمج آرائهم ومعرفتهم حول كل من المناهج وطلابهم كمتعلمين قبل تخطيط التعليم والتقييم. ويعد التوافق الجيد أمرًا ضروريًا بين هذين المكونين الأساسيين من أجل توفير فرص تعلم مناسبة وفعالة لجميع الطلاب.

- - مدير يستطيع تزويد المتعلمين بالهياكل اللازمة لتعظيم نقاط قوتهم، ومعالجة نقاط ضعفهم، وتجربة العلاج في الوقت المناسب. يمكن هذا الطلاب من استخدام استر اتيجيات التعلم الفعالة و المشاركة في تعلمهم. نتيجة لذلك، يزداد تحفيز الطلاب ويظل الطلاب مهتمين بالتعلم. - مدير مدرسة يمتلك رؤية مستقبلية لتطوير المدرسة ونوفير مناخ إيجابي ويتطلب ذلك ما يلي: الفدرة علي التخطيط و إعداد الخطط الاستراتيجية للمدرسة، والإلمام بكافة القو انين و اللوائح و النشرات المنظمة لإدارة المدرسة، وتوفير بيئة آمنة وحامية لكافة الطلاب و العاملين دون تمبيز بينهم. - مدير مدرسة لديها القدرة علي توفير بيئة مدرسية يسودها بعض القيم مثل: التعاون الايجابي، الاحترام المتبادل، و العدالة، والمساواة، واحترام التنوع لكافة الطلاب و العاملين بما يسهم في توفير مناخ إيجابي جاذب للطلاب و العاملين. - مدير مدرسة لديه القدرة علي توظيف تكنولوجيا التعليم داخل مدارس التربية الخاصة كمتطلب ضرورياً يساعد علي أن يكون التعلم بصورة أفضل لقيمته العظيمة بالنسبة للأطفال المعاقين إذ يجعل التعلم مسلياً ومثيراً ويبعد عنه الملل. 
تأهيل مديري مدارس التزبية الخاصة بحافظة البحر الأحمر في ضوء محددات الرشاقة الإستراتيجية وتفرض هذه التحديات علي المسئولين عن إدارة مؤسسات التربية الخاصة فئل ضرورة تأهيل مديري مدارس التربية الخاصة لاكتساب أفضل لمهارات الحساسية الاستر اتيجية للارتقاء بجودة التعليم في مدارس التربية الخاصة بغية تحقيق أفضل النتائج وفقاً للأهداف التربوية المحددة لمسايرة المتغيرات العالمية ومحاولة التكيف معها. سادساً: التصور المقترح لتأهيل مديري مدارس التربية الخاصة بالبحر الأحمر في ضوء محددات الرشاقة الاستراتيجية: انطلاقاً من الإطار النظري للبحث والذي تضمن عرضاً تحليلياً للرشاقة الاستر اتيجية ومفهومها و أهميتها ومحدداتها، ومتطلبات ودو اعي تطبيقها في المؤسسات التعليمية، والتعرف علي مدي ممارسة مديري مدارس التربية الخاصة بالبحر الأحمر

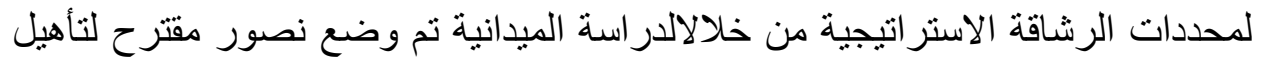
مديري مدارس التربية الخاصة في ضوء محددات الرشاقة الاستر اتيجية. (أ) منطلقات التصور المقترح :

ينطلق النصور المقترح من مجمو عة من الدنطلقات التي تتمثل فيما يلي :

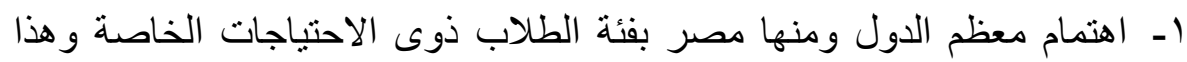

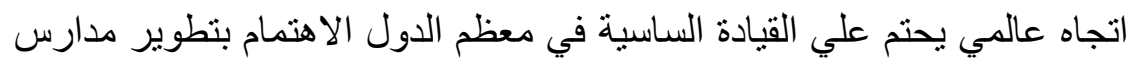

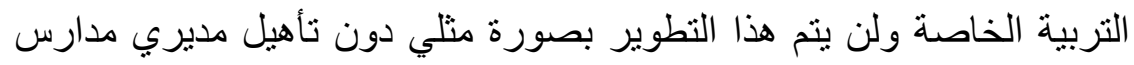

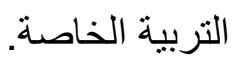
r- يساهم ممارسة محددات الرشاقة الاستراتيجية في تحسين قدرات وكفاءات

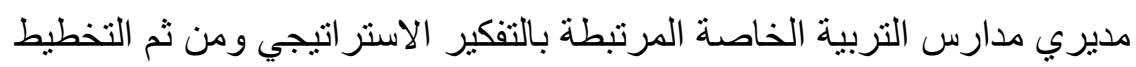
بطريقة استراتيجية واضحة الأهداف و الاجراءات.

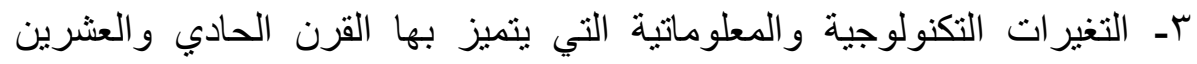
والتي تفرض علي مدارس التربية الخاصة وقادتها حسن نوظيف هذه 
د. رجب أحمد عطا محمد

المتغيرات برشاقة ويقظة لرفع جودة وكفاءة الخدمة التعليمية و العاملين علي

تقديمها.

ع- تطبيق الرشاقة الاستر اتيجية بمدارس التربية الخاصة من أهم العوامل التي تؤثر في تحقيق النجاح الاستراتيجي بأبعاده التنفيذ الفعال للاستراتيجية والثقاقة

التحفيزية للعاملين و المعلمين ورضنا العملاء.

(ب) أهداف التصور المقترح:

يسعي هذا التصور إلي تحقيق الأهداف الآتية:

ا - تحسين أداء مديري مدارس التربية الخاصة من خلال الرشاقة والمرونة في التعامل مع المتغيرات المحلية والعالمية وبما يتوافق مع رؤية الدولة والاهتمام الو اضح بذوي الاحتياجات الخاصة من الطلاب ومساعدتهم علي التعلم. r- تأهيل مديري مدارس التربية الخاصة بوضع بر امج تدريبية للتنمية المهنية تدعم

$$
\text { التقكير الاستر اتيجي و الابتكار والابداع. }
$$

ب- تطوير أساليب العمل داخل مدارس التربية الخاصة فيما بتعلق بصنع واتخاذ

$$
\text { القرار ات التعليمية. }
$$

(ج) أبعاد التصور المقترح:

$$
\text { من أهم أبعاد التصور المقترح ما يلي: }
$$

ا - الرشاقة الاستر اتيجية والتجديد: كل جديد أو تغير في الأفكار والسياسات و الاستر اتيجيات اللازمة لتنفيذ أهداف العملية التعليمبة بؤدي إلي تغبير ات مملوسة في مخرجات التعليم وتتسم بالإبداع، أي استخدام المعارف الجديدة لتعزيز السلوك الإبداعي لاكتشاف الفرص الجديدة، ويمثل الابتكار والإبداع أحد المتطلبات الأساسية في الإدارة المعاصرة، إذ لم بعد كافياً أو حتى مرضياً اداء الأعمال في المدارس على اختلاف انواعها بالطرائق الروتينية التقلبدية لأن الاستمرار بها قد يؤدي إلى فثل الإدارة ، من أجل ضمان بقائها واستمرار ها ، يجب أن لا تقف عند حد الكفاءة 
تأهيل مديري مدارس التزبية الخاصة بحافظة البحر الأحمر في ضوء محددات الرشاقة الإستراتيجية

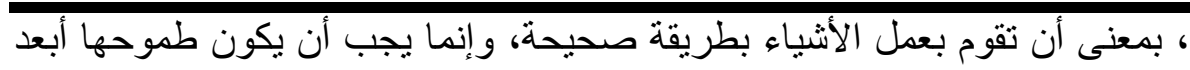

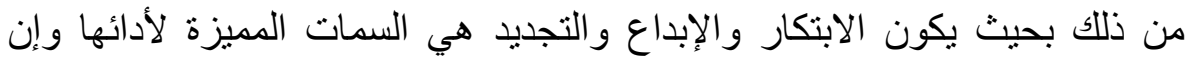
الإدارة المعاصرة والحديثة تحتاج إلى تعديل في نمط اتخاذ القرار، وتحسين وتطوير

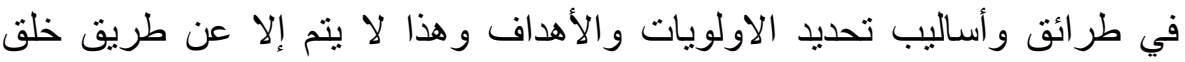
و إيجاد المناخ التنظيمي الملائم والمناسب الذي يتيح ويفسح المجال للفكر الابتكاري و الإبداعي في الظهور، ويتطلب النجاح اليوم الرشاقة والدافع لإعادة التفكير

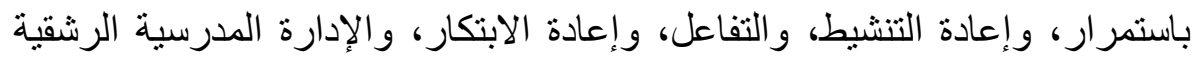
تعمل دائما علي حثد قدرات المدرسة وجهودها ومواردها و التنسيق بينها للوصول

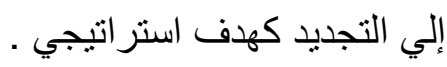
r- الرشاقة الاستراتيجية والتميز التنظيمي: هو تميز اداري ووظيفي يتأتى من خلال الاستثمار في الامكانات غير المستغلة في العاملين ويتسم بنقاط قوة تنمثل في تميز القادة المرؤوسين ، وتميز الهيكل التنظيمي، وتميز الثقافة التنظيمية ، أي علي إدارة الدرسة تركيز جهودها وطاقاتها علي تحسين وتجويد الدخلات والعمليات والمخرجات الددرسية ، ومن اجل تحقيق ذلك تعمل الرشاقة الاستراتيجية علي

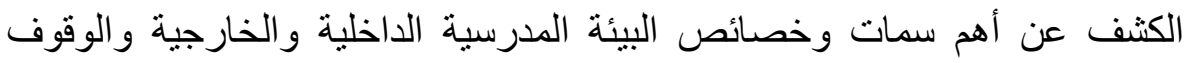
علي نقاط القوة و الضعف و الفرص و التهديدات،وحصر البدائل و الخيارات الاستراتيجية لتحقيق جودة الموارد الددرسية البشرية والمادية كهدف استراتيجي تسنطيع الددرسة من خلالها الوصول إلي التميز.

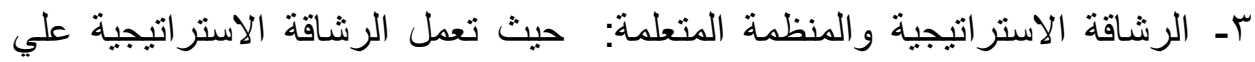



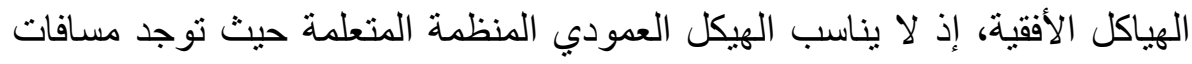

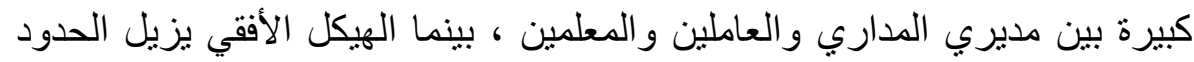
بين أعضاء المدرسة ويعتمد علي فرق العمل لاتخاذ القرار، والتحول من من الثقافة 
د. رجب أحمد عطا محمد

المتصلبة متصلبة إلي الثقافة المتكيفة حيث تقتضي ضرورة التغيير التنظيمي أن لا تكون التقافة التنظيمية متصلبة قاسية إذ لا يمكن للمنظمة معها التكيف مع البيئة المحبطة والاستجابة للتغيير، لكن المدرسة كمنظمة متعلمة تشجع علي الانفتاح و إز الة الحدود و الجودة والتحسين المستمر، والاستخدام الأمثل للموارد، عن طريق تبادل الخبرات بصورة جماعية. ـ - الرشاقة الاستر اتيجية والاستجابة لحاجات العميل:الإدارة المدرسية الرشيقة من خلالها حساسيتها العالية للبيئة المحيطة تكون قادرة علي معرفة احتياجات المجتمع المحلي وطلابها وخاصة في مدارس التربية الخاصة، وتقوم بتقييم احتياجات العملاء بشكل منهجي، وقدرة المدرسة علي البقاء علي قيد الحياة تعتمد علي تعزيز قدر اتها وكفاءاتها الأساسية لتصبح رائدة في مجالهامع تحديد احتياجات العملاء ورغباتهم و التفكير في طرق جديدة للقيام بالأعمال . 0ـ الرشاقة الاستراتيجية والأداء الاستر اتيجي: حيث تعمل الرشاقة الاستر اتيجية علي زيادة قدرة المنظمة علي أن تربط حاضرها بمستقبلها ومدى استجابتها لمو اردها المادية والبشرية واستغلالها بالصورة التي تجعلها قادرة علي تحقيق أهدافها من خلال تحسين أبعاد الأداء الاستراتيجي المتمثلة في: سرعة الاستجابة في تلبية احتياجات العميل دون تأخير في الوقت مما يعكس رضا العميل عن أداء المدرسة، والابداعات المستمرة في توليد أفكار جديدة لجميع العناصر الموجودة من أجل استحداث مصادر جديدة ذات قيمة، والتعلم الاستراتيجي من خلال وجود رؤية مشتركة موحدة بين أعضاء المدرسة نحة مستقبل المدرسة وأهدافها مما يزود قادة المدرسة والمعلمين و العاملين بالطاقة اللازمة للتعلم والتصرف بما يتفق مع أهداف مودة المدرسة وتوجهاتها المستقبلية ، وتوقع التغير في البيئة المدرسية الداخلية والخارجية والاستعداد لها بوضع خطط واستر اتيجيات للتوافق معها و التخفيف من حدة أثرها و الضغوظ المصاحبة لها. 
تأهيل مديري مدارس التربية الذاصة بححافظة البحر الأحمر في ضوء محددات الرشاقة الإستراتيجية

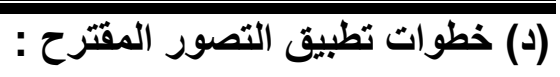

يتم تطبيق أبعاد هذا التصور المقترح لتأهيل مدبري مدارس التربية الخاصة

بالبحر الأحمر في ضوء محددات الرشاقة الاستر اتيجية وفقا للخطوات التالية:

ا - اقتناع قيادات التعليم سواء في وزارة التربية والتعليم والمديريات والادارات

التعليمية علي مستوى المحافظة باهمية دور مديري مدارس التربية الخاصة في تحقيق التجديد و الجودة و الأداء الاستر اتيجي، وجعل تأهيل مديري المدارس للتكيف مع التطور والتغير ضمن أولوياتهم عن وضع الخطط والسياسات التعليمية التجديدية.

r- التتخيص الدوري لواقع ممارسة مديري مدارس التربية الخاصة للكفايات الفنية، وتحديد الاحتياجات الفعلية لكل قائد مدرسي من الكفايات، واستخدام الأساليب العلمية المتقدمة والمتنو عة لهذا الغرض. r- إعادة النظر في شوط ومعايير اختيار قادة المدارس وتضمين محددات الرشاقة الاستراتيجية في شروط ومعايير اختيار مديري المدارس ، و إعداد قوائم تتضمن محددات الرشاقة الاستراتيجية مثل الحساسية الاستراتيجية وسيولة الموارد ووحدة القيادة والتكنولوجيا وطرق قياسها لدي مديري المدارس لتطبيقها علي من يقدم لمنصب مدير مدرسة. عـ تشكيل عدد من المراكز التدريبية علي مستوي المدن والمحافظات وعلي مستوي الدولة تقدم برامج تدريبية وتأهلية متطورة لمديري مدارس التربية الخاصة، وتتكون هذه اللجنة من الباحثين وأساتذة الجامعة في تخصصات لتصات الإدارة التربوية و علم النفس التربوي وبعض المسئولين في الأكاديمية المهنية للمعلمين، وتختص وله بوضع برنامج تدرييي بهدف تأهليهم لمسايرة التغير ات الحالية التي يشهدها العالم و التي تقتضي الاهتمام بالجانب التربوي و إصلاحه.

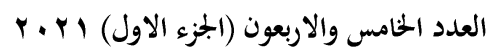

(248)

جلة كلية التربية- جامعة عين شمس 
د. رجب أحمد عطا محمد

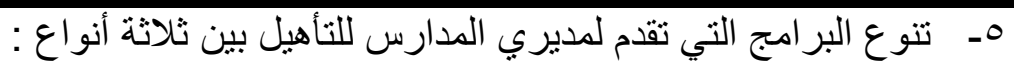

- برنامج تأهيلي لمديري المدارس الجدد وهذا البرنامج يمد مديري المدارس الجدد بأهم المعلومات و المهارات اللازمة لهم، وبعد اجتياز هذا البرنامج بنجاح يحصل مدير المدرسة علي شهادة تأهيلية لنغل منصب مدير مدرسة. - برنامج تحسيني يهدف إلي تقديم بر امج تأهيلية تحسن من مستوي مديري المدارس مداء الذين اجتازوا البرنامج التأهيلي . - - برنامج نطويري علي درجة عالية من الكفاءة حيث يتم اختبار مجموعة من مديري

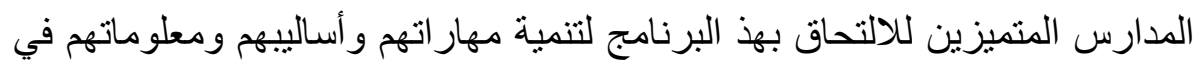

مجال الإدارة المدرسية

؟- ت تنوع محتوي البرامج التدريبية والتأهيلية بين:

- منهج يضم مقررات مثل فلسفة التربية ، الإدارة التربوية الفعالة، الإدارة الالكترونية وتقنية المعلومات

- منهج يرتبط بالتجربة الميدانية لمديري مدارس التربية الخاصة حيث يتم استدعاء بعض مديري مدارس التربية الخاصة المتميزين لتقديم خبراتهم وتجاربهم الميدانية

$$
\text { في مجال الإدارة المدرسية. }
$$

- - تركيز بر امج التأهيل المهني لمديري مدارس التربية الخاصة علي تطوير الكفايات الفنية لمديري المدارس التي تساعدهم عليممارسة محددات الرشاقة الاستراتيجية و التي أظهرت نتائج الدراسة الميدانية أن و اقع ممارستها جاءت بدرجة ضعيفة - معلومات عن القوانين و السياسات التي تؤثر علي حياة الطلاب ذوي الاحتياجات الخاصة وأسر هم. - معلومات عن الظروف الاقتصادية والاجتماعية التي تؤثر علي عملية صنع السياسات التعليمية في مجال التربية الخاصة. 
تأهيل مديري مدارس التربية الخاصة بمحافظة البحر الأحمر في ضوء محدات الرشاقة الإستراتيجية

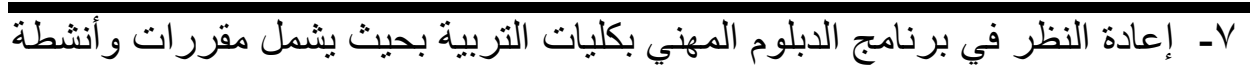

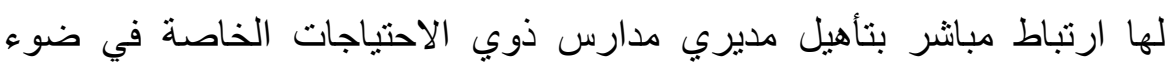
محدات الرشاقة الاستر اتيجية A- تفعيل دور الأكاديمية المهنية للمعلمين في تأهيل مديري مدارس التربية الخاصة من خلال تشكيل فرق تخطيط للتنمية المهنية علي مستوي مديرية التربية والتعليم في المحافظة ير أسها رئيس الأكاديمية، وينبثق عنها لجان متخصصة تكون مهمتها تحديد الاحتياجات التدرييية اللازمة لمديري المدارس لمواكبة التجديدات والمتغيرات المتسارعة ونقلها إلي فرق التخطيط لوضع برنامج تأهيل مناسب لتطوير قدرات ومواهب مديري مدارس التربية الخاصة في ضوء محددات الرشاقة الاستر اتيجية و الأداء الاستر اتيجي. 9- استحداث وحدة خاصة بالاستشعار في الهيكل التنظيمي للأكاديمية المهنية للمعلمين في كل محافظة تختص برصد كل التغيرات الحاصلة في البيئة المحيطة بالمدارس ومن ثم وضع تصور بمحتوي البرامج التدريية والقدرات والمواهب التي يجب تطوير ها لتأهيل مديري المدارس وخاصة التربية الخاصة وتدريبيهم علي وسائل وأساليب الرصد والانتباه إلي الأحداث التي تجري في البيئة الخارجية و الاستفادة منها في إدارة العملية التعليمية. • 1 - عقد شر اكة بين مديريات التربية والتعليم و الأكاديمية المهنية للمعلمين للتعاون

في مجال تأهيل مديري المدارس و القيادات التعليمية. (0) معوقات تطبيق التصور المقترح وسبل التظلب عليها: يتوقع عند تنفيذ التصور المقترح أن تواجهه بعض المعوقات التي يمكن أن نؤثر علي تنفيذه إلي حد ما، وتتمثل أهم تلك المعوقات فيما يلي: نقص أو ضعف الموارد المالية في المحافظات اللازمة لبر امج تأهيل مديري مدارس

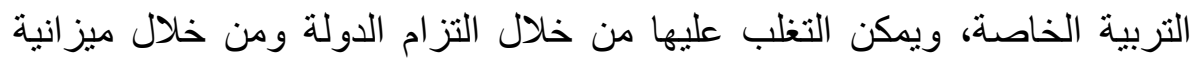


د. رجب أحمد عطا محمد

التربية والتعليم بتخصيص جزء كافي من ميزانية التعليم لمجال التربية الخاصة وخاصة تأهيل قيادات المدارس.

الجمود التظظيمي في مديريات و إدار ات التعليم بالمحافظات مما يسبب ضعف القدرة علي تغيير طريقة التنفيذ بسرعة، ويمكن التغلب عليها من خلال تصميم نظام

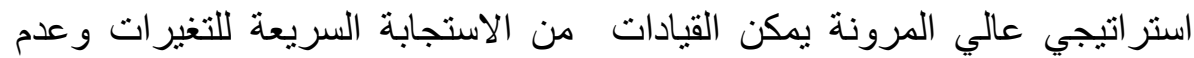
التعرض للمخاطرة غير المحسوبة من خلال تشجيع التفكير الاستر اتيجي لدي قادة مدارس التربية الخاصة في بر امج تأهيل و التنمية المهنية لمديري المدارس. قصور أنظمة وتفنية المعلومات بالأكاديمية المهنية للمعلمين ، ويمكن التغلب عليها من خلال حرص قيادات الأكاديمية المهنية للمعلمين علي جودة ودقة ذاكرتها التتظيمية حيت تمثل التغذية الراجعة لكل الممارسات و القرارات المتخذه، وتحتوي

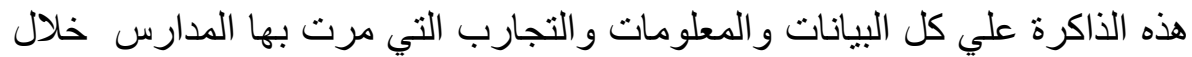

فترات عملها.

الخوف من كل ما هو جيد من أفكار أو أساليب عمل في مدارس التربية الخاصة، ويمكن التغلب عليها من خلال العمل علي تغيير ثقافة العمل داخل المدارس بحيث

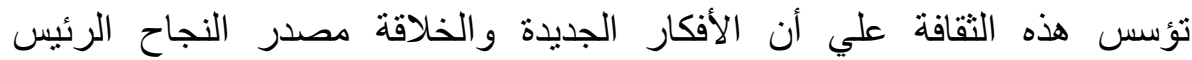
للمدارس، تشجع هذه الثقافة أعضاء المجتمع المدرسي من المبدعين والموهوبين القادرين علي اكتساب المعرفة الضمنية ودمجها بالمعارف والخبرات السابقة الظاهرة و الضمنية وتقديمها في صورة مخرجي الهات جديدة. عدم اقتناع القيادات في مديريات التربية والتعليم والوزارة بأهمية دور مديري

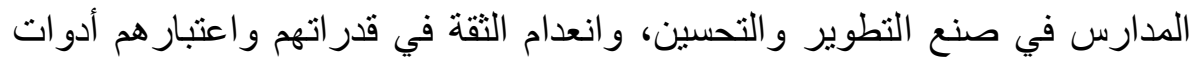

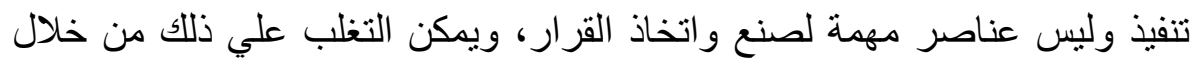
تحويل أدوار مديري المدارس من المهام الروتينية والتي تقتصر علي التنفيذ إلي

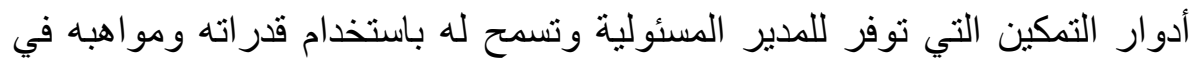
المشاركة في وضع وصنع السياسات والقرارات والخطط التعليمبة علي مستوي مديرية التربية والتعليم بالمحافظة، وتتيح له حرية التصرف وفي في إدارة المدرسة لتحقيق الأهداف التعليمية. 
تأهيل مديري مدارس التربية الخاصة بمحافظة البحر الأحمر في ضوء محددات الرشاقة الإستراتيجية

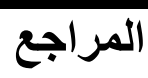

- إبر اهيم عصدت (Y . . Y).التنمية البشرية بالتعليم والتعلم في الوطن العربي، القاهرة ، دار الفكر العربي.

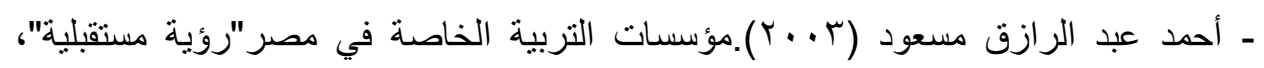
رسالة ماجستير غير منشورة، كلية التربية، جامعة طنطا.

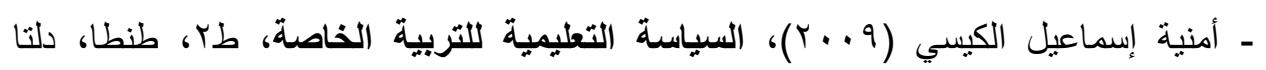
للطباعة والكمبيوتر و التصوير.

ـ أميرة أمين محمد دماج (9 (Y (Y)، دور الرشاقة الاستراتيجية في تحقيق الميزة التنافسية في

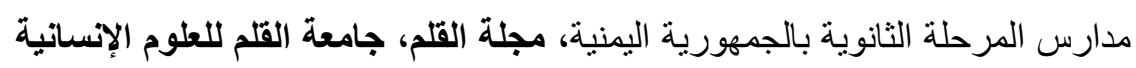

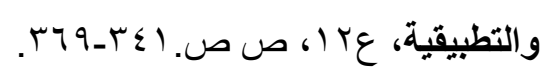

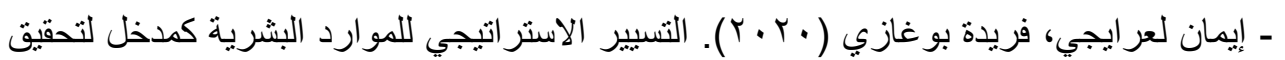

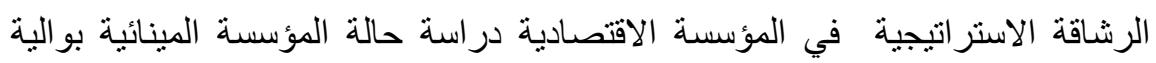
سكيكدة، مجلة الاستراتيجية والتنميـة، جامعة عبدالحميا بن باديس مستغانم - كلية

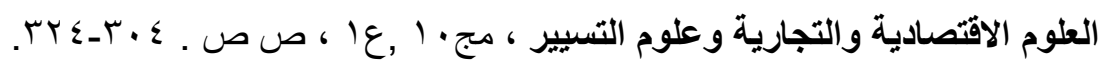

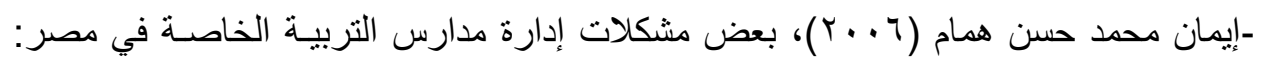
دراسة ميدانية علي محافظة الثرقية، رسالة ماجستير غير منشـورة، كلية التربية، جامعة الزقازيق.

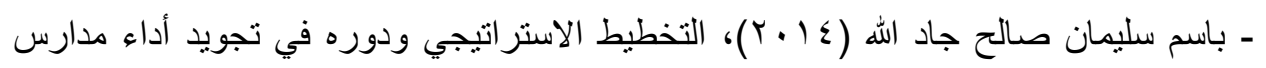
التربية الخاصة في صعيد مصر"دراسة ميدانية"، مجلة الدراسات الإنسانية

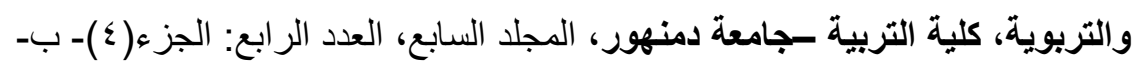

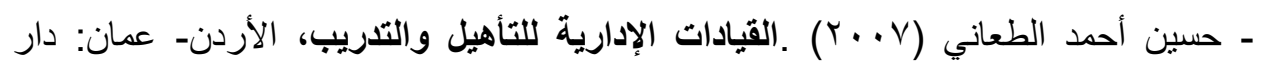
الميسرة.

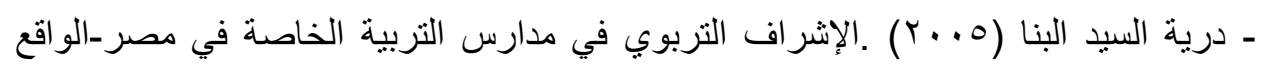

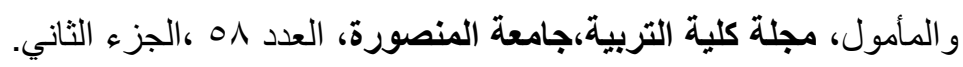


د. رجب أحمد عطا محمد

- رجاء سالم أبو مربغي، محمد سليم الزبون (Y (Y.) ـ تقدير الحاجات الإدارية التربوية لمديري مدارس التربية الخاصة في الأردن، دراسات العلوم التربوية،المجلد وس،

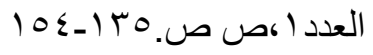

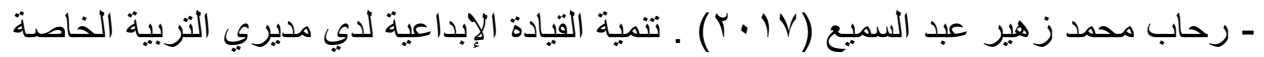
في ضوء مفهوم ثقافة الجودة ، رسالة دكتوراه ، كلية التربية ، جامعة بني سويف. -ريهام عبد الحميد علي شبيب (ع ( • ب). التمكين الإداري للقيادات العاملة في مجال التربية الخاصة بمصر تصور مقترح، رسالة ماجستير ، معهد الدراسات التربوية، جامعة القاهرة.

- سميحة محمد علي مخلوف (YV (Y). فعالية برنامج تدريبي مقترح لتحسين الأداء الإداري لدي مديري مدارس التربية الخاصة، مجلة التربية: جامعة الأزهر- كلية التربية،

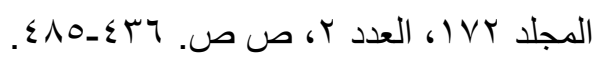

- شافي عوض ضيدان الرشيدي (T ( • ب).التمكين الإداري لمديري مدارس وفصول التربية الخاصة: مفاهيم، كفاياتهم، اختيار هم، المشكلات التي تواجهرم، عالم التربية: المؤسسة العربية للاستشارات العلمية وتنمية الموارد البشرية، المجلد VI، العدد

$$
\text { . I. }
$$

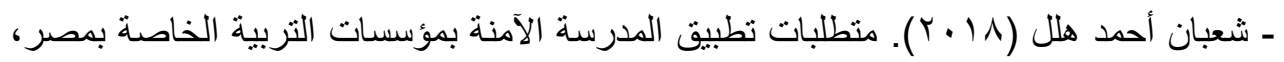
مجلة كلية التربية: جامعة المنوفية ، المجلد بس، العدد ب، ص ص. بrع-ـ

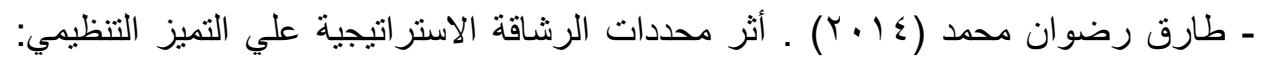
دراسة تطبيقية علي قطاع الاتصالات في مصر، مجلة التجارة والتمويل، كلية

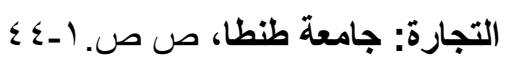

- عبد الرحمن سيد سليمان ، و إمبابي مراد محمد ( ج . . ؟). إدارة الإدارة والإشراف في التربية الخاصة، الرياض ، دار الز هر اء للنشر والتوزيع.

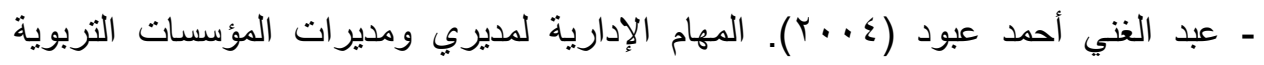
للأطفال ذوي الاحتياجات الخاصة، المؤتمر العلمي الثاني لمركز رعاية وتنمية 
تأهيل مديري مدارس التربية الخاصة بمحافظة البحر الأحمر في ضوء محدات الرشاقة الإستراتيجية

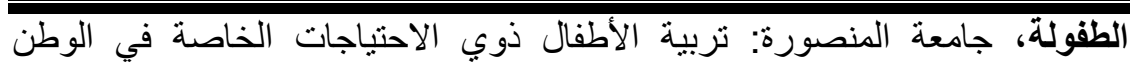

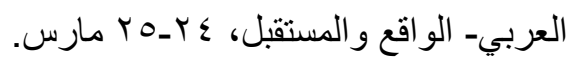

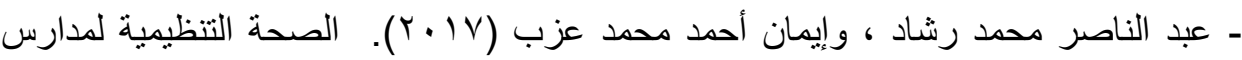
التربية الخاصة في مصر والرضا الوظيفي لمعلميها: دراسة تحليلية ، مجلة الإدارة

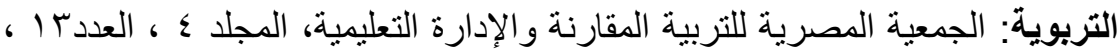

$$
.1 T r-10
$$

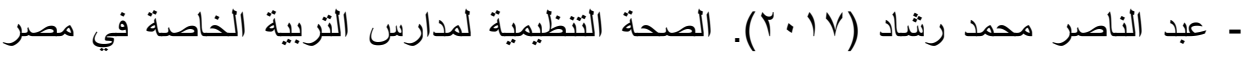

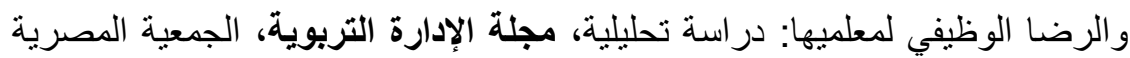

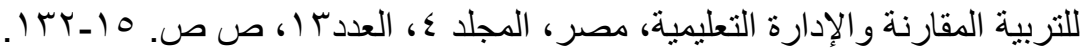

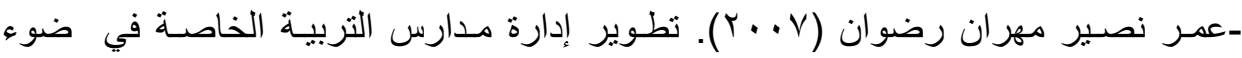
مدخل الإدارة الذاتية، رسالة ماجستير ، كليـة التربيـة، جامعـة عين شمس. - عنتر محمد أحمد عبد العال (Y (Y). منطلبات المعلومات لتحقق الرشاقة في الرشاقة بالجامعات المصرية جامعة سوهاج نموذجا، المجلة التربوية، كلية التربية -جامعة المعادية

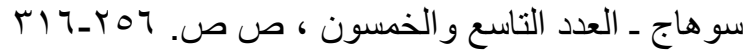

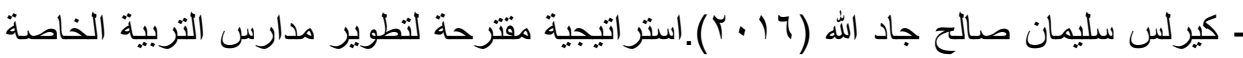

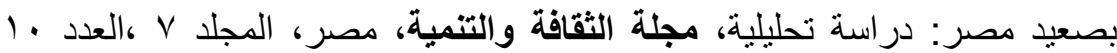

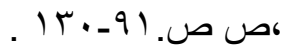
- متولي إبراهيم منولي (ع (ب). تقويم أداء مديري مدارس التربيـة السمعية في مصر

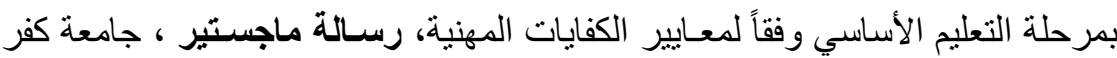

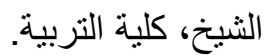
ـ محمد إبر اهيم عبدالغني عبد البر(ب ( ب): و اقع الإدارة الإليكترونية بمدارس التربية الخاصة



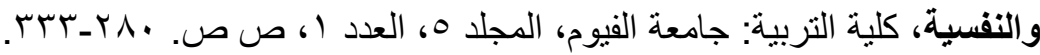


د. رجب أحمد عطا محمد

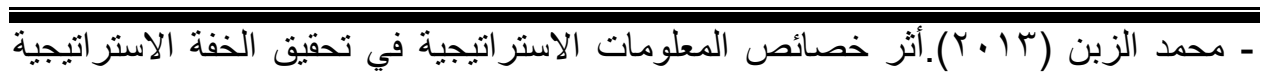
ودور القدرات التنافية كمتغير معدل -دراسة تطبيقية: على شركة ألبا هأوس في الأردن ."مجلة اتحاد الجامعات، المجلد 10،ص ص 9 اتـبس.

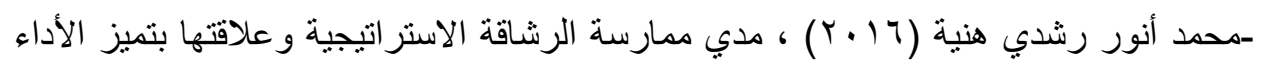
المؤسسي لدي قطاع الصناعات الغذائية في قطاع غزة، رسالة ماجستير ، كلية التجارة : الجامعة الإسلامية بغزة، فلسطين.

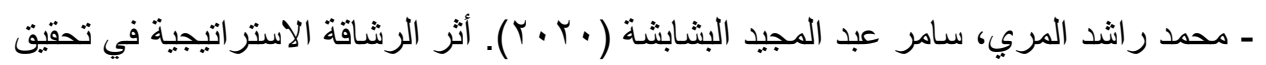
النجاح الاستراتيجي في البنوك التجارية القطرية، مجلة الزرقاء للبحوث والدراسات

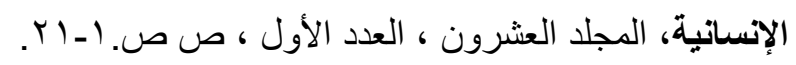

ـ محمد سرحان علي المحمودي (9 ( • (Y). مناهج البحث العلمي، الطبعة الثالثة، اليمن،صنعاء:

$$
\text { دار الكتب. }
$$

ـ محمد عبد الحميد محمد، محمد فتحي قاسم (T . ب).تطوير منظومة تدريب معلمي التربية الخاصة في مصر في ضوء خبرات بعض الدول، مجلة التربية، الجمعية المصرية

للتربية المقارنة و الإدارة التعليمية، السنة(V)، العدد( (I).

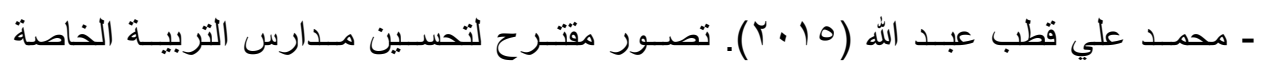
بمصر في ضوء الاتجاهات المعاصـرة، رسـالة ماجستير ، جامعة المنيا، كلية

$$
\text { التربية. }
$$

ـ مصطفي مختار السيد حسن (Y ( • Y). المشاركة المجتمعية في مدارس التربية الخاصة في بعض محافظات الصعيد " دراسة تحليلية"، رسالة دكتوراه، كلية التربية، جامعة

$$
\text { بورسعيد. }
$$

ـ منار محمد جابر (9 ( • (Y). الإبداع التنظيمي بمدارس التربية الخاصة المصرية في ضوء الإرجنوميكس: تصور مقترح، المجلة التربوية، كلية التربية: جامعة سوهاج، المجلد

$$
\text { 797_090.0 }
$$

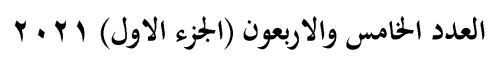

(255)

مجلة كلية التربية- جامعة عين شمس 
تأهيل مديزي مدارس التربية الخاصة بمحافظة البحر الأحمر في ضوء محددات الرشاقة الإستراتيجية

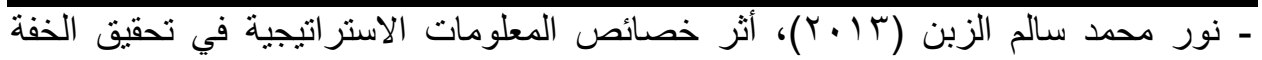

الاستراتيجية ودور القدرات التنافسية كمتغير معدل: دراسة تطبيقية علي شركة البا هاوس في الأردن، رسالة ماجستير ، جامعة الثرق الأوسط، الأردن.

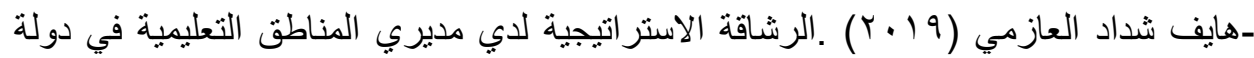
الكويت وعلاقتها بإعادة هندسة العمليات الإدارية من وجهة نظر العاملين فيها، رسالة ماجستير ، كلية الدراسات العليا: جامعة مؤتة، الأردن.

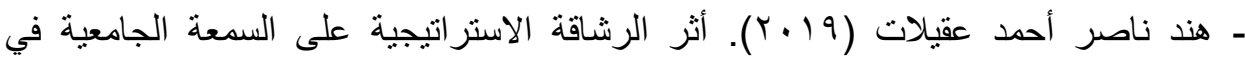

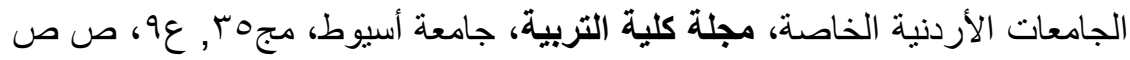
$.7 T V-T \leqslant T$.

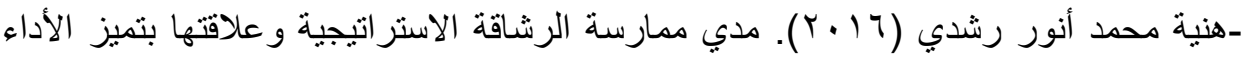

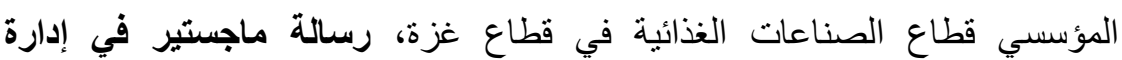
الأعمال، كلية التجارة، الجامعة الإسلامية، غزة.

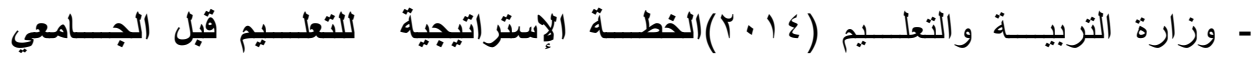

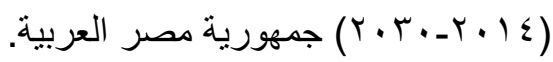

- وزارة التربية والتعليم، التوجيهات الفنية والتعليمية والإدارية لمدارس وفصول التربهابة التربية

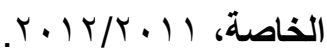

- Atallah Mohammed Tayser Alsharah (2020), Impact of Strategic Agility Determinants and Dimensions on Institutional Performance Excellence in Government Institutions in the Hashemite Kingdom of Jordan, International Journal of Business Administration, 11(5), pp.29-43.

- Ade Oyedijo. (2012). Strategic Agility and Competitive Performance in the Nigerian Telecommunication Industry: An Empirical Investigation. American International Journal of Contemporary Research, 2(3), pp30-37. 
د. رجب أحمد عطا محمد

- Ali Bin Abdulreaha Al Lawati (2018). Competencies of Schools' Principals in the Sultanate of Oman and their Predictive Variables, International Journal of Learning Management Systems,6(2), pp.75-92.

- Arbussa, A., Bikfalvi, A., \& Marquès, P. (2017). Strategic agilitydriven business model renewal: the case of an SME. Management Decision, 55(2), 271-293. https://doi.org/10.1108/MD-05-2016-0355.

- Arokodare, M. A. \& Asikhia, O. U(2020).Strategic Agility:

Achieving Superior Organizational Performance through

Strategic Foresight, Global Journal of Management and Business Research, 2(3),pp.7-16.

- Arokodare, M. A., Asikhia, O. U., \& Makinde, G. O (2019).Strategic Agility and Firm Performance: The Moderating Role of Organizational Culture, Business Management Dynamics,9(3), September, pp. 1-12.

- Bella Butler, Kayla Surace (2015).Call For Organisational Agility In The Emergent Sector Of The Service Industry, Journal of Business Management, No.10 ISSN 1691-5348,pp.1148.

- David Teece, Margaret Peteraf and Sohvi Leih.(2016). Dynamic capabilities and organizational agility: Risk, uncertainty, and strategy in the innovation economy, California Management Review, 58(4), 13- 35. 
تأهيل مديني مدارس التربية الخاصة بدافظة البحر الأحمر في ضوء محدات الرشاقة الإستراتيجية

- DiPaola, M. F., Walther-Thomas, C. (2003). Principals and special education: The critical role of school leaders, Center on Personnel Studies in Special Education (COPPSE Document No. IB-7). Gainesville, FL: University of Florida,pp.3-28.

- Divesh Ojha. (2008). Impact of Strategic agility on competitive capabilities and financial performance.USA: (Unpublished PhD Thesis). Clemson University.

- Donald Sull. (2009). How to Thrive in Turbulent Markets. Harvard Business Review, 87(2), 78-88.

- Francesco Debellis, et al (2020), Strategic agility and international joint ventures: The willingness-ability paradox of family firms, Journal of International Management, Available $\begin{array}{lllll}\text { online } 6 & \text { February } & 2020, & 100739 \text {, }\end{array}$ https://doi.org/10.1016/j.intman.2020.100739.

- khoshnood \& Nematizadeh (2017 )."Strategic Agility and Its Impact on the Competitive Capabilities in Iran Private Banks, International Journal of Business and Management,12(2); pp.220-229.

- Kohtamäki . Marko \& Farmer. Donald,(2017). Strategic AgilityIntegrating Business Intelligence with Strategy, University of Vaasa. Finland. DOI 10.1007/978-3-31954846-3_2.

- Long, C. (2000). Measuring Your Strategic Agility, Consulting to Management C2M,11(3), 25-37. 
د. رجب أحمد عطا محمد

- Maarit Santala.(2009). Strategic Agility in a Small Knowledge Intensive Business Services Company: Case Swot Consulting, Master's thesis, Department of Marketing and Management, Helsinki School Of Economics, Espoo Finland.

- Mary Yoko Brannen \&Yves Doz. (2012). Corporate Languages and Strategic Agility. California Management Review, 54(3), 77-97.

- Muhammad K. Hamdan, et.al(2020).The Reality of Applying Strategic Agility in Palestinian NGOs, International Journal of Academic Multidisciplinary Research (IJAMR), 4( 4), April, pp. 76-103.

- Narendra Kumar. (2017, December 21). The Four Keys You

Need know To Achieve Strategic Agility. Retrieved Nov 6 , 2020, from Enterslice:

https://enterslice.com/learning/know-achieve-strategicagility/.

- Nikoo Tabe Khoshnood \& Sina Nematizade (2017). Strategic Agility and Its Impact on the Competitive Capabilities in Iranian Private Banks, International Journal of Business and Management; 12, (2);pp.220-229.

- Onyema .E. Ofoegbu \& Paul Ayobami Akanbi (2012). The influence of strategic agility on the perceived performance of manufacturing firms in Nigeria. The International Business \& Economics Research Journal,.11,( 2),pp. 153-169. 
تأهيل مديري ددارس التربية الخاصة بحافظة البحر الأحمر في ضوء محدات الرشاقة الإستراتيجية

- Radwan, Tariq (2014). The effect of the determinants of strategic agility on organizational excellence: an applied study on the telecommunications sector in Egypt, Trade and Finance Journal: Tanta University, 1 (3) 225-232..

- René Rohrbeck \& Menes Etingue Kum (2018). Corporate foresight and its impact on firm performance: A longitudinal analysis. Technological Forecasting and Social Change,Vol. 129,pp. 105-116.

- Rick Dove. (2001). Response Ability: The Language, Structure, and Culture of the Agile Enterprise. New York, NY: John Wiley \& Sons

- Robert E. Morgan \& Kelly Page.(2008), Managing Business Transformation to Deliver Strategic Agility, Strategic Change, 17 ( 5/6), p155-168..

- Samer Abu-Radi. (2013). Strategic Agility and Its Impact on the Operations Competitive Capabilities in Jordanian Private Hospitals (Unpublished Master Thesis). Middle East University, Jordan.

- Sampath, J. M. (2015). Exploring the significance of strategic agility in building sustainable competitive advantage for retail banks in India. Working Paper Series No.ST-1601.SVKM's Narsee Monjee Institute of Management Studies, School of Business Management, deemed University. 
- Wadhwa, S., \& Rao, K. S. (2003). Flexibility and agility for enterprise synchronization: Knowledge and innovation management towards flexagility, Studies in Informatics and Control, 12(2), 111-128..

- Yves Doz \& Mikko Kosonen. (2008). Fast Strategy: How strategic agility will help to stay ahead of the game, Harlow: United Kingdom.

- Yves Doz \& Mikko Kosonen. (2008). the Dynamics of Strategic Agility: Nokia's Rollercoaster Experience. California Management Review,50(3),130-145.

- Yves Doz \& Mikko Kosonen. (2010). Embedding strategic agility: a leadership agenda for accelerating business model renewal. Long Range Planning, 43(2-3), 370-382. https://doi.org/10.1016/i.Irp.2009.07.006. 
تأهيل مديزي مدارس التربية الخاصة بمحافظة البحر الأحمر في ضوء محددات الرشاقة الإستراتيجية

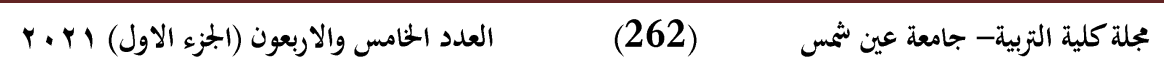

